\title{
ANALYSIS OF THE SCOPE OF ENERGY SUBSIDIES AND SUGGESTIONS FOR THE G-20 INITIATIVE
}

\author{
IEA, OPEC, OECD, WORLD BANK \\ JOINT REPORT \\ Prepared for submission to the \\ G-20 Summit Meeting \\ Toronto (Canada), 26-27 June 2010
}

16 June 2010

This Joint Report does not necessarily express the positions of the member countries of IEA, OECD and the World Bank, and those of OPEC and of the Governments it represents. IEA, OPEC, OECD, and the World Bank assume no liability or responsibility whatsoever for the use of the data or analyses contained in this Joint Report and nothing in this Joint Report shall be construed as interpreting or modifying any legal obligations under the WTO Agreements, treaty, law or other texts; or expressing any legal opinions or having probative legal value in any proceedings. 


\section{Table of Contents}

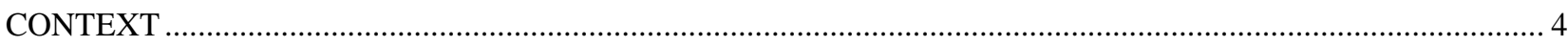

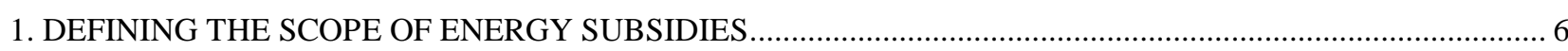

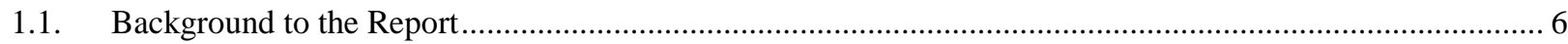

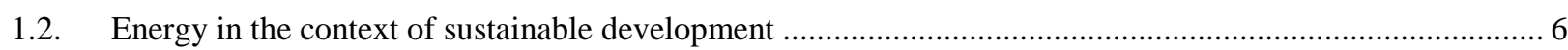

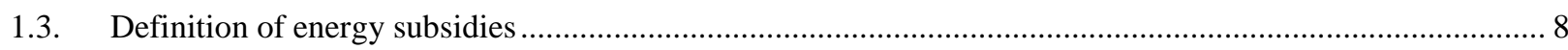

1.4. What makes for inefficient subsidies leading to wasteful consumption? ………........................................ 8

1.5. Understanding social and economic cost-benefit analysis of energy subsidies ........................................... 9

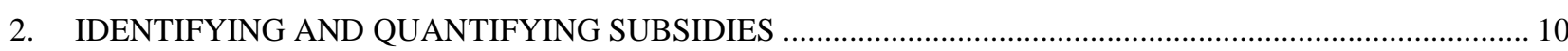

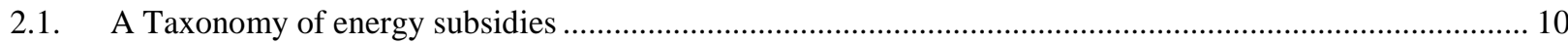

2.1.1. Overview of the mechanisms by which sectoral support is provided .................................................. 10

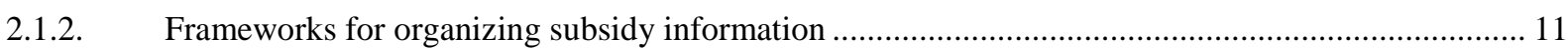

Table 2.1 Matrix of transfers, with examples of specific support policies ............................................................ 12

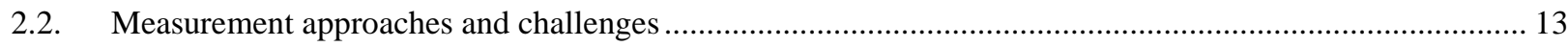

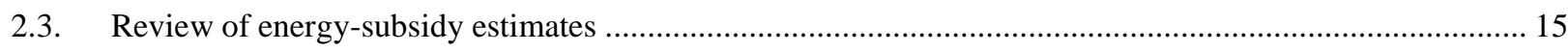

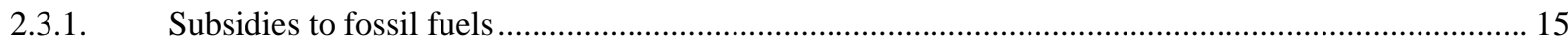

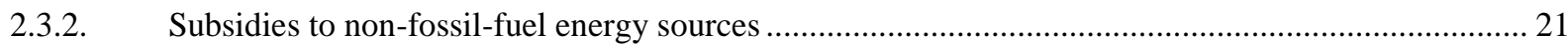

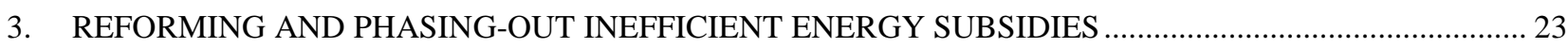

3.1. Impact of inefficient energy subsidies and subsidy reform on sustainable development ............................. 23

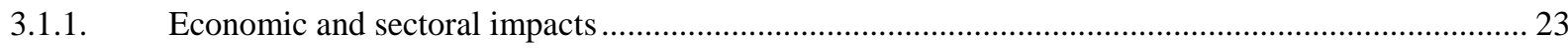

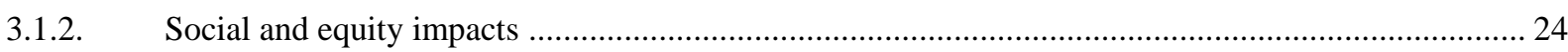

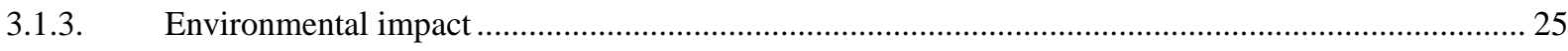

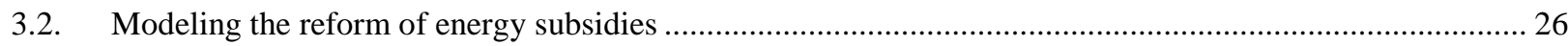

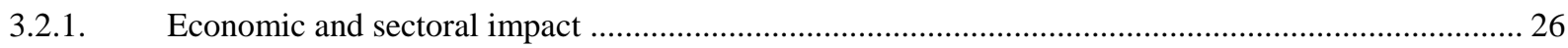

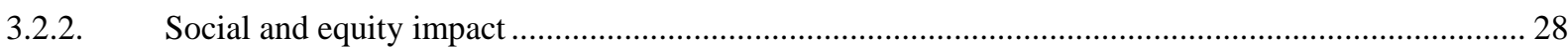

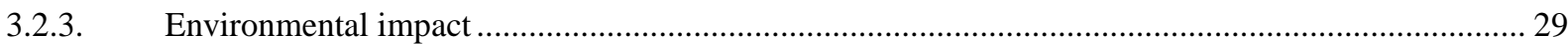

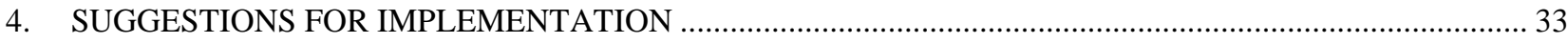

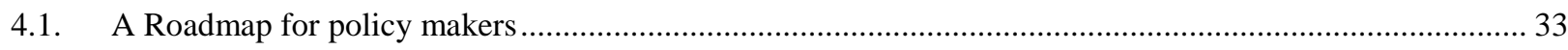

4.2. The Political Economy of Phasing out Inefficient Energy Subsidies ......................................................... 35

4.3. Policy Tools to Address Distributional Issues ........................................................................................... 37

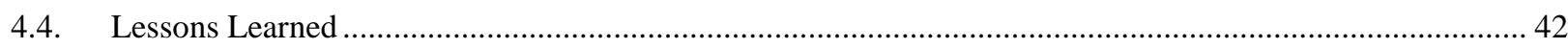

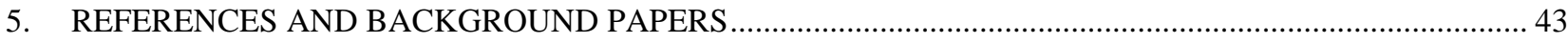




\section{LIST OF ANNEXES}

ANNEX 1: CASE STUDY ON GLOBAL BIOFUELS (PREPARED BY OPEC)..... 51

ANNEX 2: SUBSIDIES ON ELECTRICITY, LPG \& KEROSENE IN COUNTRIES WITH LOW LEVELS OF MODERN ENERGY ACCESS (PREPARED BY IEA)

ANNEX 3

- SELECTED CASE STUDIES IN OECD AND NON-OECD COUNTRIES (PREPARED BY THE

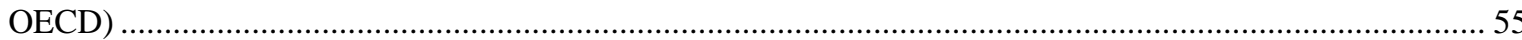

- $\quad$ GENERAL EQUILIBRIUM ANALYSIS: EGYPTIAN CASE STUDY (PREPARED BY OPEC) ............. 70

- A SENEGAL CASE STUDY (PREPARED BY OPEC) …………………………………………......... 71

- CASE STUDIES EVIDENCE FROM DEVELOPING COUNTRIES (PREPARED BY THE WORLD BANK)

ANNEX 4: THE IMPACT OF ENERGY SUBSIDIES REMOVAL ON THE POOR (PREPARED BY THE WORLD BANK) 80

\section{LIST OF BACKGROUND PAPERS}

OECD Secretariat. 2010. "Measuring Support to Energy - Version 1.0", OECD Background Paper, OECD, Paris, available at www.oecd.org/g20/fossilfuelsubsidies

Burniaux, Jean-Marc and Jean Chateau. 2010. "An Overview of the OECD ENV-Linkages Model”, OECD Background Paper, OECD, Paris, available at www.oecd.org/g20/fossilfuelsubsidies 


\section{Context}

- Subsidies are one of many policy instruments used by governments to attain economic, social and environmental objectives. Worldwide, subsidies exist in several economic sectors, including agriculture, fisheries and energy. Governments can subsidize consumption and production by transferring funds to recipients directly, by assuming part of their risk, by selectively reducing or increasing the taxes they would otherwise have to pay, and by imposing mandates and barriers to trade.

- Energy subsidies, in particular, are often used to alleviate energy poverty and promote economic development by enabling access to affordable modern energy services. Given the critical role that energy plays in economic and social development, the reform of inefficient energy subsidies should be analyzed in a context, including their links to the three pillars of sustainable development, including economic growth, poverty reduction and environmental dimensions. Taking into account the sovereign rights of countries to develop economic and social policies, subsidies are fundamentally country-specific, and should be based on national circumstances.

- There is no systematic reporting of energy subsidies at the international level. There are also gaps and limitations in the measurement and estimation currently available for energy subsidies at the global level.

- Using the price-gap methodology, the IEA estimates that fossil-fuel-related consumption subsidies amounted to US\$ 557 billion in 2008 (IEA, 2010). ${ }^{1}$ Based on IEA analysis, if these subsidies were phased out by 2020 it would result in a reduction in primary energy demand at the global level of $5.8 \%$ and a fall in energy-related carbon-dioxide emissions of $6.9 \%$, compared with a baseline in which subsidy rates remain unchanged.

- However, it is worth noting that the price-gap methodology has shortcomings. OPEC is of the opinion that the benchmark price to be used in the case of energy resource well-endowed countries should be the cost of production. Consequently, OPEC could not associate itself with the above estimation of fossil-fuel-related consumption subsidies.

- Furthermore, subsidies provided to producers of fossil fuels may be on the order of US\$ 100 billion per year (GSI, 2009). The total order of magnitude of subsidies to consumers and producers - almost US\$ 700 billion a year - is roughly equivalent to $1 \%$ of world GDP (World Bank, 2009; OECD, 2008a). Energy subsidies also imply significant fiscal and quasi-fiscal costs (Ebinger, 2006; Briceno et al., 2009).

- OECD countries have been raising taxes (negative subsidies) on energy, mainly fossil transport fuels, in amounts exceeding US\$ 400 billion (excluding Goods and Services Tax and Value Added Tax) in each of the years between 2003 and 2008; these taxes significantly affect relative end-use prices for fuels. ${ }^{2}$

- Subsidies to other non-fossil-fuel energy are considerable and have been increasing over time. A rough estimate by the Global Subsidies Initiative (GSI) indicates around US\$ 100 billion per year are spent to subsidize alternatives to fossil fuels. Based on this, OPEC estimates that renewable energy sources and biofuels are subsidized at a much higher rate than fossil fuels. The per unit basis subsidies to renewables and biofuels are equal to US cents 5.0 per $\mathrm{kWh}$, compared with US cents 1.7 per $\mathrm{kWh}$ for nuclear power, and US cents 0.8 per $\mathrm{kWh}$ for fossil fuels.

1 The IEA is currently compiling estimates for consumption subsidies for 2009. The full time series from 2007 to 2009 will be finalized before the end of 2010 .

2 Source: OECD/EEA database on instruments used for environmental policy (www.oecd.org/env/policies/database) 
- To put these estimates into perspective, estimated agriculture subsidies in OECD countries were close to US\$ 400 billion in 2008 (OECD, 2009a). Government financial transfers to marine capture fisheries provided by OECD countries are estimated to be US\$ 6 billion a year (OECD, 2006a).

- The value of petroleum subsidies to consumers increased dramatically in recent years, largely as a result of rising oil prices, but has been projected to decline to US\$240 billion in 2010 (Coady et al., 2010). The increase in petroleum subsidies from 2003 to mid 2008 was particularly strong and consistent over time (IMF, 2008; Coady et al., 2010). From end-2008 to mid-2009, global subsidies are projected to increase from the lowest annual rate of US\$50 billion to almost US $\$ 140$ billion, reflecting the high volatility of oil prices.

- Poorly implemented energy subsidies are economically costly to taxpayers and can damage the environment through increased emissions of greenhouse gas and other air pollutants. Recent OECD and IEA analyses indicate that phasing-out fossil fuel subsidies could lead to a $10 \%$ reduction in global greenhouse-gas emissions in 2050 compared with business-as-usual (OECD, 2009b; OECD 2010a). Several studies reviewed by the Independent Evaluation Group (IEG) of the World Bank (IEG, 2009) found that subsidies to fossil fuel use tend to benefit high-income households more than the poor, due to the former's higher consumption levels. According to the same study, the bottom $40 \%$ of the population in terms of income distribution received only $15-20 \%$ of the fuel subsidies in developing countries. Nonetheless, some subsidies related to fossil fuels can improve the environment or the welfare of the poor if they encourage reduced reliance on biomass in areas at risk of deforestation, and fund research into ways to sequester carbon emissions from combustion.

- Should subsidy phase-out be justified on the grounds of climate change mitigation objectives, then the provisions of the United Nations Framework Convention on Climate Change (UNFCCC) should apply, in particular the principles of equity, and common but differentiated responsibilities and respective capabilities, as well as the provision that "economic and social development and poverty eradication are the first and overriding priorities of the developing country Parties".

- The report also provides a roadmap to guide policy makers, based on lesson drawn from case studies in developed and developing countries. A necessary first step in implementing reforms is identifying those subsidies that are inefficient and lead to wasteful consumption, based on the decision tree proposed by the World Bank.

- Particular attention needs also to be devoted to address implementation challenges, including overcoming political obstacles and affordability constraints and to facilitate the reform process through the use of targeted assistance, safety-nets and industrial restructuring packages.

- Since it may take time to put in place effective social safety nets, governments may want to consider options for assisting the transition of the poor, including temporarily maintaining universal subsidies on those fuels that are better targeted to the poor and are more important in their household budgets and introducing short-term measures to alleviate the impact of tariff increases on the poor, using where possible volume differentiated tariffs or connection charge subsidies. 


\section{Defining the Scope of Energy Subsidies}

\subsection{Background to the Report}

1. When the G-20 Leaders met on 24-25 September 2009 in Pittsburgh, USA, they agreed in their Communiqué that, building on the efforts of many countries to "reduc[e] fossil fuel subsidies while preventing adverse impact on the poorest", they were committed to "rationalize and phase out over the medium term inefficient fossil fuel subsidies that encourage wasteful consumption". Recognizing "the importance of providing those in need with essential energy services, including through the use of targeted cash transfers and other appropriate mechanisms", they called on:

- individual countries to "phase out such subsidies worldwide" and for Energy and Finance Ministers of G-20 countries to develop their country implementation strategies and timeframes and report back to the next G-20 Summit. The call to phase out fossil-fuel subsidies is directed at all nations that subsidize fossil fuels, not only at the G-20 countries themselves, taking into account the specific circumstances of each economy. The Institutions "tasked" by the G-20 Communiqué (bullet below) were called to stand ready to offer support to countries in this process;

- the IEA, OPEC, OECD, and World Bank to provide an analysis of the scope of energy subsidies and suggestions for the implementation of this initiative, and report back at the next summit in June 2010.

2. This draft report has been developed jointly by the IEA, OPEC, OECD and World Bank in response to this request. It draws on the relevant expertise and work of the four tasked organizations, but also on input and comments from other organizations and experts. The report includes:

- Discussion of the scope of energy subsidies;

- Estimates of energy subsidies, and identification of the gaps in the existing data and issues around the measurement of energy subsidies;

- Modelling-based analysis of the implications of phasing-out energy subsidies on the economy, including socio-economic and trade impacts, the environment, and the energy sector; and

- Suggestions for the implementation of phase-out of inefficient subsidies leading to wasteful consumption, drawing on country case studies, including discussion of how to address social impacts.

\subsection{Energy in the context of sustainable development}

3. Energy is critical to economic development and poverty reduction. It is a vital input to all sectors of the economy, fuelling transport to move goods and people and providing electricity to industry, commerce, agriculture, and important social services such as education and health. Energy is an essential catalyst for economic growth and improving standards of living, yet access to modern energy services remains an elusive goal for the 1.5 billion people that lack access to electricity services (IEA, 2009). Some $85 \%$ of those people live in rural areas. Even though more than 1 billion people have gained access to electricity over the last 20 years as many people again remain without access. There are large variations in electrification rates across and within regions. OECD and transition economies have close to universal access. By contrast, South Asia has an electrification rate of $60 \%$ and Sub-Saharan Africa only 29\%. Sub-Saharan Africa also has, by far, the lowest urban access rate: 58\%. IEA analysis indicates that universal electricity access could be 
achieved with additional investment of US\$ 35 billion per year in 2008-2030 - or annual investment equivalent to just 6\% of global spending on fossil-fuel consumption subsidies in 2008.

4. Nearly 2.5 billion people continue to use traditional biomass fuels for cooking and heating (IEA, 2009). Yet without improved access to clean fuels to cook food, boil water and support productive activities, several of the millennium development goals (MDGs) - notably the goal of poverty eradication-are likely to be compromised.

5. Given the critical role that energy plays in economic and social development, the reform of inefficient energy subsidies should be analyzed in context, including their links to each of the economic, social and environmental dimensions of sustainable development. The challenge is to meet the needs of countries and people for access to affordable modern energy services, and also to tackle climate change and other forms of pollution in order to protect the environment, bearing in mind the principles of equity, common but differentiated responsibilities, and developing countries' overriding priorities of economic growth, social progress and poverty eradication.

6. Governments support the production or consumption of energy in many ways: by keeping prices low with subsidies, increasing prices through taxation; providing grants or lowinterest loans, or guaranteeing loans provided by commercial banks; granting tax exemptions or reductions; providing certain companies with preferential access to mineral resources or land (e.g., for pipelines or transmission lines) at below-market prices; and supporting research and development related to particular energy sources, as in the case of renewables (Box 1.1).

7. The sets of policies that countries have used to influence their energy markets vary according to their level of development. Developed countries have generally relied on regulatory instruments and taxes or tax preferences, supplemented by support for capital formation in the sector and R\&D and raw materials, whereas developing countries have often used interventions that reduce the prices of energy to consumers. Most G20 countries apply taxes (negative subsidies) on gasoline and diesel. Based on IEA price and tax data, OPEC estimates that in some countries, including GST and VAT, these represented up to 60\% for gasoline and 55\% for diesel of the enduser price in the five-year period from 2003 to 2008.

\section{Box 1.1 Energy Subsidies Supporting Renewable Energy}

Countries around the world rely on a range of mechanisms to promote the diffusion of renewable forms of energy. These include feed-in tariffs, national targets and quotas, capital grants, investments or other tax credits, tax exemptions and energy-production payments.

These are not only used in OECD countries. A number of developing countries (such as Brazil, China, Turkey Argentina and Philippines) have introduced feed-in tariffs. While a few (China, Chile, India and Philippines) have embarked on renewable portfolio standards or tradable certificates, none have introduced carbon pricing.

In addition, the expansion of the biofuels industry in OECD countries has required substantial public support. In the US, biodiesel is subsidized at a rate of more than US 50 cents/liter. Globally, subsidies on biofuels are estimated to be around US\$ 20 billion in 2008 despite increasing concerns over biofuels' sustainability and impacts on food supply and security (see Annex 1 prepared by OPEC).

Despite these efforts, renewable energy still only represents $5 \%$ of global power capacity and $3.4 \%$ of power generation. Further, these schemes may not be the most efficient policy tools. While more difficult to implement, penalizing polluters, e.g. through internalization of external costs, would be a better approach.

Source: REN21, 2009, GSI (2010) and IEF (2010). 


\subsection{Definition of energy subsidies}

8. Finding a commonly agreed definition of subsidies has proven a major challenge in the G-20 context and countries have decided to adopt their own definition of energy subsidies. All energy subsidies are considered within the scope of the report. Additional focus is given to inefficient fossil-fuel subsidies that lead to wasteful consumption, given that the tasked organizations were also requested to provide, in addition to analysis of the scope of energy subsidies, suggestions for implementation of the G-20 initiative.

9. The WTO Agreement on Subsidies and Countervailing Measures (ACMS) provides a definition of "subsidy" that has been accepted by all WTO members. Article 1 of the Agreement states that a "subsidy" exists when there is a "financial contribution" by a government or public body that confers a "benefit". A "financial contribution" arises where: (i) a government practice involves a direct transfer of funds (e.g. grants, loans, and equity infusion), potential direct transfers of funds or liabilities (e.g. loan guarantees); (ii) government revenue that is otherwise due is foregone or not collected (e.g. fiscal incentives such as tax credits); (iii) a government provides goods or services other than general infrastructure, or purchases goods; or (iv) a government entrusts or directs a private body to carry out one or more of the above functions. A "benefit" is conferred when the "financial contribution" is provided to the recipient on terms that are more favorable than those that the recipient could have obtained from the market.

10. The practical applicability of the WTO definition in generating data of energy subsidies has proven to be limited. Many factors contribute to this, including lack of commitment and transparency of countries in reporting energy subsidies. In addition, energy subsidies other than direct subsidies are difficult to estimate, hence to monitor on a cross-country, large-scale basis.

\subsection{What makes for inefficient subsidies leading to wasteful consumption?}

11. Policy makers usually justify energy subsidies with the argument that they contribute to economic growth, poverty reduction and enhance security of energy supply. And it is indeed true that judicious use of energy subsidies can help address market failures or respond to social and distributional objectives, especially where social welfare mechanisms for directly providing income support to the poor do not exist. Subsidies can be critical for ensuring access to modern energy services, including electricity, for the poorest (Komives et al. 2005 and 2007). In addition, well-designed and targeted subsidies can overcome market failures by mitigating environmental problems in specific contexts, for example by encouraging alternatives to biomass in areas where deforestation is an issue. ${ }^{3}$

12. Energy subsidies could create distortive price signals and result in higher energy consumption or production, or barriers to entry for cleaner energy services. Subsidies to consumption, by lowering end-use prices, can encourage increased energy use and reduce incentives to conserve energy efficiently. Thus, former Soviet Union, where electricity prices are much lower than their cost, are characterized by very high consumption per capita and lowest energy efficiency (Sterner, 2007). Similarly, production subsidies can promote the consumption of one type of fuel over another, by reducing the cost of the input for energy service providers. This type of policy has often been applied in the past to the coal used to produce electricity in eastern and central Europe, and in many developing countries, including China and India, and is also currently applied for renewable energy, including biofuels in numerous countries around the world. Despite many mine closures, coal subsidies still amount to billions of dollars a year in OECD countries (the case studies 3 prepared by OECD included in Annex 3 discuss the different approaches used in a variety of European countries to remove coal subsidies).

3 The implicit subsidy of biomass is due to the difficulties of pricing biomass and its environmental damage costs. Namely, the use of biomass for cooking and heating results in indoor air pollution. 
13. Energy subsidies can put societies onto inefficient consumption and production paths. Fossil-fuel subsidies to consumers can create dependencies and discourage users from shifting to cleaner sources of energy. Similarly, subsidies to specific energy technologies undermine the development and commercialization of other technologies that might ultimately become more economically (as well as environmentally) attractive. As such, subsidies can "lock-in" technologies to the exclusion of other, more promising ones.

14. Identifying which specific fossil-fuel subsidies are "inefficient" and "encourage wasteful consumption" requires understanding the circumstances of each country, and the impact of the different subsidies in use. As such it remains in the remit of sovereign decision making. Acknowledging that a particular energy subsidy affects the production or consumption of a fossil fuel does not automatically mean that it is inefficient or leads to wasteful consumption. How a subsidy is designed and administered, and especially how it interacts with other government policies, determines to what extent they are socially and environmental harmful and the urgency to phase it out. Chapter 4 proposes a methodology to do so, based on social cost-benefit analysis (which is introduced in the next section) and the impact of subsidies on consumption, whose modeling is presented in Chapter 3.

\subsection{Understanding social and economic cost-benefit analysis of energy subsidies}

15. Examining energy subsidies in a broad development perspective requires a methodology, such as social cost-benefit analysis (SCBA) that evaluates the impacts of energy subsidy changes on social welfare. SCBA permits a socio-economic evaluation of change in policy or regulatory arrangement, identifying, measuring and then discounting future costs and benefits to enable the calculation of the net economic worth of particular policy options. An example of how it can be used to examine the social, economic and environmental impacts of energy subsidies is offered in Fig. 1.1.

Fig. 1.1 Social, Economic, and Environmental Impacts of Energy Subsidies (UNEP)

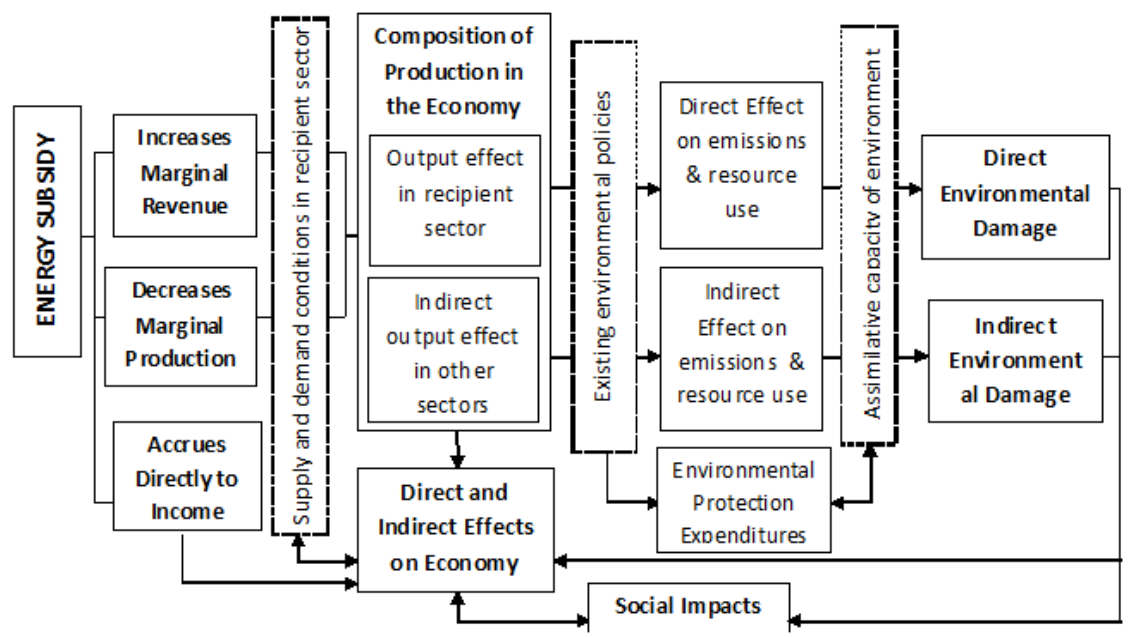

Source: adapted from UNEP (2004)

16. SCBA permits a socio-economic evaluation of changes in policies or regulatory arrangements identifying, measuring and then discounting future costs and benefits to present values to enable the calculation of the net economic worth of a policy option. SCBA is a decision standard that is used commonly by policymakers to assist in determining whether a policy should 
be implemented. ${ }^{4}$ SCBA monetizes the effects of a policy on individuals or groups in order to facilitate comparisons with the status quo or with other alternative policies. Loosely speaking, SCBA justifies a decision or regulatory change when the gains to groups (or individuals) resulting from the change exceed the losses to other groups (or individuals). The criterion that is considered in modern SCBA for justifying a policy change is that those who are better off from the policy change gain enough to potentially compensate those who are less well off.

17. The costs and benefits considered by SCBA are not limited to easily quantifiable changes in material goods, but should be construed in their widest sense, measuring changes in individual utility and total social welfare. While the costs and benefits may relate to goods and services that have a simple and transparent measure in a convenient unit (e.g. prices in monetary terms), this is frequently not the case, in particular in terms of the social or environmental impacts. As such, a number of empirical studies have used computable general equilibrium (CGE) models to model some elements of the welfare impact of the removal of energy subsidies (see Annex 3prepared by OECD, OPEC and World Bank and Annex 4 prepared by the World Bank).

\section{Identifying and quantifying subsidies}

18. Estimates of subsidies based on a robust methodology can be of enormous value for policy analysis. The data can serve as an input into modeling to assess the effectiveness and efficiency of policies in delivering the outcomes for which they were designed and to understand their effects on production, trade, income, the environment, and so forth. Consistent and comparable subsidy estimates allow countries to measure their progress in rationalizing and phasing-out inefficient energy subsidies that encourage wasteful consumption.

19. The following proposes a taxonomy of energy subsidies, describes briefly how different types of subsidies are measured, and reviews the available information on energy subsidies.

\subsection{A Taxonomy of energy subsidies}

\subsubsection{Overview of the mechanisms by which sectoral support is provided}

20. Governments support consumption and production in numerous ways: by intervening in markets in such a way as to affect costs or prices, by transferring funds to recipients directly, by assuming part of their risk, by selectively reducing the taxes they would otherwise have to pay, and by undercharging for the use of government-supplied goods or assets. Often, more than one transfer mechanism is used. For example, on the consumption side, a government may provide tax breaks to purchasers of motor vehicles and at the same time regulate the price of transport fuels below the international market price or even below the cost of producing the fuels. Similarly, on the production side, a government may fund research at a national laboratory on how to convert coal into a liquid transport fuel, provide grants and loan guarantees to companies investing in synthetic fuels from coal, provide a tax credit linked to the production of such fuels, and exempt

$4 \quad$ There are many standard frameworks for cost benefit analysis, such as the, "Benefit-Cost Analysis Guide 1998, Treasury Board of Canada Secretariat", and the "Cost Benefit Analysis Procedure Manual 2007 by the Australian Government". Cost-benefit analysis (CBA) is a powerful analytical tool and has been gaining importance in assessing and quantifying the impacts of investment projects and policy changes (OECD, 2006). It is increasingly used in projects and policy evaluation in OECD and non-OECD countries. This is particularly the case in Australia, North America, the UK, and the Nordic countries, where deciding on large investment projects and implementing policies with significant expected impacts requires a thorough CBA to ensure that resources are effectively allocated. 
such producers ${ }^{5}$ from paying royalties on coal mined from state-owned lands. The national government may, in turn, pay the producer a higher price for the fuel than it could have paid for an imported, petroleum-derived fuel. For biofuels, in addition to mandatory targets, import tariff and tax exemption for producers, support is also provided through agriculture subsidies to raw materials.

21. The effects of subsidies depend not only on how governments subsidize but also on what economic variables they subsidize - i.e., consumer or producer prices, consumption or production levels, enterprise revenues, intermediate inputs, or production factors. Economists refer to this dimension as the "formal" or "statutory" incidence of subsidies. (The economic incidence of a subsidy - that is, who benefits from it - depends on numerous factors, particularly supply and demand elasticities.) Again, as with transfer mechanisms, multiple stages in the supply chain of a particular product may be subsidized, or taxed, or both. In some countries it is common for upstream petroleum activities to be subsidized, particularly through tax breaks, but for the processed product to be heavily taxed at the point of final sale.

22. Particularly on the production side, subsidies can also differ according to whether they are linked to current or historical production. In several European countries, for example, a large part of government expenditure linked to coal mining goes to pay for liabilities created by past mining, such as to compensate land-owners for subsidence, to cover the medical costs of retired miners, and to clean up acidic water draining from abandoned mines. Even if coal mining were to cease totally in these countries, governments have committed to continue covering these legacy costs for many years.

23. Finally, subsidies differ in their effect on economic behavior at the margin. Some subsidies, such as one-off lump-sum payments, only transfer wealth while others - especially those which change relative prices - also bear directly on decisions on whether to produce or consume more. Some subsidies are open-ended, while others apply limits to the amounts that any individual or firm can receive. Moreover, the effects of a particular subsidy will often depend on how the subsidy interacts with other subsidies and policies. Subsidies that artificially depress prices clearly encourage more consumption than would take place at higher prices. But often to be able to provide an energy product at a low price, domestic producers have to be subsidized to cover their operating losses. Similarly, although the effect of subsidizing one high-cost producer of, say, coal, may have a negligible effect on the world price, the effects of many countries subsidizing their high-cost coal producers may be to depress the world price, thus stimulating consumption elsewhere.

24. To understand the effects of subsidies and taxes on an energy sector and on consumption in a given country requires establishing a complete picture of the market in which it operates and of the various policies - past and present - that have applied to it.

\subsubsection{Frameworks for organizing subsidy information}

25. Identifying all the policies that confer subsidies to a sector and its products is obviously the first step to developing such a picture. It is helpful to classify the individual subsidies according to multiple dimensions. Normally, the unit of interest in subsidy analysis is a sector or, more often, a specific product or service. Organizing the information according to individual fuels, where possible, can help in understanding the impacts of different subsidies on greenhouse gas (GHG) emissions, a prime motivating factor behind the G-20 commitment. Should subsidy phase-out be justified on the grounds of climate change mitigation objectives, then the provisions of the United Nations Framework Convention on Climate Change (UNFCCC) should apply, in particular the principles of equity, and common but differentiated responsibilities and

$5 \quad$ For the purpose of this report, the term "producers" refers to corporate enterprises or individuals engaged in a productive activity, and never to a country that is a producer of energy. 
respective capabilities, as well as the provision that "economic and social development and poverty eradication are the first and overriding priorities of the developing country Parties." The other two main dimensions are transfer mechanism and statutory incidence (Table 2.1). The former is useful for understanding the source of the subsidies, and the latter for understanding how they affect the behavior of energy consumers and producers. Quantifying support therefore involves estimating the values of these various transfers and summing them up (for more details see the Background Paper "Measuring Support to Energy - Version 1.0" prepared by the OECD Secretariat). ${ }^{6}$

26. The producer support estimate (PSE) and the consumer support estimate (CSE) are the most common accounting framework used to organize subsidy information, and to derive subsidy metrics (e.g., OECD, 1987 and 2010b; IEA, 1988; Mullen et al., 2004). This framework has been used extensively to measure support for agricultural commodities, and a similar metric (not including market price support) has been used to estimate support to the fishing industry. Typically, for primary products (agricultural products, fish, forest products, minerals, fossil fuels) the dividing line between production and consumption is drawn at the property boundary of the primary producer - e.g., the wellhead or the mine. Every activity downstream then becomes "consumption". However, for energy it may be useful to either divide the consumption side into several categories, such as transformation, transport and final consumption, or to draw the dividing line further downstream from the wellhead or mine.

Table 2.1 Matrix of transfers, with examples of specific support policies

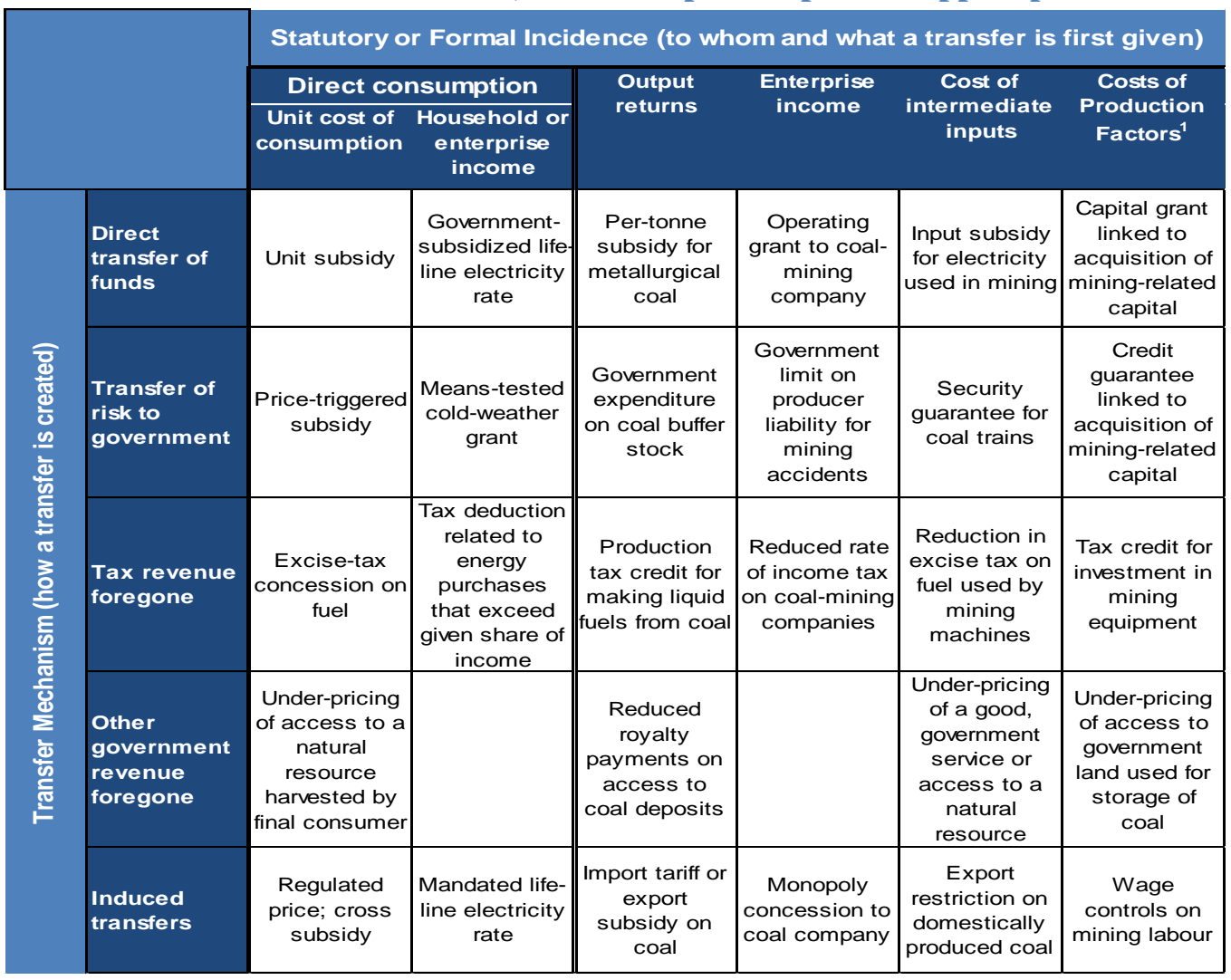

6 There have been a number of criticisms of measuring subsidies as transfers, starting with Peters (1988) and more recently by Oskam and Meester (2006), who note the lack of a clear relation to the economic measures determining support for producers following a policy intervention. Measures such as the PSE and CSE (and therefore elements of those indicators, such as those measured through market price differentials) reflect the policy effort rather than the policy effect, as they are based on an input rather than output measurements. See Tangermann (2006) for a response to these criticisms. 
Source: $O E C D$

Note: 1. Labour, land, capital, knowledge.

27. Within the CSE, the major headings are price-related transfers to (or from) consumers, and budgetary support (including tax expenditures) tied to consumption. Within the PSE, a number of sub-categories of support are applied, usually ranked (roughly) from the most distorting to the least distorting: support based on output, support for the use of intermediate inputs, support for value-adding factors, and support based on revenues or income. When combined with information on the volume and value of subsidized production and consumption, metrics can be constructed from the data contained in the PSE-CSE accounts, such as CSE per litre consumed or PSE per tonne produced, or \% CSE or \% PSE, that can then serve as useful indicators in monitoring reform.

28. When constructing an inventory of subsidies, it is also important to identify factors that limit the eligibility for, or total amount that can be paid out in, subsidies, where applicable. Some energy consumption subsidies are only targeted at people with household incomes below a certain threshold, which helps to limit "wasteful" consumption. Identifying policy variables that are triggered by external factors are also critical in understanding annual variations in subsidies. Some subsidies, for example, are only triggered when fuel prices exceed a certain threshold.

\subsection{Measurement approaches and challenges}

29. Transfers supporting energy consumption and production are most often provided through interventions that raise or lower prices paid by consumers or received by producers. These price effects may arise in particular either through government regulations on prices or volumes (such as consumption mandates), or border interventions, notably import tariffs or export controls or taxes (ADB, 2009). One of the most common approaches used in the literature to estimate such transfers involves comparing actual prices for a given commodity (petroleum fuel, electricity, coal) with a reference price, and multiplying the market price differential, or "price gap", by the affected volume produced or consumed (e.g., Kosmo, 1987; Larsen and Shah, 1992; IEA, 2008; Morgan, 2007, UNEP, 2008, Coady et al., 2010). In countries in which undercollection of bills (particularly of electricity) is significant, or in which illegal theft is rife, a variant of the approach, called the "hidden-cost approach", can be used to estimate the total transfers associated with these phenomena, as well as normal sales at below-cost prices (see Ebinger, 2006). ${ }^{7}$

30. While the method for estimating a market price differential is, in principle, straightforward, numerous conceptual and practical issues need to be considered in order to develop reliable and robust estimates. Conceptually, differences of opinion exist among analysts as to what reference price to use. The price-gap method is tied to the opportunity cost of a pricing policy. In the case of an internationally traded product, the reference is the export or import unit value (adjusted for internal transport costs and quality differences, where applicable), depending on whether the country is a net exporter or net importer of the product concerned. In the case of a product that is not commonly internationally traded, such as electricity, the opportunity-cost reference price is usually estimated on the basis of the long-run cost of production. The price-gap method has limitations which apply particularly in the case of countries with large endowments of energy resources (Box 2.1). In particular, according to OPEC, the appropriate benchmark for these

$7 \quad$ The hidden-cost calculator used by Ebinger (2006) and by Saavalainen and ten Berge (2006) takes into account the excess costs of generating and distributing electricity that are not covered by revenues from electricity rate-payers and hence require a subsidy. The three components of hidden costs are: underpricing, unaccounted for losses, and extra costs due to poor collection efficiency. To calculate the hidden cost, performance data at the country level are required, including end-user electricity tariffs, loss rates, bill collection rates, and energy sent out. 
countries is the cost of production, as also reflected in some of the country definitions proposed in the G-20 context.

31. Estimating market-price differentials, or price-gaps, for some energy products is easier than for others. The data required to estimate a price gap for some petroleum products, such as gasoline and diesel fuels, are usually reported in the trade press, or at least can be easily observed. ${ }^{8}$ Current prices are also a good proxy for the actual prices that would have been paid during a given period, at least for marginal changes in production or consumption. By contrast, coal is mostly sold under long-term contracts (or through vertical transactions within a company that both mines and uses the coal) with set prices, whereas the prices reported in the press usually refer to those associated with the spot trade, or sales under short-term contracts. For kerosene, LPG, natural gas and electricity, end-use prices to residential consumers may be reported, but those to large industrial users may be obscure. Estimating the cost of production is also an exercise in approximation, and can be very data-intensive, especially in large countries with regional variations in sources of energy used to generate electricity.

\section{Box 2.1 Challenges and Limitations of the Price-Gap Methodology}

This report relies on estimations of market price differentials, or price-gaps, for various sources of energy. It should be recognized that this method relies on a number of assumptions:

1) Identifying the appropriate cost. Many different measures of cost exist, including average cost, marginal cost and opportunity cost. Exporting countries with large energy endowments prefer to use cost of production as a benchmark. What is more, energy costs are highly variable as not all commodities are widely traded.

2) Identifying the appropriate price. Although the price quoted in global markets is typically used as a measure of opportunity cost, international prices may be distorted by a variety of factors and can experience a high degree of volatility.

3) Price-gap estimates do not capture producer subsidies. Therefore, subsidy estimates based only on price-gap measurements tend to underestimate the level of subsidies in developed countries.

Other caveats also necessitate exercising caution when interpreting or explaining market transfers (to consumers) and market price support (to producers) in any given year. In international markets, U.S. dollar prices, especially of crude oil and petroleum products, have been highly volatile in recent decades, as has the value of the U.S. dollar against other currencies. These two elements combine to make estimates of market transfers from one year to the next also highly variable.

32. Direct, budgetary transfers are the most straight-forward types of subsidies to measure, although this depends on how well reported they are in government budget documents. Government accounts differ in their level of transparency and accuracy in reporting actual expenditure, however, and this can add substantially to the difficulty of the data-collection task. Even in countries with detailed and transparent budgets, the subsidies of interest are reported in an aggregated way, requiring allocation to specific products, such as the various petroleum products produced by a subsidized refinery.

33. Tax expenditures can in theory be approached in the same way as budgetary transfers. Tax-expenditure estimation has been traditionally undertaken against a benchmark tax system particular to the country undertaking the estimates, not a benchmark that is common to all countries. Caution is therefore required when comparing tax-expenditure estimates across countries.

$8 \quad$ However, the markets for many other refined petroleum products are less transparent than for crude oil, so identifying the relevant market price can be significantly more difficult. 
34. Tax exemptions directed at particular groups (e.g., farmers) weaken the incentives to increase energy-efficiency for those groups and affect demand patterns within a country. Moreover, tax exemptions that are granted to one fuel and not to a close substitute can lead to the illegal diversion of the non-taxed fuel (e.g., kerosene) to a taxed product (e.g., petroleum diesel)..

35. Governments also forego revenue by offering the use of non-depletable (e.g., land) or depletable assets (e.g., fossil-fuel resources) under their control. This can reduce production or consumption costs and thereby encourage more consumption than otherwise. The most direct case is providing access to domestic resources of fossil fuels that a private company (or individuals) then exploits for their own use or for sale. But governments also provide access to intermediate inputs, like water or electricity, at below market prices, and access to government buildings or land. Estimating the value of such transfers involves comparing the actual price charged for use of the assets with the price that would be charged in an open market (e.g., through competitive bidding).

36. Estimating the cost to government, or the value to beneficiaries, of government assumption of risk is potentially one of the most complex and controversial areas of subsidy estimation. Yet its importance to investment in energy-production facilities, and in energy-using capital, is often crucial. Governments assume some of the risk of energy producers through all manner of measures, but most commonly by guaranteeing loans, by becoming an equity participant in an energy company, by acting as the insurer of last resort in the case of an accident affecting workers or the general public, and by providing extra military or police protection to key energy facilities or energy-transport corridors. In all of these cases, the actual cost to government of a riskreducing measure depend on the probability that it will incur costs (from, respectively, a loan default, an accident, or an attack), which may be anywhere from low to highly probable in any given year. What matters in terms of effects on producer or consumer behaviour, by contrast, is the value of such assurance to the beneficiaries.

37. In sum, although energy subsidies are widespread, they vary considerably in type and importance across different fuels, countries and over time. Accordingly, estimating their size can be difficult. Because of differences in definitions, and the varying transparency of fiscal systems, it is even more difficult to reconcile regional or individual country studies measuring the magnitude and impact of energy subsidies.

\subsection{Review of energy-subsidy estimates}

\subsubsection{Subsidies to fossil fuels}

\section{Subsidies related to the consumption of fossil fuels}

38. Most of the data on energy consumption subsidies that have been published for multiple countries in recent years relate to oil, natural gas and coal (IEA, 2010 and 2008) or petroleum products only (Coady et al., 2010), and have relied on the measurement of price-gaps. Based on application of the price gap approach to its dataset, the IEA estimates that fossil fuel subsidies to consumers amounted to US\$ 557 billion in 2008. ${ }^{9}$ This amount comprises subsidies to fossil fuels used in final consumption and subsidies to fossil-fuel inputs to electric power generation. The total value of subsidy increased substantially from 2007, when the IEA estimates it amounted to US\$ 342 billion. Fluctuations in world prices, domestic pricing policy changes, and shifts in demand can all be responsible for year-to-year differences in subsidy estimates; however,

9 It is estimated that the 37 countries surveyed in the IEA dataset, including both OECD and nonOECD countries collectively represent over $95 \%$ of global subsidized fossil-fuel consumption. Revised estimates of consumer subsidies for 2009 will be available in time for the Korean G20 Summit in November 2010, once data for the full year becomes available for all countries in the IEA energy subsidy database. 
the main reason for the increase between these years was the unprecedented rise in prices during the first half of 2008. Since 2008, a number of countries - including China, Russia, Indonesia and Malaysia - have made notable reforms to bring their domestic energy prices into line with world prices. These efforts are expected to have contributed to a reduction in their spending on energy subsidies in 2009.

Moreover, the analysis carried out by the IEA reveals the high cost of subsidies (Box 2.2). Consumption of oil products and natural gas were commonly subsidized, totaling US\$ 312 billion and US\$ 204 billion, respectively, in 2008. The IEA reports US\$ 40 billion in subsidies for coal, mostly provided indirectly through subsidized electricity prices (Fig. 2.1).

39. However, it is worth noting that the price-gap methodology has shortcomings. OPEC is of the opinion that the benchmark price to be used in the case of energy resource well-endowed countries should be the cost of production. Consequently, OPEC could not associate itself with the above estimation of fossil-fuel-related consumption subsidies. ${ }^{\mathbf{1 0}}$

\section{Box 2.2 The Price-Gap Methodology}

The IEA analysis of consumption subsidies used the price-gap approach. For a given product, the price gap is the difference between a reference price and the actual retail (end-use) price. For net importing countries, reference prices were based on the import parity price: the price of a product at the nearest international hub adjusted for quality differences and plus the cost of freight and insurance to the importing country, plus the cost of internal distribution and marketing and any value-added tax (VAT). For net exporting countries, reference prices were based on the export parity price: the price of a product at the nearest international hub adjusted for quality difference, minus the cost of freight and insurance back to the exporting country, and plus the cost of internal distribution and marketing and any valueadded tax. To evaluate the subsidies for fossil-fuel inputs into the power generation sector, electricity reference prices were based on annual average-cost pricing for each country (weighted by the levels of output of each generating option). These were determined using reference prices for fossil fuels, annual average fuel efficiencies, and transmission and distribution and other costs. To avoid over-estimating subsidy levels in the power-generation sector, electricity reference prices were capped at the levelized cost of a combined-cycle gas turbine (CCGT) plant.

Source: $\operatorname{IEA}(2010)$

Fig.2.1 Consumption-related subsidies, by fossil fuel, in 2008

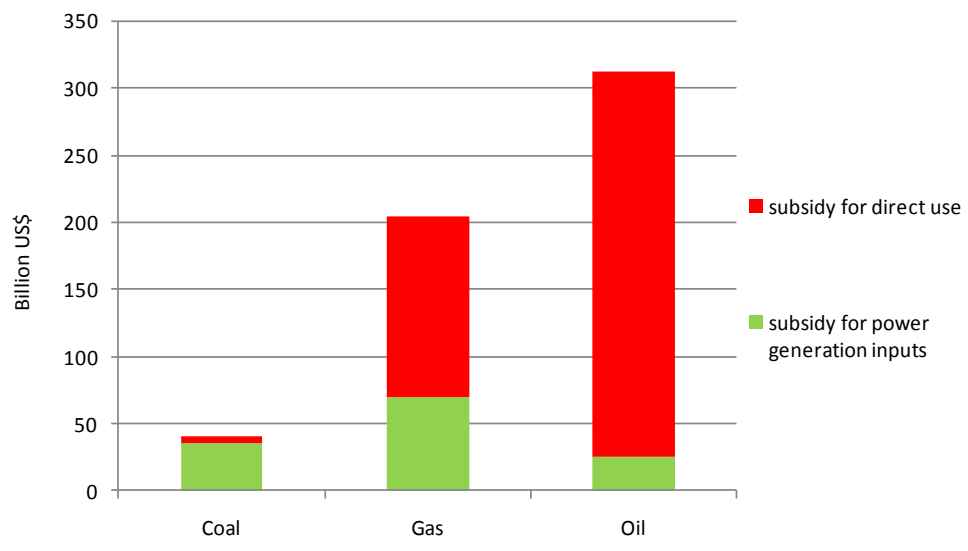

Source: IEA (2010)

10 The IEA has offered to undertake a sensitivity analysis of its price gap consumer subsidy estimates, that would use the cost of production as the reference price for energy resource well-endowed countries, if the necessary data is made available. 
40. Using the price-gap methodology for an analysis focusing exclusively on petroleum fuels, staff of the International Monetary Fund estimated that the global cost of subsidizing gasoline, diesel and kerosene would have exceeded US\$ 500 billion per year in 2008 (when assessed over the entire year at the international spot prices for each product at their mid-2008 peak). From end-2008 to mid-2009, global subsidies are projected to increase from the lowest annual rate of US $\$ 50$ billion to almost US $\$ 140$ billion, reflecting the high volatility of oil prices (Coady et al., 2010).

41. In many developing countries, price-gap comparisons understate the total size of the subsidies involved, particularly because of theft and poor rates of bill collection, in addition to underpricing. In 2006, the World Bank estimated the hidden costs of providing electricity in Eastern European and Central Asian (ECA) region, where policies often ensure universal access to electric power regardless of cost. Electricity tariffs set at below cost-recovery rates in the ECA region were found to account for $67 \%$ of aggregate hidden costs, followed by unaccounted losses at $22 \%$, and poor collections at $11 \%$. High hidden costs were estimated to represent on average $4 \%$ of GDP, but for some countries, such as Serbia and Tajikistan, they were well above $10 \%$ of GDP (Fig. 2.3). Hidden costs have fallen in most countries of the ECA region since then as a result of a comprehensive set of reforms, including regulatory reforms, private-sector participation and increased competition (Vagliasindi, 2004; Vagliasindi and Izaguirre, 2007).

42. A similar exercise undertaken for 21 countries in Sub-Saharan Africa confirms that underpricing accounts for a majority (about 50\%) of the aggregate hidden costs, with the rest divided roughly evenly between distribution losses and revenue under-collection. In the worst cases-Democratic Republic of Congo, Malawi, and Zambia — under-pricing can result in utilities capturing less than half the revenues they need and create an economic burden in excess of $2 \%$ of GDP (AICD and Briceno et al., 2009). These figures probably understate the under-pricing due to the difficulty of measuring subsidies to large industrial and mining customers that are usually contained in bilateral contracts and not reflected in the general electricity tariff structure. Key examples include the aluminum smelting sector and the mining sector in Zambia, where large strategic customers have purchased electric power at heavily discounted rates (World Bank, 2008; Vagliasindi and Nellis, 2010).

\section{Fig. 2.3 Power sector hidden costs for Eastern Europe and Central Asia and Africa}

a) ECA (2000-2003)

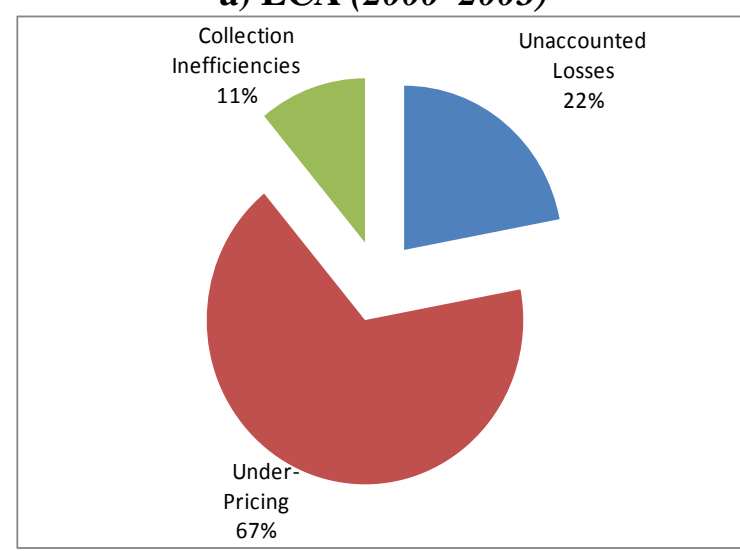

Source: Ebinger (2006) for ECA and AICD (2009) for AFR. b) AFR (2001-2006)

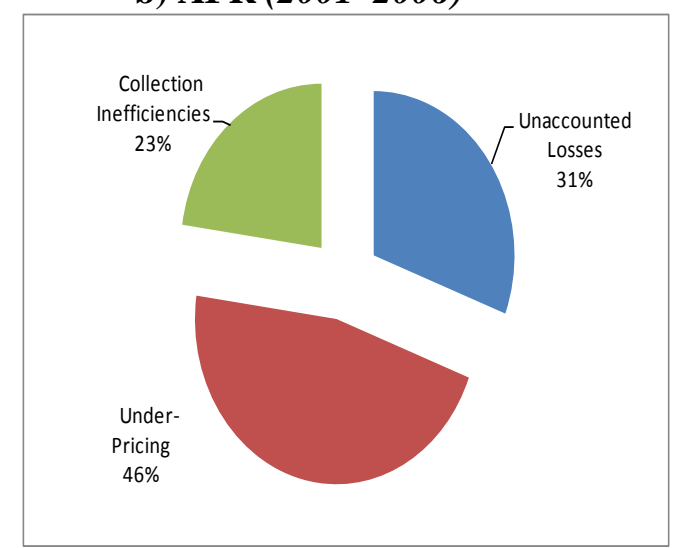

43. Among the forms of subsidies to consumption that are not measured by price-gap or hidden-cost analyses are direct subsidies for consumers that do not affect the market price of energy. Some of the ways that such subsidies are provided are through the distribution of vouchers that entitle households to a certain amount of fuel at a discounted price, and programs that transfer 
money to enable low-income households to pay their heating bills. The United States' Low-Income Home Energy Assistance Program (LIHEAP), for example, provides grants (up to US\$ 5.1 billion in FY2010) to vulnerable households to help them pay their heating bills. Such targeted assistance programs - which arguably do not encourage "wasteful" consumption (see Chapter 4) - exist in a number of other countries, but have not yet been quantified. Some countries' income-tax codes encourage employers to offer their executives company cars and free fuel in lieu of higher salaries. Other direct payments related to energy consumption have included grants to farmers to help defray unexpectedly high fuel costs.

44. A large, but so far not completely quantified, share of support for energy production and consumption in advanced economies is provided through tax expenditures - tax exemptions, preferential rates and other design features that differ from the standard tax regime. Where data do exist, they reveal that the tax expenditures range from minor relief to selected consumers or industries to broad relief to all taxpayers.

45. The special rules and tax advantages that give rise to these indirect subsidies can be relatively subtle and complex, making them less apparent than direct subsidies to fossil-fuel prices. The most important tax expenditures on the consumption side include reduced VAT rates, which lower the cost of fossil fuels for final consumers, and full or partial exemptions from excise duties for fossil-fuel use in sectors such as agriculture, fisheries and the public sector. Some examples are given below in Box 2.3, but need to be interpreted with caution, as methods of estimating tax expenditures differ widely among reporting countries. For some examples, the amount of revenue foregone may not be huge, but with many special rules dispersed across the tax system, the total indirect fossil-fuel subsidy can be substantial. 


\section{Box 2.3 Examples of tax expenditures on intermediate and final consumption of fossil fuels in $O E C D$ countries}

Reduced VAT rates and VAT exemptions for fossil fuels. Reduced value-added tax rates are typically targeted at heating fuels. Italy, for example, applies a $10 \%$ VAT rate to the first 480 cubic meters of natural gas supplied annually to each household, compared with a standard VAT rate of $20 \%$. Korea has a VAT exemption for domestically produced anthracite coal typically used by the poor for heating and cooking In the United Kingdom, all fuel and power for households' domestic use, i.e. heating and electricity, has a reduced VAT rate of $5 \%$, clearly below the standard rate of $17.5 \%$. The tax revenue thereby foregone is equivalent to $0.25 \%$ of GDP, the bulk of it relating to fossil fuels either directly or indirectly via electricity generated from coal, etc.

Tax exemptions for "clean" gas fuels. Fuels such as compressed natural gas and liquefied petroleum gas are less environmentally damaging than other fossil fuels for transportation, but they still contribute to $\mathrm{CO}_{2}$ emissions. Australia currently completely exempts these gaseous fuels from the excise duty applied to other fuels and estimates that this tax expenditure amounts to $0.06 \%$ of GDP.

Low tax rates for diesel and exemptions for agriculture and fisheries. Many countries set excise duties on transportation fuels at relatively high rates in order to reflect wider externalities such as air pollution and road accidents, and to finance road construction or raise revenue more generally. Against that background, it is sometimes argued that diesel used off-road by agriculture and fisheries should be taxed at a lower rate. However, the complete exemption seen in many countries implies tax rebates that often exceed what could be considered a road-user payment, and diesel combustion contributes equally to $\mathrm{CO}_{2}$ emissions irrespective of where it takes place. As one example, Japan exempts agriculture, forestry, fisheries and mining from excise duties on diesel. Turkey estimates that its exemption for diesel used by fisheries and shipping represents a tax expenditure of $0.03 \%$ of GDP. For OECD countries as a whole, these tax concessions are worth some US\$ 8 billion a year to the agricultural sector, and at least US\$ 1.1 billion a year to the fisheries sector, according to preliminary OECD estimates. Moreover, many countries have lower excise-duty rates for diesel for road use than for petrol.

Automatic tax cuts and subsidies when fuel prices rise. In Mexico's unusual form of excise tax for petrol and diesel, rates change each month. When the international oil price rises above US\$ $40-45$ per barrel, the tax rate turns into a subsidy. With low oil prices in 2002, this mechanism resulted in net revenues of $1.2 \%$ of GDP, but with high oil prices in 2008 it resulted in net subsidies of $1.8 \%$ of GDP.

Tax exemptions for fuel used by the public sector. Where taxes are only intended to raise revenue, it is natural to exempt publicly financed activities. But taxes meant to price externalities may be equally relevant for guiding input substitution in public as in private-sector activities. Public subsidies to education, health care, and collective transport should rather be general than channelled via underpriced tax-free fossil fuels. France, for example, had excise duty exemptions for natural gas used for heating by public agencies and fuel used by the military, but these exemptions have since been ended, starting in fiscal year 2009-10.

Source: National authorities, research literature and OECD data on environmentally-related taxes.

Note: The factual information in this box has been reviewed by the countries concerned, but the box as a whole has not been discussed by OECD Committees and Working Parties.

\section{Subsidies related to the production of fossil fuels}

46. No systematic effort has been undertaken within the last decade to estimate subsidies to fossil-fuel production over a wide range of countries, although there have been various national-level efforts to identify and quantify subsidies, both for particular fossil fuels and for energy as a whole. These studies have been undertaken by governments agencies in some cases (e.g., U.S. EIA, 2008; Berg et al., 2010), but just as often by non-governmental researchers (e.g., Koplow, 2010; Koplow, 2004; Storchmann, 2005).

47. The most market-distorting forms of support to production are those that support producer prices. Government-brokered arrangements between domestic coal producers and 
electric utilities that forced the utilities to buy domestic coal at a price much higher than the world price were commonplace in Europe until the mid-1990s (Steenblik and Coroyannakis, 1995). Many, although not all, OECD countries have removed such subsidies or are in the process of phasing them out. Whether such arrangements exist elsewhere has yet to be determined.

\section{Box 2.4 Examples of tax expenditures relating to the production of fossil fuels in OECD countries}

Favourable tax deduction for depletion of oil and gas fields and coal deposits. Normally businesses can only deduct actual expenses and depreciation from the corporate income tax base. But in the United States, a special rule allows fossil-fuel and mineral producers to deduct a fixed percentage of gross revenue instead of the value of the actual depletion. This is a highly favourable tax provision and can even continue after the expenses to acquire and develop a field or mine have been recovered. For fossil-fuel producers alone, this tax expenditure is estimated at $0.002-0.004 \%$ of GDP. The US administration's 2011 budget proposal would end this and a number of other fossil-fuel-related tax expenditures.

Accelerated tax depreciation allowances for capital equipment. The extraction and processing of fossil fuels is highly capital intensive. Special rules that allow businesses to deduct depreciation faster than the actual speed at which equipment becomes economically obsolete can therefore in some cases imply large indirect subsidies. The issue is complicated by the special tax and royalty regimes targeted at natural-resource rents. For oil sands in Canada, the annual costs of this tax advantage amounts to $0.02 \%$ of GDP, estimated in cash-flow terms. The measure will be phased out by 2015 .

Tax exemption for fossil-fuel producers' own energy use. Most OECD countries have excisetax exemptions for fossil fuels used in the production process in coal mining, oil extraction, refineries, etc. The magnitude of this tax expenditure will depend on the volume of energy production in each country. Even in Germany, which is not a large energy producer, it is estimated to be worth $0.01 \%$ of GDP.

Source: National authorities, research literature and OECD data on environmentally-related taxes.

Note: The factual information in this box has been reviewed by the countries concerned, but the box as a whole has not been discussed by OECD Committees and Working Parties.

48. Most G-20 countries apply low or zero import tariffs on imported crude petroleum. India, Russia, Saudi Arabia, and South Korea are notable exceptions, with the first three countries applying most-favored nation (MFN) ${ }^{11}$ import tariffs of 5\%, and South Korea applying a tariff of $3 \%$, on crude. On average across the G-20 economies, import tariffs are higher on refined petroleum products than on crude oil, with several economies applying import tariffs as high as $9 \%$ on certain petroleum products, but a zero tariff on crude oil. Only a few countries apply import tariffs above 3\% on coal or lignite: Indonesia levies a 5\% import tariff on all coal, and India levies an import tariff of $10 \%$ on some forms of coal, and on lignite. Russia applies a flat $5 \%$ import tariff on all fossil fuels except natural gas, Saudi Arabia applies a flat 5\% import tariff on all fossil fuels including natural gas.

49. Regarding tax expenditures related to fossil-fuel production, advantageous deductions in the corporate income tax base for field depletion or accelerated capital depreciation are the most important (Box 2.4). These can encourage higher levels of production than would otherwise be demanded by the market. Some of these types of tax expenditures have

11 Import tariffs may exaggerate the degree of effective protection. First, there may be "water" in the tariff, meaning that the actual gap between the domestic price and the international price is not as large as the tariff. But in the case of traded fossil fuels (coal and petroleum), the import tariff is probably a good (and easily measured) proxy for estimating market price support. Second, not all trade occurs under MFN tariffs; a growing volume of trade occurs between partners in free-trade agreements (e.g., between Mexico and the United States). 
been scaled back, but increased transparency and refined measurement of fossil-fuel tax expenditures would help advance the reform process.

50. Another area of government involvement in fossil-fuel production is investment in research and development (R\&D). In 2008, the IEA reports that total government expenditure on R\&D related to fossil fuels amounted to almost US $\$ 1.7$ billion. Included under this category of expenditure is R\&D related to enhanced oil and gas production; un-conventional oil and gas production; refining, transport and storage of oil and gas; oil, gas and coal combustion; and oil, coal and gas conversion. G-20 member economies account for the bulk of this expenditure. Also included in this category is expenditure on the capture and storage of carbon emissions from combustion, which has increased steadily in recent years (Table 2.3). Carbon, capture and storage (CCS) facilitates consumption of combustible fuels, including fossil fuels, but is intended to reduce release to the atmosphere of $\mathrm{CO}_{2}$ emissions associated with such combustion. Should subsidies' phase-out be justified on the ground of climate change mitigation, the provisions, including the principles of equity and common but differentiated responsibilities of the UNFCCC should apply.

Table 2.3 Government expenditure on R\&D by total IEA countries and selected G-20 countries, 2005-2008 (Millions of U.S. dollars at 2008 prices and exchange rates)

\begin{tabular}{|c|c|c|c|c|}
\hline Total IEA countries & 2005 & 2006 & 2007 & 2008 \\
\hline$R \& D$ related to fossil fuels & 1,378 & 1,484 & 1,507 & 1,658 \\
\hline Of which selected G-20 countries: & 1,151 & 1,255 & 1,256 & 1,190 \\
\hline Of which is for carbon capture and storage (CCS): & 101 & 157 & 186 & 218 \\
\hline $\begin{array}{l}\text { R\&D related to energy for civilian purposes from nuclear } \\
\text { fission and fusion }\end{array}$ & 4,893 & 4,903 & 4,957 & 5,476 \\
\hline Of which selected G- 20 countries: & 4,643 & 4,640 & 4,720 & 4,496 \\
\hline $\begin{array}{l}\text { R\&D related to renewable energy sources, hydrogen and } \\
\text { fuel cells }\end{array}$ & 1,255 & 1,367 & 1,667 & 1,755 \\
\hline Of which selected G-20 countries: & 976 & 1,027 & 1,237 & 1,218 \\
\hline
\end{tabular}

Source: IEA 2009. G-20 countries reported in this table include Canada, France, Germany, Italy, Japan, Korea, Turkey, United Kingdom and United States

\subsubsection{Subsidies to non-fossill-fuel energy sources}

51. Fossil fuels are by no means the only forms of energy that governments subsidize. Countries with large fission nuclear power programs incurred large costs in the form of expenditure on R\&D and loans, loan guarantees and grants for the construction of new power plants, especially from the late 1950s through the early 1980s; subsidies for R\&D into fusion power began in the 1970s. Government expenditure on nuclear-power-related R\&D (both fission and fusion) has been increasing steadily in recent years (Table 2.3), to an estimated US $\$ 5.5$ billion in 2008 among the advanced economies of the G-20, as have government loan guarantees.

52. Government support for technologies to harvest energy from renewable sources of energy has increased dramatically in line with interest in finding low-carbon alternatives to fossil fuels. On the consumption side, tax reductions, credits and exemptions, and regulations requiring a minimum share or volume of biofuels in transport fuels, are used by a large number of countries to support the use of liquid biofuels. In 2006, these interventions were worth at least US\$ 10 billion in OECD countries alone (Steenblik, 2007); with expanded use, the value of OECD countries' subsidies will probably exceed US\$ 15 billion in 2010. Similar support measures are used in Brazil (Kojima et al., 2006), China (Global Subsidies Initiative, 2008) and Indonesia (Dillon et al., 2008), though the volumes supported are still small. Support per unit of energy produced can be very high, however. For example, in several countries cellulosic ethanol is subsidized at a rate of 40 U.S. cents per litre or more. It has been estimated that, if existing 
programmes are continued and production targets are met, the cumulative cost of biofuel subsidies in the United States could exceed US\$ 1 trillion over the next two decades (Koplow, 2009b).

53. Subsidies for the production of renewable energy take on many forms. In the case of biofuels, which are mainly used for road transport, and biomass, which is used in advanced countries as a fuel for electric power plants, production facilities are often supported with grants, government loans at preferential rates, and loan guarantees. Producers can often benefit from special tax facilities. In the case of technologies that produce electricity from renewable energy (hydro-electric power, solar energy, wind, waves and tides, biomass), production costs are often subsidized in advanced economies, and some emerging economies, by regulations that require that a certain proportion of a service area's electricity supply be provided by renewable energy, or by special "feed-in" tariffs - prices paid to generators of electricity that are higher than those paid to plants that run on fossil fuels. Several emerging countries have also introduced feed-in tariffs renewable portfolio standards, or tradable certificates to support the expansion of renewableenergy-based electricity, including Argentina, Brazil, Chile, China, India, the Philippines and Turkey. The construction of these plants is also often supported through capital grants and government loan guarantees. ${ }^{12}$

54. As with nuclear energy, comprehensive estimates of subsidies to renewable energy are not available, but estimates of government $R \& D$ expenditures are available for advanced countries. Table 2.3 shows that the amount of government expenditure by IEA countries on R\&D related to renewable energy, hydrogen and fuel cells has been steadily increasing in recent years, and was an estimated US\$ 1.8 billion in 2008. However, these figures may under-state actual expenditures to the extent that they exclude, for example, $R \& D$ expenditures relating to energy production financed by agricultural ministries.

55. Subsidies to non-fossil-fuel energy are considerable and have been increasing over time. A rough estimate by the GSI indicates around US\$ 100 billion per year are spent to subsidize alternatives to fossil fuels. Subsidies are concentrated in OECD countries, which are responsible for the generation of over $80 \%$ of current world nuclear and renewable electricity and two-thirds of biofuel production (Table 2.4). Based on GSI estimates provided by OPEC, renewable energy sources and biofuels are subsidized at a much higher rate than fossil fuels (the per unit basis subsidies to renewables and biofuels are equal to US cents 5.0 per kWh, compared with US cents 1.7 per $\mathrm{kWh}$ for nuclear power, and US cents 0.8 per $\mathrm{kWh}$ for fossil fuels). Revenues raised through taxes levied by OECD countries on energy, mainly fossil transport fuels, exceeded US\$ 400 billion over the OECD region in each of the years between 2003 and 2008; these taxes significantly affect end-use relative prices for fuels. ${ }^{13}$ Based on IEA energy price and tax data, OPEC estimates that US $\$ 800$ billion has been raised annually through petroleum product taxation, including Goods and Services Tax and Value Added Tax, in the OECD region, between 2004 and 2009.

12 Many economists have argued that policies that internalize the cost of pollution, such as through a charge on emissions, though more difficult to implement would be more cost-effective.

13 Source: OECD/EEA database on instruments used for environmental policy (www.oecd.org/env/policies/database) 
Table 2.4 Preliminary Estimates of Subsidies, 2007

\begin{tabular}{|c|c|c|c|c|}
\hline Energy type & $\begin{array}{c}\text { Subsidy } \\
\text { estimate (US\$ } \\
\text { billion/year) }\end{array}$ & $\begin{array}{l}\text { Energy } \\
\text { produced } \\
(2007)\end{array}$ & $\begin{array}{l}\text { OECD Share } \\
\text { of production } \\
(2007)\end{array}$ & $\begin{array}{c}\text { Subsidies per } \\
\text { energy unit } \\
\text { USc\$/KWh }\end{array}$ \\
\hline Nuclear energy & 45 & $\begin{array}{l}\text { 2,719 TWh } \\
\text { electricity }\end{array}$ & $84 \%$ & 1.7 \\
\hline $\begin{array}{l}\text { Renewable energy (excluding Hydro- } \\
\text { electricity) }\end{array}$ & 27 & $\begin{array}{l}534 \mathrm{TWh} \\
\text { electricity }\end{array}$ & $82 \%$ & 5.0 \\
\hline Biofuels & 20 & 34 Mtoe & $68 \%$ & 5.1 \\
\hline Fossil Fuels & 400 & 4172 Mtoe & & 0.8 \\
\hline
\end{tabular}

Source: preliminary estimates based on GSI (2010), available at

http://www.globalsubsidies.org/files/assets/relative_energy_subsidies.pdf.

\section{Reforming and phasing-out inefficient energy subsidies}

\subsection{Impact of inefficient energy subsidies and subsidy reform on sustainable development}

\subsubsection{Economic and sectoral impacts}

56. Phasing out inefficient energy subsidies could have direct positive effects on the economy, particularly in the longer-term, if it reduces economic distortions. Given that governments have limited budgets, continued inefficient energy subsidies could crowd out public support for promising, cleaner energy technologies, and for other public priorities.

57. Energy subsidies lead to a worsened fiscal balance due to increased government expenditures or net current transfers and can affect the balance of payments as changes in prices of imports or exports subject to the subsidy affect trade flows via price and real exchangerates. The dislocations within an industrial sector will be much smaller with multilateral reform since the ability to pass through cost increases will be higher. More directly, energy-consumption subsidies lead to increased domestic demand for imported or potentially exported energy products, thus worsening the trade balance.

58. The impact on industrial output of phasing out energy subsidies depends on at least three parameters: (1) the importance of energy inputs in production as represented by their cost shares; (2) the ease with which energy can be substituted by other inputs, whether to cheaper fuels or through reduced energy use; and (3) the ability of producers to pass on the increase in energy costs to consumers, as measured by the elasticity of demand for output, which in turn, depends on whether reforms are done unilaterally or multi-laterally. ${ }^{14}$ These parameters vary across production activities and countries. With the exception of energy-intensive activities such as metal and nonmetallic products and pulp and paper, energy cost shares in most industries are relatively low, between $0.5 \%$ and 3\% (ESMAP, 2003, World Bank, 2009). Shares for individual fuels are even lower. But, as noted earlier in the report, inefficient subsidies often encourage more energyintensive industries, and so their phase out would more adversely impact the industries of heavily subsidizing countries.

59. Similarly, the impact on households depends on the elasticity of demand, the expenditure share and the magnitude of the price change and the existing fiscal wedges. Finally, the higher initial tax or subsidy rates are, the more it dampens production-price changes. A

14 The dislocations within an industrial sector will be much smaller with multilateral reform since the ability to pass through cost increases will be greater. 
well-know example is the weak responsiveness of demand for transport fuel in European countries to large change in crude oil world prices, attributable to the fact that domestic taxes on these fuels amount for around $60 \%$ (in the case of premium unleaded petrol in 2007) of the consumer price. There can also be other significant indirect effects on income due to the economic-adjustment process.

60. As inefficient energy subsidies are phased out, the final effect on firms and households depends on whether income or the price effect dominates. Where estimates are available, the price-elasticity of demand for kerosene is close to -1.0 - i.e., a one-percent increase in price leads to close to a one-percent fall in consumption. The price elasticity of demand for electricity is relatively low and lies between -0.08 and -0.32 (ESMAP, 2003, IEG, 2009). IEA analysis indicates an even lower elasticity of demand for electricity, ranging from -0.01 to -0.14 depending on the region. There is an inverse relationship between income levels and energybudget shares, with high-income households typically spending a smaller share of their disposable income on energy than low-income households. Rural households spend a smaller share of their budgets on commercial energy than do urban households. With few notable exceptions, the cost of producing products made from domestically extracted fossil-fuels would increase. As the costs of other goods that use fossil fuels as an input rose as well, household demand for fossil fuels would decline. Detailed analysis of the dynamic relationships involved requires the use of a macroeconomic model, particularly to distinguish between short- and long-run effects.

61. The effect of subsidy removal on world prices for energy depends on several factors. The removal of most consumer subsidies would lead to higher domestic energy prices, hence to reduced demand for the previously subsidized fuel. Whether reduced world energy demand and in particular oil demand would translate into lower world oil prices would depend on the several factors that characterize the behavior of oil suppliers to oil-price changes (Ivanic and Martin, 2008).

62. In several countries with large endowments of fossil fuels, governments have promoted development through policies that encourage adding value to local resource production. This typically involves supplying energy to energy-intensive industries (e.g., petrochemicals, aluminum) at a price lower than the world price, to support regional or national employment and income. Even though it is a sovereign decision, using subsidies to diversify economic activity beyond supplying mainly raw materials - i.e., to create value-adding activities based on those materials - may help in the transition to a more sustainable path of growth, but at a cost of reduced raw-material supplies in the future.

\subsubsection{Social and equity impacts}

63. Studies show that the poor are often willing to pay for better-quality energy but alternatives are frequently either unavailable or entail high access cost. The poor often have difficulty in gaining access to high-quality energy services and businesses may have limited incentives to serve them (e.g., due to low population densities, remote locations and low consumption rates relative to richer sections of society). Energy subsidies can play a useful redistributive role in such situations (Annex 4 prepared by the World Bank).

64. Universal energy-price subsidies tend to be regressive as benefits are conditional upon the purchase of subsidized goods, and increase with expenditure. Studies reviewed by the Independent Evaluation Group (IEG) of the World Bank (IEG, 2009) found that the bottom $40 \%$ of the population ranked by income distribution receives $15-20 \%$ of the fuel subsidies. The greater the leakage to the non-poor, the more regressive the subsidy, and the higher the cost of delivering a given benefit level to the most needy. In addition to direct household consumption, fuels are consumed indirectly through consumption of other goods and services that use them as inputs. An IMF study (Coady et al., 2006) of five countries found that even when direct and indirect benefits are considered, the bottom $40 \%$ of the population typically receive only $15-25 \%$ 
of the value of the subsidies. Even if inefficient, energy subsidies may still play an important role in addressing poverty so this clearly needs to be considered when contemplating any phase-out program.

65. Income groups differ greatly in their energy-consumption patterns, and the distributional impact of subsidies is not the same for all types of fuels and electricity. Lowerincome groups spend a higher proportion of their energy budget on cooking fuels and less on electricity and private transportation. Where subsidies result in switching from traditional fuels and improved access to electricity, such subsidies can bring considerable benefits to the poor. These include less indoor pollution, and less time spent collecting fuel wood, so more time for productive activities. In most cases there are significant differences between the consumption patterns of the rural and urban poor. Subsidies for diesel and gasoline are particularly regressive, as these fuels are used primarily for private transport. Subsidies for kerosene and LPG are potentially less regressive or even neutral, as these fuels are used by the poor for cooking, and for lighting in rural areas. However, because kerosene and diesel are close substitutes in transport uses, maintaining wide price differences between them generally results in adulteration of the latter and substantial leakages of benefits (World Bank, 2008).

66. Examples exist of the social and environmental benefits that some subsidies can bring (UNEP, 2004). A program in Senegal resulted in a shift away from charcoal consumption, with nearly $85 \%$ of households in the capital, Dakar, and $66 \%$ of households in other urban areas now owning LPG stoves. Subsidies to heat, electricity and gas in Russia have lead to inefficient usage but have also aided poor households by maintaining affordable energy supplies in cold regions. Subsidies to improve the thermal insulation of buildings could, in many locations, reduce expenditures on fossil-fuel subsidies.

67. The proportional adverse impact of inefficient energy subsidy removal can be greatest for the poor, even though the rich receive most of the total value of the subsidy. Although subsidies are not an efficient mechanism for delivering resources to the poor, they do act to reduce poverty, albeit at a high cost. In Yemen, data for 2005/6 indicate that petroleum subsidies reduced the incidence of poverty by 8 percentage points, while in Morocco this effect was estimated at about 5 percentage points. The poor will also be affected by fossil-fuel subsidy reform due to indirect effects on transportation and food-production costs (World Bank, 2006). Coady et al. (2006) also found that the removal of fuel subsidies in the five countries surveyed would be regressive (i.e., affect disproportionally the welfare of the poor) or, at best, neutral. Any reforms to phase out inefficient energy subsidies must therefore include measures to mitigate likely negative impacts upon those with the lowest incomes. Reforms to shift subsidies to follow the person rather than the commodity can be helpful in this regard.

\subsubsection{Environmental impact}

68. The environmental effects of energy subsidies depend on the nature of the subsidy and the energy source they support. Phase out of fossil fuel subsidies may lead to reduced demand for fossil fuels, either through improvements in energy efficiency and more efficient fuel use, or through substitution with other fuels or other inputs. To the extent that subsidy phase-out leads to fuel switching (as opposed to simply increased efficiency) the net impact on emissions of greenhouse gases depends on whether the energy source affected is more or less carbon-intensive than the alternative.

69. Reduced demand growth for fossil fuels will also lead to lower emissions of sulphur dioxide $\left(\mathbf{S O}_{2}\right)$, nitrogen oxides $\left(\mathbf{N O}_{\mathbf{x}}\right)$ and particulate matter, which are all harmful to human health and cause environmental problems, such as acid rain, reduced visibility and ground-level ozone formation. 
70. Efforts to bring poorer countries further up the "energy" ladder, towards cleaner and more-efficient fuels, should have positive environmental and developmental impacts. The ordering of fuels on the energy ladder is determined by their efficiency and cleanliness, with the cooking-stove efficiency of firewood at $15 \%$ and kerosene and liquefied petroleum gas (LPG) at roughly $50 \%$ and $65 \%$ respectively. Currently, more than $20 \%$ of all energy consumed in developing countries is in the form of biomass, with the poorest countries using it to meet $70-80 \%$ of their energy needs, with resulting adverse impacts on health, productivity and deforestation (see the case study on Senegal, prepared by OPEC in Annex 3). In this context, the challenges of phasing out energy subsidies are formidable and deserve to be put into a special perspective with the needs of those economies.

71. Harvesting of biomass can often be reduced by subsidizing LPG in poor countries. Removing subsidies for kerosene or LPG can induce poor households in certain countries to increase their reliance on firewood, increasing deforestation with a consequent negative impact on the environment through higher local pollution and destruction of carbon sinks.

\subsection{Modeling the reform of energy subsidies}

72. Results of the simulation modeling used as the basis for this section and the following ones in this chapter should be interpreted with caution. The proposed modeling is based on the phasing out of all consumer subsidies quantified using price gaps estimated by the IEA for coal, refined oil products, natural gas and electricity, rather than only the inefficient ones that lead to wasteful consumption.

\subsubsection{Economic and sectoral impact}

\section{Macroeconomic impacts of subsidy phase-out}

73. Recent OECD analysis (OECD, 2009) suggests that if countries that subsidize the consumption of fossil fuels removed these subsidies unilaterally, they would record real income gains. This analysis, based on simulations with a computable general equilibrium model (ENV-Linkages), has been updated for this report using as input the most recent price gaps estimated by the IEA for 2008, and considering a gradual phasing-out over the period 2013-2020 , and assuming a neutral recycling back of the budgetary savings from subsidy removal to households as a lump sum payment. On this basis, most countries or regions would realise real income gains from subsidy phase-out. These gains arise from a more efficient allocation of resources across sectors. Therefore, from this perspective, the removal of fossil-fuel subsidies yields both environmental and economic benefits.

74. A different outcome would occur if all countries that subsidize fossil-fuel consumption were to remove these subsidies multilaterally. In this case, terms-of-trade changes associated with a reduction in world energy prices from a drop in demand should lead to a different distribution across countries of real income gains and losses.

75. A multilateral removal of fossil-fuel subsidies in non-OECD countries would depress international fossil-fuel prices. Reflecting assumptions about supply responses, the international prices for crude oil and natural gas are projected to fall by $8 \%$ and $13 \%$ respectively in 2050 relative to the baseline, while the international coal price only drops by $1 \%$, thereby working to offset the impact of reduced subsidies on domestic prices. Combined with relatively low price elasticities, this explains why overall GDP gains at the world level would be small, amounting to just $0.3 \%$ relative to BAU in $2050 .{ }^{15}$

15 This primarily reflects the fact that demand for energy is not very sensitive to price, so that the distortive impact of energy subsidies and the gain from their removal would be limited. An additional explanation for the small magnitude of world real income gains is that the fall in world fossil-fuel prices 
76. International fossil-fuel price declines induced by phasing out of consumer subsidies would induce terms-of-trade changes that would favor fossil-fuel importing countries at the expense of fossil-fuel producers. While a multilateral removal of fossil-fuel subsidies would bring some real income gains at the world level, these gains would be unevenly distributed across countries (Fig. 3.1). For a number of countries, phasing-out fossil fuel subsidies would lead to a real increase in GDP relative to the baseline, both from efficiency gains associated with the removal of the subsidies and from an improvement in terms of trade. Some oil-importing OECD countries will also report real income gains by around $1 \%$ as their terms-of-trade improve. Most fossil-fuel producing countries are projected to incur real income losses that are substantial in some cases, such as for Russia and the non-EU Eastern European countries.

Fig. 3.1: Long term impact on GDP of a multilateral phasing out of fossil-fuel subsidies by regions in 2050 (percentage changes indicate GDP change in 2050 relative to the baseline)

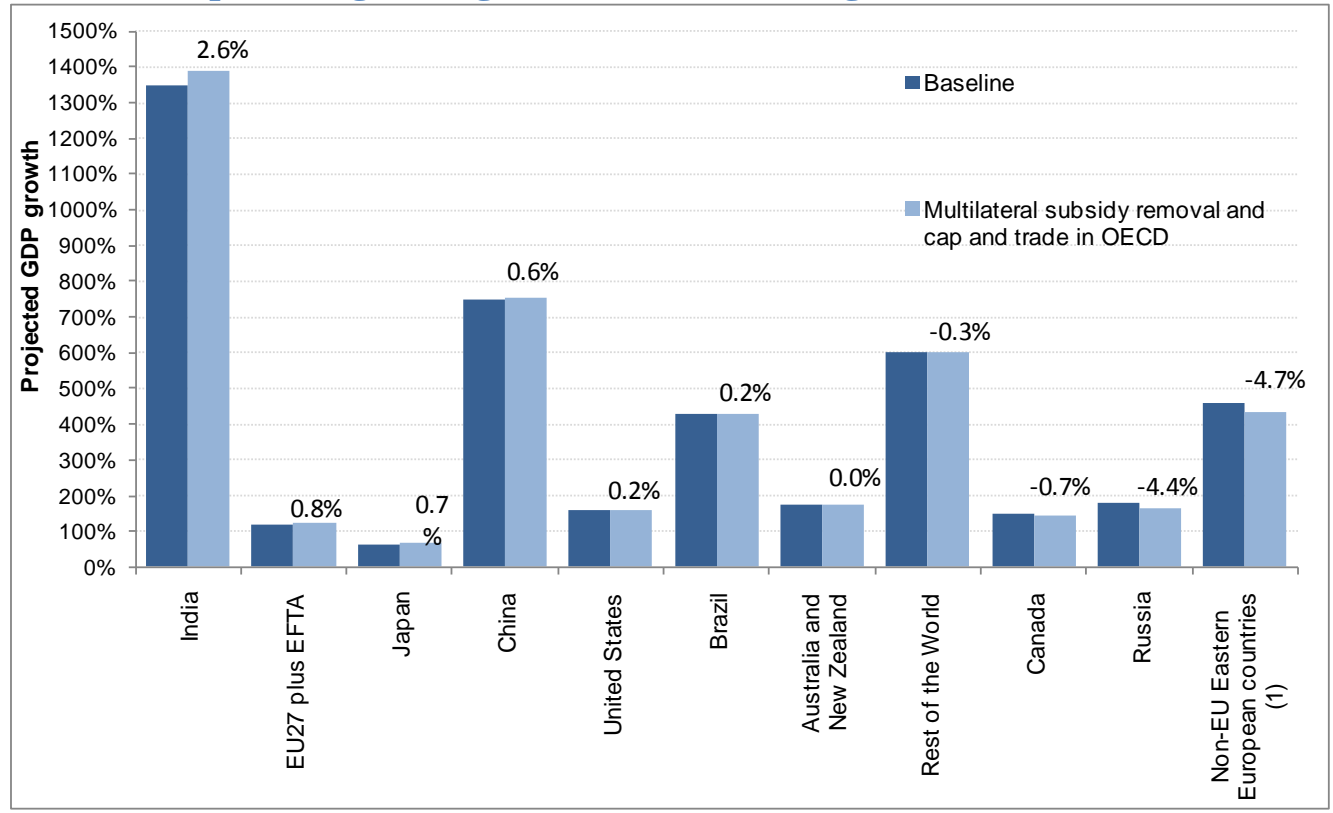

Source: OECD ENV-linkages model based on IEA subsidies data (OECD, 2010a)

Note: Non-EU Eastern European countries include Armenia, Azerbaijan, Belarus, Croatia, Georgia, Kazakhstan, Kyrgyzstan, Moldova, Tajikistan, Turkmenistan, Ukraine, Uzbekistan, according to the data aggregation in the GTAP database.

\section{Impacts on the energy sector and energy demand}

77. Based on the IEA's analysis, the phase out between 2011 and 2020 of the consumption-related fossil-fuel subsidies would cut primary global energy demand by $5.8 \%$ by 2020 , compared with a baseline in which subsidy rates remain unchanged (Fig. 3.2). This is equivalent to the current energy consumption of Japan, Korea and Australia combined. Furthermore, ongoing reductions in global energy demand relative to the baseline would be realized post-2020.

78. The IEA modeling takes into account the so-called "rebound effect" which would offset some of the savings realized through a subsidy phase-out program (i.e. as energy prices are lower in the phase-out scenarios due to lower overall demand, some consumers have a reduced incentive to consume energy efficiently).

induces producers to reduce their supply, leaving more of their reserves in the ground. This leads to a GDP reduction in the medium term, all other things being equal. 
Fig. 3.2: Impact of subsidy phase-out on global energy demand

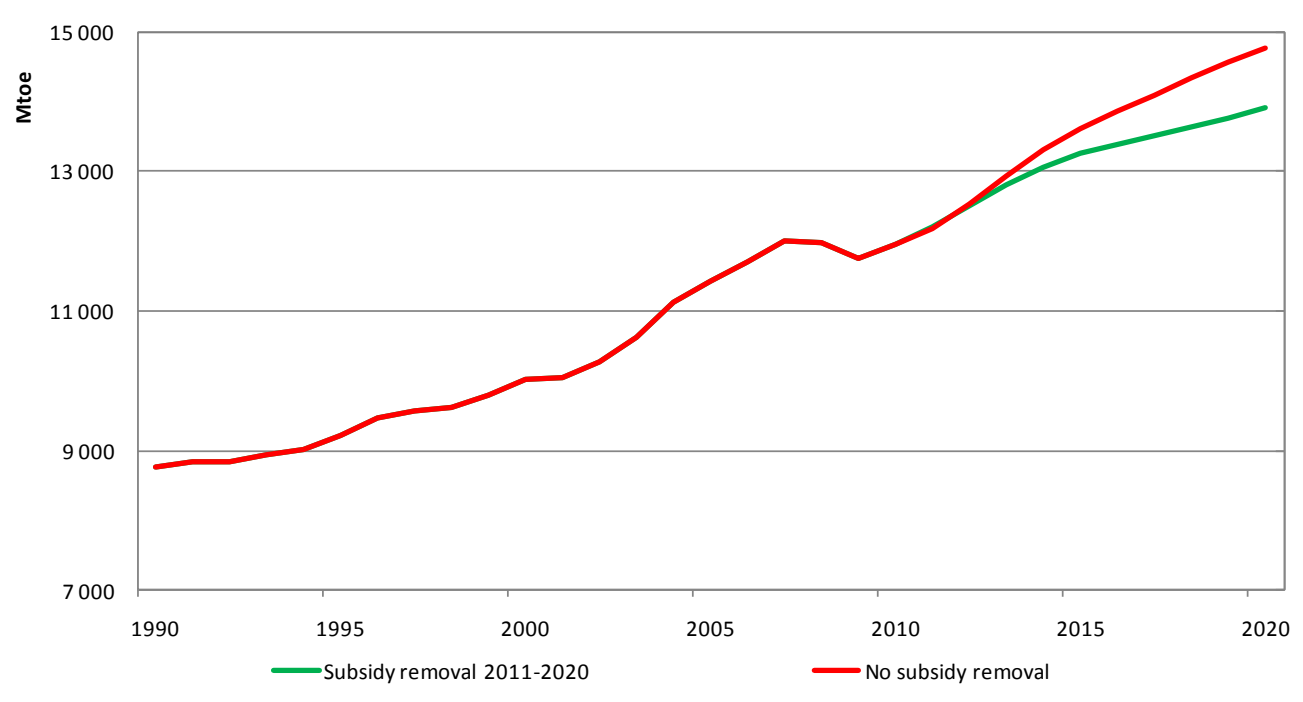

Source: IEA(2010)

\subsubsection{Social and equity impact}

79. Worldwide, about 1.5 billion people lack access to electricity services (Fig. 3.3). In addition, nearly 2.5 billion continue to use traditional biomass fuels for cooking and heating (IEA, 2009). IEA analysis indicates that universal electricity access could be achieved with additional power-sector investment of US\$ 35 billion per year in 2008-2030.

Fig. 3.3: Number of people without access to electricity today and projected in 2030 (millions)

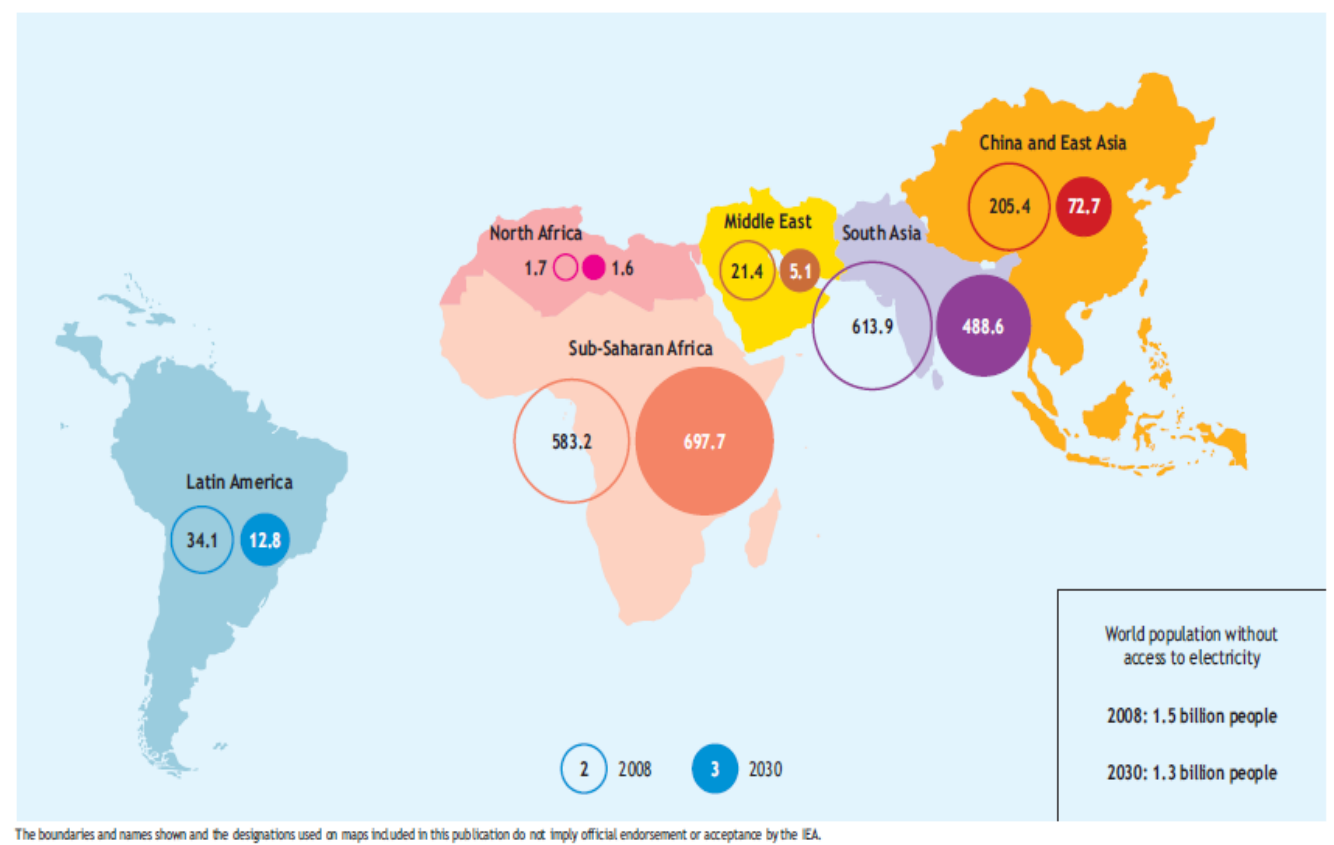

Source: IEA (2009).

80. Because certain energy forms, such as kerosene, LPG and electricity, are recognized as more necessary to support the basic needs of the poor than others, there is concern that 
the phase out of corresponding subsidies would serve to increase poverty and be detrimental from an equity standpoint (see Annex 2 prepared by IEA). However, the phase out of subsidies to these fuels would not accrue significant benefits in terms of reduced demand and improved efficiency or a reduction in emissions, relative to the benefits accrued through the phasing out of subsidies to other fuels such as gasoline, diesel and natural gas. Nonetheless, numerous studies have shown that most existing subsidy programs for these fuels could be made more cost-effective through better targeting.

81. A phase-out of consumption-related subsidies for fossil fuels would generate large budgetary savings, implying that such subsidies could be replaced by a direct and, if appropriate, larger transfer to households. The OECD analysis described in Section 3.2.1 suggests that the suppression of subsidies would lead in 2020 to extra government revenues equal to almost $6 \%$ of GDP in Russia, $1.8 \%$ in India and $0.4 \%$ in China. Alternatively, the freed funds could be used to reduce other distorting taxes, which would increase the real income gain from subsidy removal, or to reduce poverty in a more targeted and efficient way than through a universal subsidy to fossil-fuel consumption.

82. Whether cash transfer programs can be efficiently implemented depends very much on the institutional setting and the administrative capability of individual governments. While the poor need to be compensated for the loss of household income associated with the removal of fossil-fuel subsidies, the absence of safety nets in many developing economies means that this objective cannot be easily achieved. Developing a well-targeted safety net can take many years and certain sections of society may still not be reached. The removal of fossil-fuel subsidies in developing countries should not therefore be considered as having little or no welfare cost. Indeed, energy price subsidies may represent a second-best solution in certain cases, although other types of subsidies - to goods consumed primarily by the poor - are likely to be inherently better targeted.

\subsubsection{Environmental impact}

\section{Short-run impacts on GHG and other emissions}

83. Based on IEA analysis, the phase out between 2011 and 2020 of the consumptionrelated subsides in the countries covered in its dataset would cut global energy-related carbon-dioxide $\left(\mathrm{CO}_{2}\right)$ emissions $6.9 \%$ by 2020 , compared with a baseline in which subsidy rates remain unchanged (Fig. 3.4). This amounts to $2.4 \mathrm{GT}$ of $\mathrm{CO}_{2}$ which is equivalent to the current emissions of France, Germany, Italy, Spain and the United Kingdom combined.

84. The savings identified by the IEA analysis arise as the price signal resulting from subsidy phase-out would provide a clear incentive for consumers to use energy more efficiently and trigger a degree of switching from fossil fuels to other fuels that emit little or no GHGs. These projections take into account emissions that result from any fuel switching that occurs as a result of subsidy phase-out. Consistent with a widely-accepted carbon accounting convention, for modeling purposes biomass is considered to be carbon neutral on the basis that the growing of biomass would remove as much $\mathrm{CO}_{2}$ as is emitted during its combustion. ${ }^{16}$

85. In addition to reducing carbon dioxide emissions, IEA analysis indicates that subsidy phase-out would have other important co-benefits for the environment. Reduced demand growth for fossil fuels would in particular lead to lower emissions of air pollutants such as $\mathrm{SO}_{2}$, $\mathrm{NO}_{\mathrm{X}}$ and particulate matter which are harmful to human health and cause environmental problems, such as acid rain.

16 Such an assumption ignores inter-temporal effects. In particular, when there is net deforestation more $\mathrm{CO}_{2}$ may be released into the atmosphere than would be re-absorbed in the same year. Indeed, if carbon soil is lost, it may take many years for the released carbon to be re-absorbed into living biomass. 
Fig. 3.4: Impact of subsidy phase-out on energy-related carbon dioxide emissions

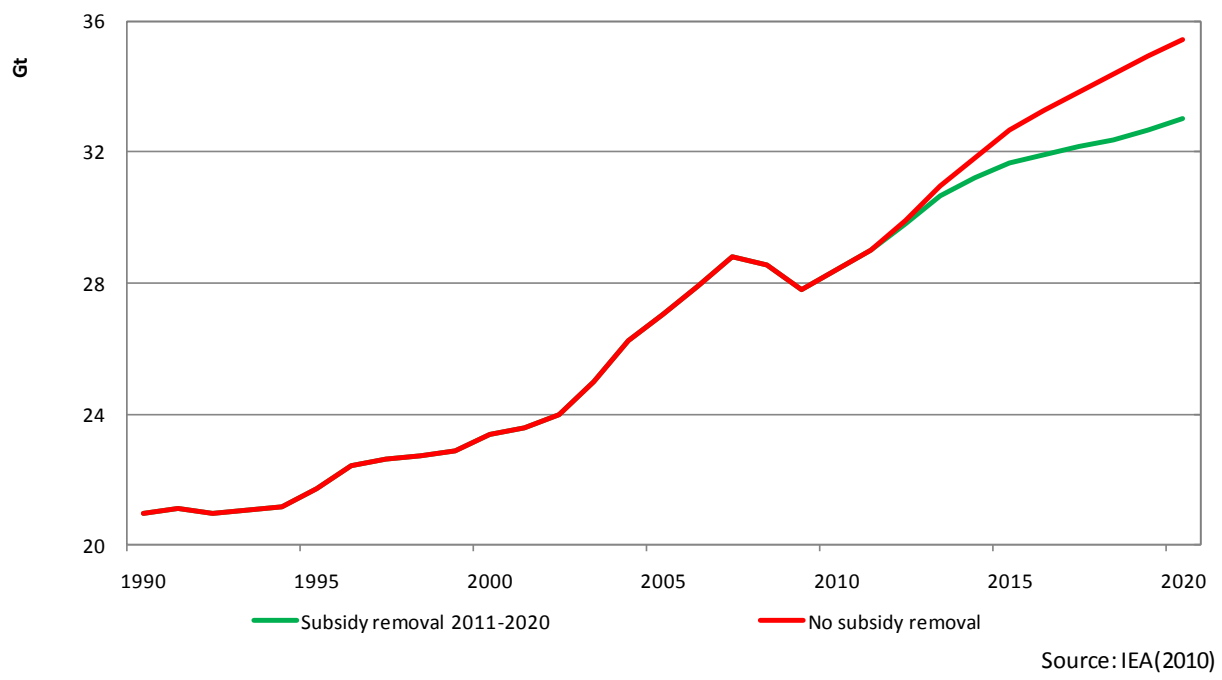

86. Even marginal shifts from fossil fuels to renewable energy could accelerate learning and declines in their unit production costs. Higher prices of vehicle fuels (incorporating pricing of local externalities) could lead over the long run to more efficient urban structures, with possible benefits for economic growth. Reduced fiscal burden on the government could allow for increased growth-accelerating investments in such areas as education.

\section{Long-run impacts on GHG emissions}

87. Recent OECD analysis (OECD, 2009) provides further evidence on the environmental benefits of removing fossil-fuel energy subsidies. This work, which was updated using IEA 2008 price-gap estimates, suggests that a gradual multilateral removal (by 2020) of existing energy subsidies in non-OECD countries would lead to a substantial drop in GHG emissions from fossil-fuel combustion by 2050 in some countries or regions, amounting to more than 20\% in non-EU Eastern European countries, Russia (Fig. 3.5). The subsidy removal could result in global GHG emissions of $10 \%$ by 2050 relative to the baseline - if OECD countries abide by the emission caps announced in the context of the Copenhagen Accord. A failure by OECD countries to abide by caps would result in carbon leakage, whereby an estimated $16 \%$ of the emission reduction achieved in non-OECD countries would be offset by an increase of emissions in OECD countries (Box 3.1). 
Fig. 3.5: Long-term impact of a multilateral phasing-out of fossil fuel subsidies on GHG emissions

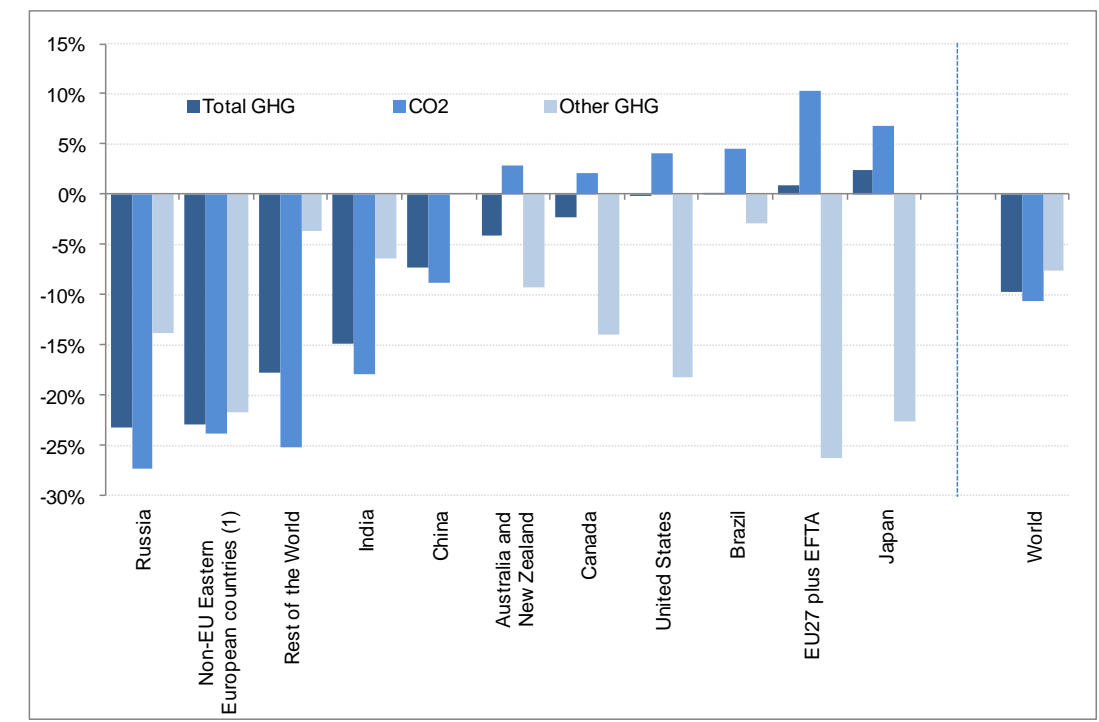

Source: OECD ENV-linkages model based on IEA subsidies data (OECD, 2010a)

Note: Non-EU Eastern European countries include Armenia, Azerbaijan, Belarus, Croatia, Georgia, Kazakhstan, Kyrgyzstan, Moldova, Tajikistan, Turkmenistan, Ukraine, Uzbekistan, according to the data aggregation in the GTAP database.

88. The removal of fossil-fuel subsidies would also contribute to reductions in other greenhouse-gas emissions, although by a lesser extent than $\mathbf{C O}_{2}$ emissions $(7 \%$ in 2050 relative to the baseline compared with $11 \%$ for $\mathrm{CO}_{2}$ emissions; see Fig. 3.6). This illustrates the complementarities across gases and appears as an additional benefit of subsidy removal. A large share of this reduction would be achieved in OECD countries in order to meet their emission caps, resulting in reductions of non- $\mathrm{CO}_{2}$ greenhouse gases by more than $20 \%$ in Japan and the EU. ${ }^{17}$

89. The emissions reductions achieved at the world level by removing subsidies are extremely robust with respect to changes in the price-gap estimations by the IEA between 2005 and 2008. The two main sources of uncertainty for the results are the value of elasticities of supply for fossil fuels and future mitigation policies in developed countries (see Box 3.1 and the Background Paper "An Overview of the OECD ENV-Linkages model" provided by the OECD).

17 The cap on OECD emissions is applied at the OECD level, allowing for some emissions trading among OECD countries. The carbon price needed to achieve this cap is low enough to be offset by the induced fall in international fossil-fuel prices. As a result, $\mathrm{CO}_{2}$ emissions increase in OECD countries and the cap is achieved by reducing emissions of greenhouse gases other than $\mathrm{CO}_{2}$. 


\section{Box 3.1 Robustness of impact on emissions to alternative assumptions}

In quantifying the impact of subsidy removal on GHG emissions, uncertainty arises from three different sources.

1. Country coverage and methodological assumptions: As discussed in the Chapter 2 (see Box 2.1), there are caveats on the choice of the reference price, especially with regards to electricity. In addition, to the extent that adjusted world-market prices are used as reference prices, price gaps vary over time, reflecting the changes in the international prices of fossil fuels and in the pricing policies of individual countries in their domestic markets. The IEA has estimated price gaps in 2005 and 2007 for 20 non-OECD countries, amounting to roughly $40 \%$ of world energy consumption. More recently, the IEA has estimated price gaps in 2008 for an extended sample, including 2 OECD countries (Korea and Mexico) and 35 non-OECD countries, using a somewhat different methodology. Despite differences in years, country coverage and methodology, the emission reductions achieved at the world level by removing these subsidies is extremely robust (see Table below) and always very close to $10 \%$ in 2050 , although there are some differences at country or regional levels.

2. Context of implementation: The central scenario discussed in the main text quantifies the impact of subsidy removal in a context wherein emissions in countries with no subsidy reform cannot exceed a given level, as would be the case if these countries apply the emission targets they have declared after COP15. In the absence of these caps, emissions in these countries should increase, sometimes substantially as in the EU, reflecting the existence of carbon leakages. These leakages amount to respectively $22 \%$ and $16 \%$ in 2020 and 2050 of the emission reduction achieved by removing subsidies in the countries included in the 2008 price-gap database. Accordingly, the world emission reduction would be smaller: $8 \%$ instead of 10\% in 2050 (see Table).

Table: World GHG reductions and real income changes in 2020 under different assumptions

$\%$ deviation from the baseline of total GHG emissions and real income, different simulations

\begin{tabular}{|c|c|c|}
\hline \multirow[b]{2}{*}{ Simulation } & \multicolumn{2}{|c|}{$\%$ deviation from the baseline } \\
\hline & $\begin{array}{c}\text { Total GHG emissions } \\
2050 \\
\end{array}$ & $\begin{array}{c}\text { Real Income } \\
2050 \\
\end{array}$ \\
\hline $\begin{array}{l}\text { Central scenario: multilateral removal of fossil fuel subsidies together with a cap } \\
\text { on emissions in remaining countries }{ }^{1}\end{array}$ & $-9.8 \%$ & $0.3 \%$ \\
\hline Central scenario without emission cap in remaining countries & $-8.2 \%$ & $0.3 \%$ \\
\hline Same as in central scenario but using IEA 2005 price gaps & $-10.2 \%$ & $0.1 \%$ \\
\hline Same as in central scenario but using IEA 2007 price gaps & $-9.9 \%$ & $0.2 \%$ \\
\hline Central scenario with higher fossil fuel supply elasticities & $-11.3 \%$ & $0.2 \%$ \\
\hline Central scenario with lower fossil fuel supply elasticities & $-7.9 \%$ & $0.5 \%$ \\
\hline \multirow[t]{2}{*}{ Central scenario with inelastic fossil fuel supply } & $-1.8 \%$ & $0.8 \%$ \\
\hline & 2020 & 2020 \\
\hline Declared targets $^{2}$ and no fossil-fuel subsidies phasing-out & $-10.4 \%$ & $-0.5 \%$ \\
\hline Declared targets ${ }^{2}$ together with fossil-fuel subsidies phasing-out & $-12.3 \%$ & $-0.4 \%$ \\
\hline Ambitious declared $\operatorname{targets}^{3}$ and no fossil-fuel subsidies phasing-out & $-14.4 \%$ & $-0.6 \%$ \\
\hline Ambitious declared targets ${ }^{3}$ together with fossil-fuel subsidies phasing-out & $-15.8 \%$ & $-0.5 \%$ \\
\hline
\end{tabular}

1) Emissions in OECD countries and in Brazil are capped to their baseline levels in order to avoid carbon leakages 1) Emissions in OECD countries and in Brazil are capped to their baseline levels in order to avoid carbon leakages
2) Minimum emissions reduction targets that countries declared following COP15 (e.g. EU target of a $20 \%$ emissions reduction from 1990 levels
by 2020). by 2020).

3) Most ambitious emissions reduction targets that countries declared (e.g. EU target of a 30\% emissions reduction from 1990 levels by 2020 ).

Source: OECD ENV-Linkages model based on IEA subsidies data.

In order to put these emission reductions at the world level into perspective, the Table also reports the world emission reductions that could be achieved in 2020 if countries were to apply the emission targets that they have declared after COP15 (bottom panel of the Table). Subsidy removal could account for a third to a fifth of the reduction effort implied by these targets implementing these targets while, at the same time, removing fossil-fuel subsidies would yield higher emission reductions in 2020, achieved at lower cost.

3. Values of fossil fuel supply elasticities One of the largest uncertainty sources is related to the assumed values of the fossil-fuel supply elasticities. The central scenario is based on the assumption that the supply of coal is much more elastic than the supply of crude oil and natural gas. As illustrated in the Table, lower supply elasticities result in lower emission reductions because a larger proportion of the domestic fossil-fuel price increase from the subsidy removal is offset by a fall in the corresponding international prices. ${ }^{1}$ In the extreme case of completely inelastic fossil-fuel supplies, the environmental benefit of the subsidy removal becomes negligible while the economic gains at the world level are larger.

1. Alternatively, if emissions are not capped in countries where there is no subsidy reform, because carbon leakages offset a large proportion of the emission reductions achieved by the subsidy removal. 


\section{Suggestions for Implementation}

\subsection{A Roadmap for policy makers}

90. This chapter provides a roadmap to guide policy makers in implementing fossil-fuel subsidies reforms, based on lessons drawn from case studies in developed and developing countries. Particular attention is devoted to how to identify those subsidies that should be phased out, to address implementation challenges (including overcoming policy obstacles and affordability constraints), and to facilitate the reform process through the use of targeted assistance, safety-nets and industrial restructuring packages. The challenges in reforming both consumer and producer subsidies are addressed.

91. A necessary first step in implementing the reform of fossil-fuel subsidies is identifying those subsidies that should be phased out because they are inefficient and lead to wasteful consumption. Identifying which specific fossil-fuel subsidies are "inefficient" and "encourage wasteful consumption" from among the universe of energy subsidies that are provided by individual countries requires understanding the circumstances of each country, and analysis of the impact of the subsidy on consumption.

92. A simple decision tree or checklist could be developed and used by individual countries to rationalize and phase-out selected subsidies over the medium term. As suggested by the World Bank, the following tests can be used to assess whether to retain, redesign or remove an energy subsidy at each phase of the decision tree summarized in Figure 4.1. The first two phases consider the impact of existing energy subsidies in order to help policy makers identify those inefficient subsidies that lead to wasteful consumption, considering both efficiency and equity issues. The final two phases assess the cost effectiveness of the subsidy tools compared with alternative ones and more broadly in the context of other policy objectives.

93. The economic concept of efficiency in this context refers to the adequacy of the given energy subsidy policy tool to reach the intended objectives for which they were introduced (e.g. to protect the poor).

- Phase 1 Questions: Is the original rationale for the subsidy (e.g. protecting the poor) still valid? Has the subsidy succeeded in achieving its objective(s)? If the answer to either of these questions is negative, subsidies need to be phased out. If the answer to both questions is "yes" subsidies can be further distinguished into the two categories below, after undertaking costbenefit analysis. If net benefits are positive (e.g. benefits more than outweigh the costs, including local environmental damages), subsidies may not need to be phased out. However, they need to be subject to the test of phase 2 to ensure that they do not encourage wasteful consumption. If the net benefits are negative, subsidies should be considered for phase out, while reaching the intended objective (e.g. protecting the poor) with more cost effective instruments (Phase 3).

94. Energy subsidies become wasteful when they result in excessive energy consumption by households and industries compared with the situation in the absence of subsidies. The increased consumption due to the subsidies (through the channels discussed in Chapter 3) must be further analyzed to disentangle to what extent it has been used to satisfy basic needs (basic heating in cold seasons as opposed to superfluous air conditioning). This requires moving the analysis from pure efficiency to social and equity considerations. The appropriate threshold must be defined at the national level, depending on countries' circumstances (for households the level of subsistence can represent a useful point of reference).

- Phase 2 Questions: Have subsidies substantially increased consumption by households and industries? Subsidies that have limited impact on energy consumption are not in urgent need to be phased out. Subsidies that lead to excessive energy consumption can be further 
distinguished into the two categories, after comparing actual consumption related with basic need levels. If the increase of consumption is not wasteful in that it satisfies basic needs, subsidies can be kept, subject to continuous monitoring. If the increase in consumption does not relate to basic needs and is wasteful then energy subsidies need to be phased out.

Figure 4.1: Decision tree

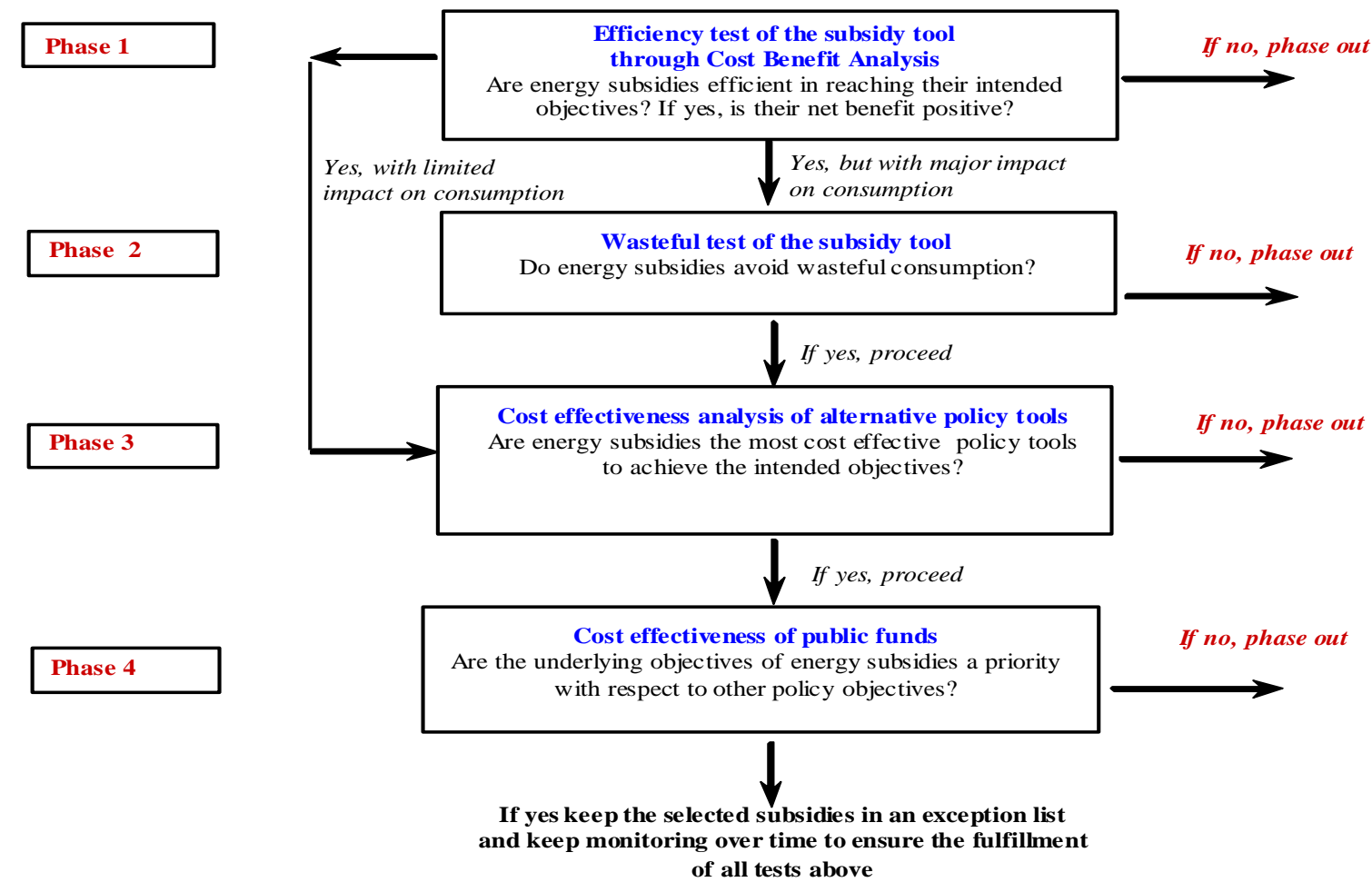

Source: Background Paper "Phasing out energy subsidies: adecision tree and evidence from case studies, prepared by the World Bank (forthcoming, 2010)

95. Further redesign or fine tuning of energy subsidies may be needed to ensure that they are cost-effective. In addition, such an assessment must take into account all the possible alternative uses of public funds. The G-20 reference to the term "rationalize" suggests that some subsidies could be retained, provided that their design can be enhanced to better reach their intended policy objectives. The subsidy re-design may include, for example, better targeting or the introduction of alternative or complementary policies. Regardless of such enhancements in design, regular monitoring and evaluation of subsidies is strongly recommended. Section 4.3 considers in more detail the case of alternative policy tools to protect the poor, including cash transfers.

- Phase 3 Questions: Can the same objectives be reached by alternative policy tools in a more cost-effective way? The full answer to this question requires undertaking a social cost-benefit analysis (SCBA), comparing the benefits of the subsidies with the social and local environmental costs. A fully fledged SCBA would require attaching monetary values to these impacts and then determining whether benefits exceed costs and by how much (section 1.5). In the absence of a monetary valuation of impacts, cost-effectiveness analysis, which identifies the cost of bringing about a given impact, using alternative policy instruments to subsidies, can be recommended, as suggested in Figure 4.1.

- Phase 4 Questions: For those fossil fuel subsidies that remain, it is then necessary for policymakers to consider the subsidies in the context of broader policy objectives. That is, whether the opportunity cost of energy subsidies is too high, particularly in the presence of alternative policy priorities. Can the same amount of money be reallocated to other more 
socially desirable activities? The analysis would require comparing at the margin the welfare impact of a unity reduction of energy subsidy compared with an increase in expenditure on health, education or infrastructure. For example, if the policy makers' priority, due to international agreements, is to reduce GHG emission, then the global impact of each of the energy subsidies on the environment should be carefully quantified, where possible in monetary value. Alternatively, the welfare benefit of subsidies could be compared with the marginal cost of public funds.

96. It is also important to note that, even in the case of relatively "efficient" subsidies that are not in urgent need to be phased out scrutiny, periodic review and monitoring is needed to ensure that they continue to pass all the tests described above.

97. In the context of work on the phasing out of environmentally harmful subsidies, the OECD has developed a checklist where the focus is on identifying subsides whose removal would benefit the environment (OECD, 2003 and 2005). This has been applied to the analysis of a range of subsidies in several European countries, including Poland, Hungary, Germany and the Czech Republic, as well as in a major recent European Commission-sponsored project (see, for example, Meyer and Meyer, 2009; IEEP, 2007).

98. Having identified which particular subsidies need to be reformed, governments need to address the obstacles to reform and identify mechanisms for overcoming resistance to changing the subsidy. They have an array of techniques for doing this for both consumer and producer subsidies, each of which has advantages and disadvantages that need to be balanced in making a choice as to how to proceed.

\subsection{The Political Economy of Phasing out Inefficient Energy Subsidies}

99. Even if the removal of existing subsidies leads to overall welfare gains and thus can be recommended from an economic point of view, practical design and implementation of subsidy reforms have to take into account the challenges of political economy and social considerations. These include recognizing and responding to: (i) opposition to reforms by negatively affected stakeholders; (ii) a potentially low level of public trust in the reform agenda; (iii) lack of information about the benefits of subsidy reform among concerned parties; and (iv) constraints relating to institutional and administrative capacity.

100. A key challenge is that the benefits of subsidy removal are diffuse, whereas the potential losses from reform tend to be concentrated in powerful groups likely to oppose subsidy reform (Victor, 2009). Depending on the political influence exerted by these groups, this can impose significant constraints on decision makers. Affected groups need to be identified, informed in a timely fashion, and appropriately compensated if necessary to prevent economic and social hardship.

101. Similarly, groups benefitting from subsidy reforms must be identified and informed to gain political support and momentum for the reform agenda (Box 4.1). This is particularly important if beneficiaries of subsidy reforms face difficulties in coordinated action because they are relatively dispersed, have limited access to the political decision-making process, or are unaware of the effects of energy subsidies and the potential benefits from subsidy reforms. 


\section{Box 4.1: Communication and Compensation Strategies for Subsidy Reform}

- Communication campaigns can act to build public support in several ways:

- Public acceptance is more likely if the rationale is explained in advance.

- Early publicity may prevent some groups from hiding their self-interest by making wild claims. Coalitions of public support may be needed to offset opposition from interest groups who benefit from the subsidies that are due to be abolished.

- However, communication alone is unlikely to be sufficient, especially for the poor, for whom compensation packages can serve to protect them from hardship, and to overcome wider perceptions of inequity. Amongst richer households, compensation can both buy support and deflect accusations that reforms are unjust. For producers, the prospect of support for fossil-fuel subsidy reform may be improved with the design of well-targeted compensation and restructuring measures.

- Each compensation and communication package needs to be tailored to the specific political and economic circumstances. It is particularly important that they key stakeholders are identified, and their concerns and needs addressed.

- Relevant stakeholders and special interest groups may include the poor (particularly the unemployed or unemployable), labor representatives, who fear cuts in real wages and oil intensive industries, or professions such as taxi or truck drivers, which rely on cheap fuel products.

- Stakeholders will vary from country to country and it may prove impossible to compensate everyone of losses. The poor always represent a key constituency, both on equity considerations and because price rises could give rise to desperation and unrest.

- Compensation packages can also be used to provide time-limited industry restructuring or transition assistance for sectors particularly affected by subsidy reforms. For example, the compensation package in Jordan also provided special provisions for public sector employees and small business owners.

Source: IEG/World Bank (2009), Bacon et al. (2010, forthcoming)

102. Increasing the availability and transparency of energy subsidies data is essential in overcoming some of the challenges related to reform. First, improved data on the scope and nature of fossil-fuel subsidies can be useful in dispelling myths and misinformation about the magnitude and incidence of fossil fuel subsidies. Likewise, it can encourage informed discussion and debate among those with an interest in maintaining the subsidies and those interested in their reform. Ensuring transparency of subsidy data can also encourage a concise and consistent presentation of subsidy information and facts. Finally, and perhaps most importantly, subsidy data collection and transparency can promote peer review and encourage compliance with any future subsidy reform processes (Hale, 2008; Laan, 2010). Household-expenditure surveys and industry performance reviews can be powerful tools to provide information on those benefiting from the existing subsidy and the impacts on the various groups from subsidy removal, providing an important reference for assessing the adequacy of compensation measures that are planned.

103. An important condition for successful subsidy reform is the credibility of the government's commitment to compensate vulnerable groups for energy-price increases, and, more generally, to use the freed public funds in a beneficial way. Governments need to ensure public trust in the reform agenda through broad communication, and appropriate timing of subsidy removal and implementation of compensatory or mitigating policies. For example, the reform of coal subsidies in Germany, Poland and the UK was accompanied by extensive communication campaigns as well as significant compensation for displaced workers and support for regional economic development.

104. Subsidy reform appears to be possible in situations where the fiscal costs to the government are so serious that the government has no choice but to act. This gives the political willpower to make reforms succeed. In many cases, a major driver of energy-subsidy 
reforms was the escalating costs of oil that made the fiscal cost of subsidies unsustainable. This was the case for European countries that introduced high fuel taxes after the 1974 and 1979-1980 oil-price rises. In the recent case of Jordan, reforms were driven by the fact that Iraqi oil, on which it depended, became too expensive.

105. The timing of reforms is also crucial to gaining support for change. Phasing out subsidies is a process that often, but not always, takes place over a long period of time, and depends on individual countries and their specific circumstances. Any transition path needs to be carefully planned and laid out to avoid social unrest. The rate at which OECD countries succeeded in phasing out coal subsidies varied considerably, for example. In the case of the UK, Belgium and the Netherlands, the closing down of mining was carried out quickly, accompanied by social assistance and job training for unemployed coal miners. In other countries, such as Spain and Germany, the phasing out of subsidies has been relatively slow. Developing countries also present mixed evidence, with several instances of reversals of reforms. Jordan succeeded in phasing out its fuel subsidies over a four-year period, reducing energy subsidies from 5.9\% of GDP in 2004 to $0.8 \%$ in 2008 .

106. Subsidy reforms are more likely to be accepted if accompanied by broader reforms, including regulatory reforms and increased partnership between the public and private sector. The process of coal reform in the UK was part of a broader reform process that involved regulatory reform across the economy. There was also a major focus in the reform process on ensuring that the private coal and energy companies were able to be financially viable in the future without government support. In the case of developing countries, consumers have been willing to pay higher prices in exchange for an improvement in the quality of the service, such as occurred in many countries including Bosnia Herzegovina and Armenia. However, in other cases, initially implemented tariff increases have been rescinded, as the cases of Argentina and Moldova illustrate. In the case of Argentina tariffs were frozen after the financial crises in 2002 and 2008, well beyond the emergency period of the crises.

107. In poor countries, another factor that may facilitate political support for reform of subsidies is the community's desire to see their economy develop beyond being just a supplier of food and raw materials. Many energy-exporting countries have used their domestic resources to promote energy-intensive industries (e.g. petrochemical, aluminium), to expand their industry base, diversify the economy, and provide employment. Such a desire to diversify the economy beyond supplying raw material has played an important role in the provision of fossil-fuel subsidies not only in Eastern European countries, but also in China and India (Anderson 1995). Where fossil-fuel subsidies are seen as an integral part of an economic development strategy, other measures to enhance growth and alleviate poverty may need to be implemented.

108. Past international assistance has been made contingent upon structural reforms, including a reduction in subsidy bills. Subsequent energy price increases, in the early and mid 1980s, were typically announced with short notice, and with limited attempts to explain the rationale behind the changes. Social unrest was a common response: violence and protests followed price rises in Egypt (1977), Morocco (1981, 1984), Tunisia (1984), and Jordan (1989, 1996). In many cases (Tunisia 1983, Morocco 1981, Egypt 1977), price increases had to be reduced or rescinded. These experiences continue to inform policy making today: governments now take far more care to communicate the detail and reasoning behind reforms, and to target compensation to key constituencies (see Box 4.1).

\subsection{Policy Tools to Address Distributional Issues}

109. There is a range of policy tools available to governments to address the distributional issues associated with fossil-fuel subsidy reform, including the issues associated with both producer and consumer subsidies. This section reviews the relevant experiences and key features of the tools 


\section{Assistance for economic restructuring and industry transition}

110. Fossil-fuel subsidies provided to producers (either to industry or to electricity generation) generally become embedded in the operations of the companies. Gaining political support to reform such subsidies therefore requires careful design of the reform process to ensure that firms are able to adapt to the new economic circumstances. In addition to providing transparent and timely information about the expected impacts of the reform, governments may also wish to provide temporary and targeted assistance for affected firms to, for example, restructure their operations, exit the industry, or adopt alternative technologies. Assistance to affected workers may be part of such packages and could include initiatives for worker retraining or relocation, or the provision of incentives to diversify the regional economic base.

111. Recent reforms to coal subsidies in a number of European countries provide examples of how governments have addressed these distributional concerns in the past few decades (see Annex 3 prepared by OECD, OPEC and World Bank). As mentioned in section 4.2, reforms of coal subsidies in Germany and Poland were accompanied by social assistance related to the closure of mines and, in the case of Poland, generous severance packages for affected workers. Reforms to the UK coal mining industry were initially imposed with little adjustment assistance, leading to problems such as high unemployment and poor health in the affected regions. However, in 2000 , the UK government began providing some financial support to assist the remaining parts of the coal industry adjust their operations to be able to enter into commercially realistic investment projects that maintain access to coal reserves, provide employment opportunities in disadvantaged areas, and create an enabling environment for the development of alternative economic opportunities in coal-mining areas.

112. In general, it is necessary that any assistance for economic restructuring or industry adjustment in response to subsidy reform be well-targeted, transparent and time-bound. A package approach is required to ensure that the distributional impacts on all affected parties (both companies and individual workers and communities) are addressed. This is an important component of the process of gaining support for subsidy reform.

\section{Policy Tools to Protect the Poor}

113. There is a wide range of policy tools to protect the poor. These types of programs are known collectively as safety nets, or social-assistance transfers. Direct transfers include cash benefits or near-cash transfers such as vouchers or smart cards. Indirect transfers include fee waivers to help households maintain access to essential services such as health, education, heating or transportation, or lifeline tariffs for electricity or natural gas.

114. Cash transfers have several advantages. They distort markets and incentives less than other programs, and they can be targeted at poor households or other groups. In contrast with universal subsidies, their cost to the government budget is much lower (some of the better known and effective programs spend around $0.5 \%$ of GDP) and is known with certainty. Their administrative cost, although higher than those of universal subsidies, is lower than the administrative cost of most other programs. Near-cash transfers share most of the advantages of cash transfers, but their administrative cost is usually higher. Voucher schemes ${ }^{18}$ are more difficult to administer because they require timely compensation of the fuel retailer or service provider willing to sell the product or service at a discounted price.

18 Voucher schemes (i.e., discounted coupons) entitle the designated households to receive a limited supply at a subsidized price. As a variant of this approach, households are issued cards certifying that they are below the poverty line, qualifying them to purchase certain quantities of goods commonly used by the poor at subsidized prices, including a cooking or lighting fuel. 
Fig. 4.2. Targeting Accuracy of Specific Poverty-Focused Assistance Benefits

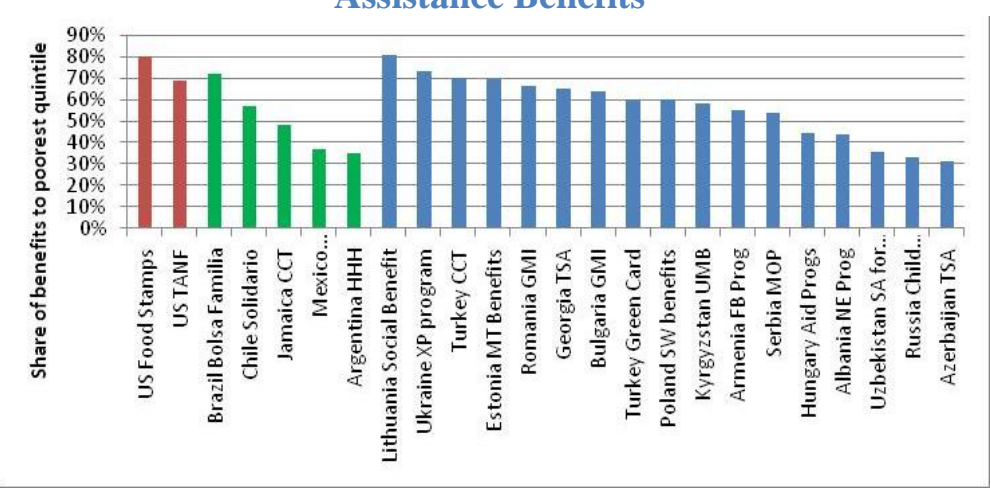

Source: World Bank staff computations based on households survey data (2005-2008)

115. When properly implemented, targeted cash or near-cash programs succeed in transferring most of their funds to the poor. Out of twenty-four countries surveyed in the period 2005-2008, sixteen were transferring more than 50 percent of the funds to the poorest 25 percent of the population (Fig. 4.2). However, the design and implementation of targeted transfers can be challenging. Their effectiveness and efficiency depend on the targeting method and administrative capacity, including capacity to reach the intended beneficiaries and distribute the benefits reliably. If capacity or institutional infrastructure is not present, the programs may be exposed to significant errors, such as excluding a significant share of the poor, or including a large share of the non-poor.

116. When more complex and better-targeted mechanisms are unavailable due to institutional constraints, some governments have used energy subsidies as a simple tool to redistribute wealth. Well-targeted redistribution and poverty-reduction policies require adequate institutional and administrative capacities that may not be available. Governments willing to reform subsidy programs but lacking these capacities need to be supported in their efforts to build institutional capacity necessary for implementing and maintaining social safety nets and alternative instruments for poverty reduction.

\section{Targeting Subsidies to the Poor}

117. Fossil-fuel and electricity subsidies, in some contexts, have helped to eradicate extreme poverty in developing countries and in that regard they may have been a relatively successful tool. However, in many instances, there is scope to ensure that the subsidies are bettertargeted, reach the truly non-poor inhabitants of a country, and are the most appropriate tool for achieving the poverty reduction objectives (especially as the economy of a country evolves over time) .

118. Better targeting can usually be achieved with any subsidy program. Rationing can limit the total cost of a subsidy program, but it establishes a two-tier price system, with the risk that supplies earmarked for sale at lower prices are diverted to a more profitable open market or that a secondary (speculative) market develops. The selection of eligible households requires a targeting mechanism similar to that used for direct cash transfers. When well implemented, smart cards have proven to be an effective means of transferring targeted subsidies. (ESMAP/World Bank, 2008).

119. Lifeline tariffs - special low rates for small users - can be a cost-effective way of making services affordable to poor households (Komives et al., 2007). The premise of lifeline tariffs is that household energy use is highly correlated with income and thus a degree of selftargeting is possible. Richer households use electricity rather than other fuels for lighting, and may use a significant amount of electricity for air conditioning. The effectiveness and incidence of lifeline tariffs are, however, dependent on the targeted population being connected to the electricity or gas-distribution network and on the utility being able to measure each household's consumption. 
Because there is often an installation fee for a meter, poorer households are less likely to have meters than non-poor households, and thus to be excluded (World Bank, 2008). Where high upfront connection charges prevent poor people from gaining access to electricity, governments can finance part of the connection charge or oblige utilities to spread the cost out over time.

120. Independent of the choice of policy tool, targeting of benefits is crucial. Leakages to the non-poor can never be totally eliminated, but targeting minimizes such leakages and ensures that the poor are compensated for a reasonable portion of their losses. Even if an equal transfer to all households would be in most cases less regressive than universal subsidies, targeted transfers are usually the best support mechanism. A number of different targeting methods are available for directing resources to a particular group (Box 4.2). In practice, however, most programs do not use a single method, but a combination of methods.

\section{Box 4.2 Targeting Options to Address Individual Distributional Concerns}

1. Individual or Household assessment

- Means testing - eligibility is based on collection of information on households' income, wealth, or both. Ideally, the information is verified against independent data sources (administrative databases, official proofs of incomes, etc.) or through visits by social workers to verify the visible standards of living of the household.

o Proxy-means testing - eligibility is assessed through a score based on easy-to-observe household characteristics. The indicators used to calculate the score and their weight are based on statistical analysis of survey data. The information provided by the applicant is usually partially verified either by a program official through a home visit or by having the applicant bring written verification of the information.

○ Community based targeting - eligibility is determined by a group of community members or leaders, deemed to have good knowledge of each households' economic welfare.

2. Categorical targeting

$\circ$ Geographic targeting - eligibility is determined by location - people who live in the designated area are eligible and those who live elsewhere are not.

○ Demographic targeting - eligibility is determined based on demographic characteristics such as age.

○ Sector targeting - beneficiaries might include transport operators, farmers, and fishermen

3. Self-targeting - the selection mechanism is designed in such a way that take-up is expected to be much higher among the poor than the non-poor or the level of benefits is expected to be higher among the poor. One of the common applications of self-targeting is the subsidization of staple foods that are more heavily consumed by the poor than by non-poor. Quantity-based targeting in the case of electricity or gas tariffs can be considered also an application of this approach.

Source - Coady et al., 2004; Grosh et al., 2008; ESMAP, 2009

121. It should be recognized that each of these targeting options has costs. For example, means-testing requires information on the incomes and assets of the target population, which can be difficult in developing countries where the poor live in rural areas and accurate information is not available. While self-selection may appear to be a relatively costless way of identifying the poor, the presence of a large informal economy in many developing countries can discourage individuals from registering with the government.

122. In addition to the ability to identify beneficiaries, the government also requires the institutional facilities to monitor and enforce the conditions associated with the program. This will be a particular challenge for those developing countries where corruption is widespread. There must be a low-cost mechanism for transferring the payments to households, or the administrative costs could outweigh the benefits of targeting compensation.

123. Targeting schemes also carry less obvious costs that arise from incentive effects or behavioral responses. Incentive problems arise when a scheme encourages potential recipients of public spending to change their behavior to become eligible. For example, people may change their 
residence to qualify for a scheme that is geographically targeted. Schemes based on income can also encourage a "poverty trap", where there is no incentive to escape poverty. This has been a difficulty in Mexico, for example, where numerous studies have found that families leaving the Oportunidades programme after transitioning above the extreme poverty threshold have often been unable to escape poverty altogether due to the absence of an overall social protection system.

124. One innovative targeted subsidy approaches to support output-based aid (OBA) has been spearheaded by the Global Partnership on Output-Based Aid (GPOBA). This type of aid is conditional on the services first being provided to the poor. Unlike traditional forms of subsidy OBA subsidies are explicit in that they identify those who are receiving the benefits and for which specific reasons they are receiving it. Whereas traditional subsidy schemes are based on inputs, the OBA approaches are based on outputs against which the subsidies are disbursed making them more efficient in terms of results but also for identifying beneficiaries that need the subsidies the most.

125. OBA's approaches generally take the form of a one-off subsidy per household for part of the amount that is required to establish an initial connection and access to the electricity grid, natural gas heating, etc. GPOBA and the World Bank funded a scheme in Armenia providing grants to poor households for individual heating solutions based on gas heaters and in some cases boilers. Affordable and efficient heating is crucial for Armenia since winters there are harsh and low-income families allocate up to half of their total expenditures to heating during winter. The funds were disbursed only after the predetermined outputs were met, which provided an incentive for the utility providers to complete the installation in a timely and effective manner. A similar approach was used in Colombia, where 35000 new natural gas connections were made to poor households. Natural gas heating provides a cleaner, safer, and less expensive alternative to biomass for cooking and other uses. Connection fees were the highest fees for households so a one-off subsidy per household was sufficient to affect the quality and the welfare of each family. The beneficiaries were identified using an existing stratification rating system.

126. Other schemes may take the form of a transitional tariff subsidy, which is phased out as user contribution increases over time. A recent approach that utilized this mechanism is the rural electrification project in Ethiopia. Ethiopia is a country with one of the lowest electrification rates in Sub-Saharan Africa, where only an estimated 18 percent of the total nation's towns and villages have access to electricity and far fewer with metered connections. Most customers are not able to afford the connection to the nearest grid, which ranges from US\$ 50 to US\$100, equivalent to $15 \%$ of annual household income. Kerosene is the fuel used by $96 \%$ of households, despite it costing on average about $60 \%$ more than some consumers would pay for electricity to perform the same service. The main barrier is the initial connection. Working with the Ethiopian state-owned utility company, GPOBA designed and funded the performance-based subsidy according to which households would only pay about $20 \%$ of the connection fee after they acquired compact fluorescent lamps and metered connections, reducing the household bill by $55 \%$. 


\subsection{Lessons Learned}

127. The experiences of governments that have managed to successfully reduce fossil-fuel and electricity subsidies highlight some common features that point to strategies for other governments to consider. This final section summarizes the key insights gained from the discussion in this chapter and the more detailed description of case studies in Annex 3prepared by the OECD, OPEC and World Bank (see also UNEP, 2008 and ADB, 2009).

128. Increasing the availability and transparency of energy subsidies data is essential in overcoming some of the challenges related to reform. First, improved data on the scope and nature of fossil fuel subsidies can be useful in dispelling myths and misinformation about fossil fuel subsidies and can encourage informed discussion and debate among both those with an interest in maintaining the subsidies and those interested in their reform. In addition, subsidy data collection and transparency can promote peer review and encourage compliance with any future subsidy reform processes (Hale, 2008).

129. Providing financial support for economic restructuring or poverty alleviation can be essential to smoothing the path for reform of fossil-fuel subsidies. However, such support should be well-targeted, temporary, and transparent. It should not be automatically provided, but an assessment should be made of the extent to which the economy and society can absorb the impacts of the reform, especially if the reforms are phased in over a long period. Reforms to fossilfuel subsidies should also be considered in a package context, particularly if there are broader structural reforms underway or contemplated, and if there are opportunities to provide assistance for regional economic diversification. Pre-announcing a strategy and timeframe for phasing-in subsidy reform can help households and businesses to adjust to these reforms.

130. An important condition for successful subsidy reform is the credibility of the government's commitment to compensate vulnerable groups for energy price increases, and, more generally, to use the freed public funds in a beneficial way. Governments need to ensure public trust in the reform agenda through broad communication, and appropriate timing of subsidy removal and implementation of compensatory social policies. Groups that are severely affected by subsidy reforms - including but not restricted to the poor - need to be compensated. The compensation should be substantial enough to mitigate the adverse impacts that may occur, especially in the initial post reform period. A fine-tuned communication strategy is needed to explain the reform rationale and the associated compensatory measures that will be taken, before they are introduced, so as to establish trust in the reform program and to convince potential losers from reforms that the costs to them will not be as onerous as feared.

131. It is important to consider alternative policy tools to protect the poor, including cash and non-cash transfers, and lifeline rates, which generally perform better than universal subsidies. Cash transfers have many advantages over universal subsidies and other types of transfers, but may not be available or may be difficult to implement. Setting up the systems to implement a new program is indeed challenging but possible, as proved by the Indonesian case, but may require significant resources and a clear time frame. Compared with universal subsidies, targeted cash transfers tend to have lower leakage (inclusion errors) but sometimes higher exclusion errors if the programs are not well designed and implemented. The choice of program design features and institutional arrangements should be consistent with the administrative context and capacity in particular countries. Targeting of subsidies could also be improved by using available targeting instruments that can be supported with the use of administrative technological innovations, the use of social tariffs for gas and electricity, or income support for low-income households to help them pay their energy costs.

132. Since it may take time to put in place effective social safety nets, governments may want to consider the following options for assisting the transition of the poorer sections of the community, depending on the specific circumstances and challenges: 
- Temporarily maintain universal subsidies on those fuels that are better targeted to the poor and are more important in their budgets. Gasoline, diesel and LPG have generally proved to be poorly targeted. Kerosene subsidies can also be better targeted, if risks of adulteration with diesel for transport can be avoided or minimized.

- Introduce short term measures to alleviate the impact of tariff increases on the poor.

- Where poor households are connected to the grid and metering is in place, volume-differentiated tariffs are recommended. Volume-differentiated tariffs charge a lower price per unit for households whose total consumption is below a certain threshold and thus confine the subsidy to low-volume users.

$\circ$ Where poor households are not connected to the grid, connection-charge subsidies can be used. Within this context, technical assistance and grants, including OBA, can be deployed in the form of a one-off subsidy per household for part of the amount that is required to establish an initial connection and access to the electricity grid, natural gas heating, etc.

$\circ$ Where affordability is a major challenge, a transitional tariff subsidy may be used, which is then phased out as the user contribution increases over time. This is a performance-based subsidy under which households would only pay a percentage of the connection fee until after they acquired compact fluorescent lamps and metered connections, making the household bill more affordable in the short-term.

- Rationalize the fuel mix for electricity and transport, and encourage new consumption patterns by switching from traditional fuel to modern energy sources and discouraging private transport in favor of public transport (e.g., through subsidizing urban mass transport).

- Prioritize broader structural expenditures that can benefit the poor, including road and rural-electrification schemes, but also social expenditure (health, education).

\section{References and Background Papers}

Abouleinein, El-Laithy and Kheir-El-Din. 2009. "The impact of phasing out subsidies of petroleum energy products in Egypt", The Egyptian Center for Economic Studies.

Andriamihaja, N. and G. Vecchi. 2007. "An Evaluation of the Welfare Impact of Higher Energy

Prices in Madagascar." Africa Region Working Paper Series 106, World Bank, Washington, DC.

Asian Development Bank. 2009 Energy Policy, Asian Development Bank, June 2009.

Australian Government. 2007. "Cost Benefit Analysis Procedures Manual”, Nov. 2007, Version 1.0, Civil Aviation Safety Authority.

Bacon, Robert, Ley, Eduardo and Masami Kojima. 2010. "Subsidies in the Energy Sector: Measurement, Impact, and Design", Background Paper for the Energy Strategy, Washington, DC: World Bank.

Baig T., A. Mati, D. Coady and J. Ntamatungiro (2007), Domestic Petroleum Product Prices and Subsidies: Recent Developments and Reform Strategies, IMF Working Paper WP/07/71, Washington DC.

Berg, Holger, Andreas Burger and Karen Thiele, 2010. "Environmentally Harmful Subsidies in Germany", Federal Environment Agency, Dessau-Rosslau, Germany. 
Briceño-Garmendia, Cecilia, Karlis Smits and Vivien Foster. 2008. "Financing Public Infrastructure in Sub-Saharan Africa: Patterns and Emerging Issues." Africa Infrastructure Country Diagnostic, Background Paper 15, World Bank, Washington, DC.

Burniaux, Jean-Marc and Jean Chateau. 2010. "An Overview of the OECD ENV-Linkages Model", OECD Background Paper, OECD, Paris, available at www.oecd.org/g20/fossilfuelsubsidies

Canada Secretariat 1998. "Benefit-cost analysis guide", (July 1998), Treasury Board of Canada Secretariat, Ottawa.Berg, H., Burger, A., \& Thiele, K. (2008), Environmentally Harmful Subsidies in Germany Dessau, Dessau-Roßlau.

CdF (Charbonnages de France) (2006), Rapport d'activité 2005, Charbonnages de France, available at www.charbonnagesdefrance.fr/IMG/pdf/ra_activite_2005.pdf.

Charlotte de Fraiture et al, "Biofuels: implications for agricultural water use," International Water Management Institute, 2007.

Coady, David and David Newhouse, 2006. "Ghana: Evaluating the Fiscal and Social Costs of Increases in Domestic Fuel Prices". In Aline Coudouel, Anis Dani and Stefano Paternostro, eds., Poverty and Social Impact Analysis of Reforms. Washington, DC: World Bank.

Coady, David, Moataz El-Said, Robert Gillingham, Kangni Kpodar, Paolo Medas and David Newhouse, 2006. "The Magnitude and Distribution of Fuel Subsidies: Evidence from Bolivia, Ghana, Jordan, Mali, and Sri Lanka". Working Paper WP/06/247, International Monetary Fund, Washington, DC.

Coady, David, Robert Gillingham, Rolando Ossowski, John Piotrowski, Shamsuddin Tareq, and Justin Tyson, 2010, "Petroleum Product Subsidies: Costly, Inequitable, and Rising", IMF Staff Position Note No. SPN/10/05, 25 February 2010, International Monetary Fund, Washington, D.C.CONCAWE, EUCAR, EU-JRC. 2006. "Well-to-Wheels analysis of future automotive fuels and powertrains in the European context,", available at http://ies.jrc.ec.europa.eu/WTW

Dillon, Harbrinderjit Singh, Tara Laan and Harya Setyaka Dillon. 2008. "Biofuels: At What Cost? - Government support for ethanol and biodiesel in Indonesia", Global Subsidies Initiative of the International Institute for Sustainable Development, Geneva.

Europe Economics (2006), Evaluation of State aid for the Coal Industry, A report by Europe Economics and Fraunhofer ISI with BSR Sustainability and the Krakow Institute for Sustainable Energy for the European Commission DG for Energy and Transport, http://ec.europa.eu/energy/coal/studies/coal_en.htm

Ebinger, Jane, 2006. "Measuring Financial Performance in Infrastructure: An Application to Europe and Central Asia". Policy Research Working Paper 3992, World Bank, Washington, DC.

ESMAP, 2003a. "India: Access of the Poor to Clean Household Fuels". Report 263/03. Washington, DC: World Bank. www.esmap.org/filez/pubs/26303India.pdf.

ESMAP, 2003b. "Household Fuel Use and Fuel Switching in Guatemala". Technical Report. June 2003. Washington, DC: World Bank. www.esmap.org/filez/pubs/03603FueluseGuatemala.pdf.

ESMAP, 2003c. "Household Energy Use in Developing Countries: A Multicountry Study". Technical Report, October 2003. Washington, DC: World Bank. www.esmap.org/filez/pubs/HouseholdEnergyUseinDevelopingCountries.pdf.

ESMAP. 2004. Energy Policies and the Mexican Economy. Technical Paper 047, January 2004. Washington, DC: World Bank. 
Fattouh, Bassam. 2009., Fossil Fuel Subsidies: Issues, Impacts and Options for Reform, Oxford Institute for Energy Studies, University of Oxford.

French Senate (undated), Web-site of the French Senate, available at www.senat.fr/rap/104-074311/104-074-3115.html.

Global Subsidies Initiative, 2010 "Relative subsidies to energy sources: GSI estimates", http://www.globalsubsidies.org/files/assets/relative_energy_subsidies.pdf.

Global Subsidies Initiative, 2009. "Achieving the G-20 Call to Phase Out Subsidies to Fossil Fuels". Policy Brief, October, International Institute for Sustainable Development, Geneva.

Global Subsidies Initiative, 2008. "Biofuels: At What Cost? - Government support for ethanol and biodiesel in China", International Institute for Sustainable Development, Geneva.

Hale, T. N. (2008). "Transparency, accountability and global governance". Global Governance, 14

Hamid, Jalil (2008), Malaysia PM faces bigger protest, dissent over fuel, 12 June, Reuters.

IEA (International Energy Agency). 1988. Coal Prospects and Policies in IEA Countries. IEA, Paris.IEA. 2001., Coal information, 2000 edition, IEA/OECD, Paris.

IEA. 2002. Coal information, 2001 edition, IEA/OECD, Paris.

IEA 2007. Energy Policies of IEA Countries Germany 2007 Review, OECD/IEA, Paris.

IEA. 2008. Energy Policy Review of Indonesia, Paris: International Energy Agency. Paris.

IEA, 2008. "World Energy Outlook." Paris: International Energy Agency.

IEA, 2009a. "World Energy Outlook." Paris: International Energy Agency.

IEA 2009b. Energy Policies of IEA Countries Spain 2009 Review, OECD/IEA, Paris.

IEA 2009c. Energy Prices and Taxes: Quarterly Statistics, OECD Publishing.

IEA, 2010. "World Energy Outlook." Paris: International Energy Agency, Forthcoming.

IEEP et al. (2007), Reforming Environmentally Harmful Subsidies, Final report to the European Commission's Environment Directorate, March 2007, UK/Belgium.

Independent Evaluation Group (IEG). 2008. Climate Change and the World Bank Group. Phase 1-An Evaluation of World Bank Win-Win Energy Policy Reforms. Washington, DC: World Bank.

International Energy Forum (IEF), 2010. Assessment of Biofuels Potential and Limitations, IEF.

International Monetary Fund (IMF) 2007,.World Economic Outlook, "Globalization and Inequality," IMF, Washington, DC.

IMF, 2008. Food and Fuel Price Subsidies: Issues and Reform Options. A paper prepared by Fiscal Department, Washington, DC.

Ivanic, M. and W. Martin. 2008. "Implication of Reforming Energy Use in the Middle East and North Africa." World Bank, Washington DC.

Kelly, Elaine, 2009. "Pricing for Prosperity: Consumer Price Subsidies in MENA and the Prospects for Reform." University of London and Fiscal Studies, London, UK.

Kojima, Masami, Donald Mitchell, and William Ward. 2006. Considering Trade Policies for Liquid Biofuels. Washington, D.C.: World Bank.

Komives, Kristin, Vivien Foster, Jonathan Halpern, and Quentin Wodon. 2005. Water, Electricity and the Poor. Who Benefits from Utility Subsidies? Washington, DC: The World Bank. 
Komives, Kristin, Vivien Foster, Jonathan Halpern, Quentin Wodon, and Roohi Abdullah. 2007. Utility Subsidies as Social Transfers: An Empirical Evaluation of Targeting Performance. Development Policy Review 25 (6), 659-679.

Koplow, Doug, 2004. "Subsidies to Energy Industries". In Encyclopedia of Energy, Volume 5, ed. Cutler Cleveland. Amsterdam: Elsevier Inc.

Koplow, Doug. 2006. "Biofuels: At What Cost? - Government Support for Ethanol and Biodiesel in the United States", Global Subsidies Initiative of the International Institute for Sustainable Development, , Geneva:

Koplow, Doug. 2007. "Biofuels: At What Cost? - Government Support for Ethanol and Biodiesel in the United States - 2007 update", Global Subsidies Initiative of the International Institute for Sustainable Development, Geneva.

Koplow, Doug. 2009a. "Measuring energy subsidies using the price gap approach: what does it leave out?" Global Subsidies Initiative of the International Institute for Sustainable Development, Geneva: www.iisd.org/pdf/2009/bali_2_copenhagen_ff_subsidies_pricegap.pdf

Koplow, Doug. 2009b. A Boon to Bad Biofuels: Federal Tax Credits and Mandates Underwrite Environmental Damage at Taxpayer Expense, Earth Track and Friends of the Earth, Washington, DC.:

Kosmo, Mark, 1988. "Money to Burn? The High Costs of Energy Subsidies". Washington, DC: World Resources Institute.

Kpodar, Kangni. 2006. "Distributional Effects of Oil Price changes on Household Expenditures: Evidence from Mali." Working Paper WP/06/91, International Monetary Fund, Washington, DC.

Kutas, Géraldine, Carina Lindberg and Ronald Steenblik. 2007. "Biofuels: At What Cost? Government support for ethanol and biodiesel in the European Union", Global Subsidies Initiative of the International Institute for Sustainable Development, Geneva.

Laan, Tara, Todd Alexander Litman and Ronald Steenblik. 2009. "Biofuels: At What Cost? Government support for ethanol and biodiesel in Canada", Global Subsidies Initiative of the International Institute for Sustainable Development, Geneva.

Laan, Tara. 2010. "Gaining traction: transparency about fossil-fuel subsidies can accelerate reform". The Global Subsidies Initiative of the International Institute for Sustainable Development, Geneva, forthcoming 2010

Laan, Tara, Christopher Beaton and Bertille Presta. 2010. Strategies for Reforming Fossil-Fuel Subsidies: Practical lessons from Ghana, France and Senegal, Global Subsidies Initiative of the International Institute for Sustainable Development, Geneva, available at www.globalsubsidies.org/files/assets/strategies_ffs.pdf.

Larsen, Bjorn, and Anwar Shah. 1992. "World Fossil Fuel Subsidies and Global Carbon Emissions." Policy Research Working Papers, WPS 1002. World Bank, Washington, DC

Manzoor, Davood Asghar Shahmoradi, Iman Haqiqi. 2009 An analysis of Energy Price Reform: A CGE Approach, Imam Sadiq University and Ministry of Energy, Iran

Meyer, C. and D. Meyer. 2009. Environmentally Harmful Subsidies: How Perverse Financial Incentives Threaten Biodiversity, Study Commissioned by the Deutscher Naturschutzring (DNR), September Mitchell, Donald 2008. "A Note on Rising Food Prices," World Bank Policy Research Working Paper Series, No. 4682

Mody, Ashoka and Dilip Patro. 1996. Methods of Loan Guarantee Valuation and Accounting. World Bank Discussion Paper. The World Bank, Washington, DC. 
Morgan, Trevor (2007), Energy Subsidies: Their Magnitude, How they Affect Energy Investment and Greenhouse Gas Emissions, and Prospects for Reform, UNFCCC Financial and Technical Support Programme, Bonn.

Mullen, Kathleen, Dongsheng Sun, David Orden and Ashok Gulati. 2004. "Producer Support Estimates (PSEs) For Agriculture in Developing Countries: Measurement Issues and Illustrations from India and China." MTID Discussion Paper No. 74. International Food Policy Research Institute, Washington, D.C.

Oktaviani, R, Hakim, D.B, Siregar, Sahara. 2007. Impact of a Lower Subsidy on Indonesian Macroeconomic Performance, Agricultural Sector and Poverty Incidences: A Recursive Dynamic Computable General Equilibrium Analysis. MPIA Working Paper 2007-2008

OECD. 1987. National Policies and Agricultural Trade, OECD, Paris.

OECD, 1998. Improving the Environment through Reducing Subsidies (3 parts), OECD Publications, Paris.

OECD, 2003. Environmentally Harmful Subsidies: Policy Issues and Challenges, OECD Publications, Paris.

OECD, 2006a. Financial Support to Fisheries: Implications for Sustainable Development, OECD, Paris.

OECD, 2006b. Subsidy Reform and Sustainable Development: Economic, Environmental and Social Aspects, OECD Publications, Paris.

OECD, 2007. Subsidy Reform and Sustainable Development: Political Economy Aspects, OECD Publications, Paris.

OECD, 2008a. OECD Environmental Outlook, OECD, Paris.

OECD, 2008b. OECD, 2008b. Biofuel Support Policies: An Economic Analysis, OECD, Paris.

OECD, 2009a. Agricultural Policies in OECD Counties: Monitoring and Evaluation. OECD Publications, Paris.

OECD, 2009b. The Economics of Climate Change Mitigation: Policies and Options for Global Action Beyond 2012, OECD Publications, Paris.

OECD. 2010a. Interim Report of the Green Growth Strategy : Implementing our Commitment for a Sustainable Future. OECD, Paris

OECD. 2010b. OECD's producer Support Estimate and Related Indicators of Agricultural Support: Concepts, Calculations, Interpretation and Use (The PSE Manual). OECD, Paris.

OECD Secretariat. 2010. "Measuring Support to Energy - Version 1.0", OECD Background Paper, OECD, Paris, available at www.oecd.org/g20/fossilfuelsubsidies

OMB (Office of Management and Budget). 2010. "Budget of the U.S. Government, Fiscal Year 2011: Terminations, Reductions, and Savings." Washington, D.C.

Organization of the Petroleum Exporting Countries (OPEC). 2007. "World Oil Outlook 2007", OPEC, Vienna.

OPEC. 2008. "World Oil Outlook 2008”, OPEC, Vienna

OPEC. 2009. "World Oil Outlook 2009” OPEC, Vienna

OPEC Fund for International Development (OFID), 2009, "Biofuels and Food Security," 
Oskam, Arie J. and Gerrit Meester. 2006. "How useful is the PSE in determining agricultural support?”, Food Policy, Volume 31, Issue 2, April 2006, Pages 123-141.

Peters, G. 1988. "The interpretation and use of producer subsidy equivalents', Oxford Agrarian Studies, 17, 186-218.

REN 21; 2009. Renewables Global Status Report 2009 Update, http://www.ren21.net/pdf/RE_GSR_2009_Update.pdf

Saavalainen, Tapio and Joy ten Berge. 2006. "Quasi-Fiscal Deficits and Energy Conditionality in Selected CIS Countries". Working Paper WP/06/43, International Monetary Fund, Washington, DC.

Smith, Kirk R. and, Sumi Mehta. 2003). The burden of disease from indoor air pollution in developing countries: comparison of estimates, International Journal of Hygiene and Environmental Health, Vol. 206, Issue 4-5, 279-289

Sokana, Thomas. 2003, Country Study: Senegal.

Steenblik, Ronald, Christopher Beaton and Juan Simón. 2008. "Biofuels: At What Cost? Government support for ethanol and biodiesel in Switzerland: 2008 Update", Global Subsidies Initiative of the International Institute for Sustainable Development, Geneva.

Steenblik, Ronald. 2007. "Biofuels: At What Cost? - Government Support for Ethanol and Biodiesel in the Selected OECD Countries", Global Subsidies Initiative of the International Institute for Sustainable Development, Geneva.

Steenblik, R.P. and P. Coroyannakis, 1995. "Reform of coal policies in Western and Central Europe". Energy policy, vol. 23, no. 6, pp. 537-553.

Sterner, T. 2007. "Fuel Taxes: An Important Instrument for Climate Policy." Energy Policy 35: 3194-3202.

Storchmann, Karl , 2005. "The rise and fall of German hard coal subsidies Energy Policy". 33 1469-1492.

Suharmoko, Aditya. 2010. "Fitch ups RI ratings as economy strengthens", 26 January, The Jakarta Post.

Suwala . 2010., Lessons Learned from the Restructuring of Poland's Coal-Mining Industry, Global Subsidies Initiative (GSI) of the International Institute for Sustainable Development (IISD), Geneva, Switzerland.

United Nations Foundation (2003), Energy Subsidies: Lessons Learned in Assessing their Impact and Designing Policy Reforms, Geneva.

United Nations Environment Programme (UNEP) 2004. The Use of Economic Instruments in Environmental Policy: Opportunities and Challenges. Division of Technology, Industry and Economics. Paris.

UNEP 2003. Energy Subsidies: Lessons learned in assessing their impact and designing policy reforms, Division of Technology, Industry and Economics. Paris.

UNEP, 2008. Reforming Energy Subsidies, Division of Technology, Industry and Economics. Paris.

UN-Energy. 2007. "Sustainable Bioenergy: A Framework for Decision Makers," United Nations, New York, US.

US (EIA) 2008. "Federal Financial Interventions and Subsidies in Energy Markets 2007, Washington DC: US Department of Energy. 
Tangermann, Stefan. 2006. "Response to the article on 'How useful is the PSE in determining agricultural support?' by Arie Oskam and Gerrit Meester", Food Policy, Volume 31, Issue 2, pp. 142-147, DOI: 10.1016/j.foodpol.2005.10.008.

Vagliasindi, Maria. 2004. "The role of investment and regulatory reforms in the development of infrastructure across transition economies”, Utilities Policy, 12, 303-314.

Vagliasindi, Maria, and Ada Karina Izaguirre. 2007. "Private Participation in Infrastructure in Europe and Central Asia: A Look at Recent Trends." Gridlines series, no. 26, PPIAF, Washington, DC.

Vagliasindi, Maria, and John Nellis. 2009. "Evaluating Africa's Experience with Institutional Reform for the Infrastructure Sectors." Working Paper 23, Africa Infrastructure Sector Diagnostic, World Bank, Washington, DC.

Victor, David, 2009. "Untold billions: Fossil-Fuel subsidies, their Impacts and the Path to Reform". The Global Subsidies Initiative of the International Institute for Sustainable Development, Geneva. www.globalsubsidies.org/en/research/political-economy

Wooders, Peter. 2009. "Greenhouse Gas Emission Impacts of Liberalizing Trade in Environmental Goods.” Manitoba: International Institute for Sustainable Development. p 14.

World Bank, 2006. "Indonesia: Making the New Indonesia Work for the Poor". Report 37349-ID. Washington, DC: The World Bank.

World Bank, 2008. "Reforming Energy Prices Subsidies and Reinforcing Social Protection. Some Design Issues". Report 43173-MNA. Washington, DC: The World Bank

World Bank. 2008. "Zambia: Elements of Effective Public Private Partnerships in Infrastructure." World Bank Policy Note.

World Bank. 2009. World Development Report, World Bank, Washington DC.

World Bank. 2010 "Phasing out energy subsidies: a decision tree and evidence from case studies", World Bank Background Paper, World Bank, Washington DC, forthcoming.

World Energy Council. 2001. "Pricing energy in developing countries", available online at http://www.regulationbodyofknowledge.org/documents/163.pdf 


\section{Annex 1: Case study on Global Biofuels (prepared by OPEC)}

The strong economic growth cycle from 2001-2008 led to a significant expansion in the global demand for petroleum products. It was also a period that saw an upward movement in the oil price, culminating in the market highs of mid-2008. The two trends led to some investors looking to develop and grow the market for petroleum substitutes, with many viewing biofuels as the product with the greatest potential substitute for oil in the transportation sector. In some countries, biofuels were also seen as a means to reduce oil imports. In addition, the past decade also witnessed growing climate change concerns, with biofuels initially viewed as one of the key options for reducing greenhouse gas emissions. This combination of energy and environmental policies provided significant impetus to the biofuels industry.

In the period 2000-2008, total world production of the two main liquid biofuels - ethanol and biodiesel - expanded at an average growth rate of 20 per cent per annum to reach a volume of almost $1.4 \mathrm{mb} / \mathrm{d}$ in 2008. World ethanol production almost quadrupled over this timeframe, and biodiesel increased from virtually zero to about $230,000 \mathrm{~b} / \mathrm{d}$.

Figure 1 - Global biofuels production, 2000-2008

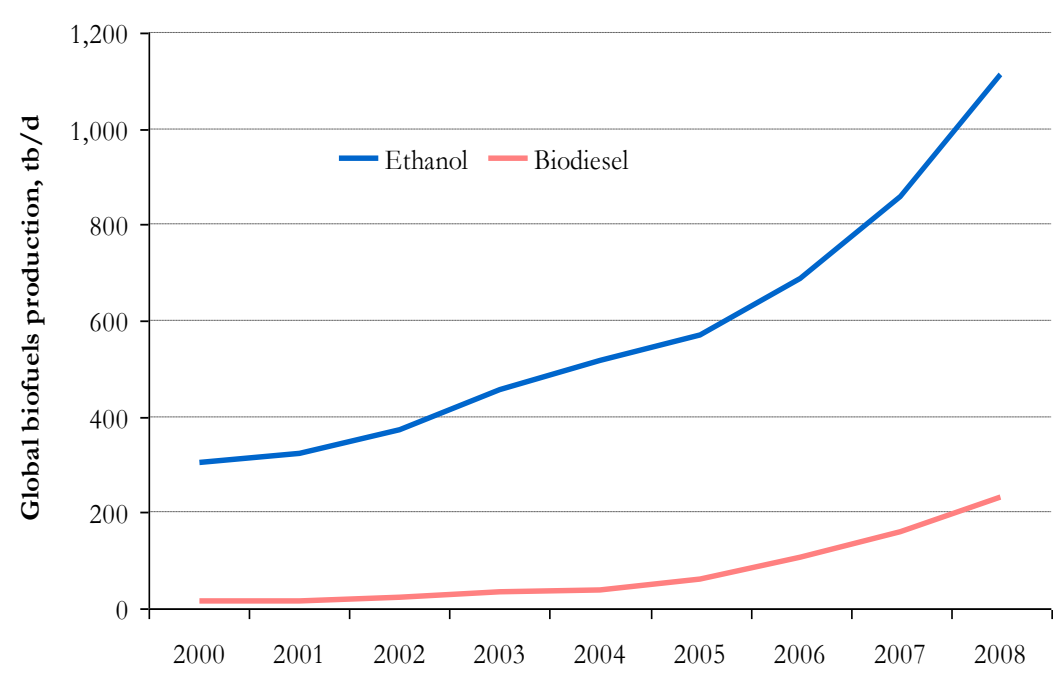

Source: OPEC Secretariat, 2009

It has been evident, however, that policy support has been required to ensure their development and use, as biofuels production costs often exceed the market value of the fuels. At different levels of jurisdiction - national, regional and local - biofuels subsidies were legislated in various forms:

- Exemptions or reductions in fuel-excise taxes;

- Tax credits to producers or blenders;

- Grants and soft loans for infrastructure;

- Payments to feedstock (crops) growers; and

- Import tariffs to protect domestic production.

The notable exception is Brazil, which is today seen as the least-cost, most efficient ethanol producer. In Brazil, government support is no longer provided to ethanol. 
According to the Global Subsidies Initiative (GSI) ${ }^{19,20}$, the United States (US) provided the most support in the OECD region, followed by the European Union (EU). Total support in the US and the EU in 2006 was US\$7.7 billion and \$3.7 billion respectively. Although government support is provided at all stages of production and consumption, the majority of subsidies are linked to production and consumption levels, so support is expected to rise in proportion to growth in the biofuels sector. The annual sum of biofuels subsidies is estimated to have risen in 2008 to around $\$ 13$ billion in the US, and to about $\$ 7$ billion in the EU. If policies remain unchanged, total US biofuels subsidy is projected to reach almost $\$ 16$ billion by 2014. Total US spending from 20062014 is estimated to be in the range of $\$ 105-110$ billion. ${ }^{21}$

It should also be noted that some governments, realizing that such high levels of subsidies constitute a large burden on the public treasury, have resorted to mandating specific levels of biofuels use (see Table 1). This shifts the burden directly to consumers.

Table 1 - Biofuels mandates in selected countries

\begin{tabular}{lll}
\hline Country & Mandate & Time frame \\
\hline Argentina & E5 and B5 & by 2010 \\
\hline Bolivia & B2.5 & by 2007 \\
& B20 & by 2015 \\
\hline Brazil & E22 to E25 & on going \\
& B3 & by 2008 \\
& B5 & by 2013 \\
\hline Canada & E5 & by 2010 \\
& B2 & by 2012 \\
\hline China & E10 & on going \\
\hline Colombia & E10 and B10 & on going \\
\hline Germany & E5.25 and B5.25 & in 2009 \\
& E6.25 and B6.26 & 2010 through 2014 \\
\hline India & E5 & by 2008 \\
& E20 & by 2018 \\
\hline US & 36 billion gallons & by 2022 \\
\hline
\end{tabular}

Adapted from 'Renewables Energy Global Status Report - 2009 Update,'

Renewable Energy Policy Network for the 21st Century, 2009

In the EU, some Member States have adopted mandatory blending requirements. In most of these cases, the blending ratios are set to increase progressively over time so as to attain, or exceed, the

\footnotetext{
${ }^{19}$ Biofuels - At What Cost? Government support for ethanol and biodiesel in the United States - 2007 Update (October 2007), http://www.globalsubsidies.org/files/assets/Brochure - US Update.pdf

${ }^{20}$ Biofuels - At What Cost? Government support for ethanol and biodiesel in the European Union (October 2007), http://www.globalsubsidies.org/files/assets/Subsidies to biofuels in the EU final.pdf

${ }^{21}$ OPEC calculations, based on data from References (1) and (4)
} 
target set by the European Commission (Directive EC 2003/30), of 5.75 per cent for biofuels in the transportation fuel market by 2010 . These mandatory blending requirements provide significant support to the biofuels industry. Furthermore, the EU adopted an objective of reaching a minimum 10 per cent biofuels share in the EU's overall transport petrol and diesel consumption by 2020 .

In the US, the Energy Independence and Security Act (EISA) of 2007 mandated the minimum supply of 36 billion gallons $(2.3 \mathrm{mb} / \mathrm{d})$ of renewable and alternative fuels by 2022, 15 billion gallons of which is expected to come from corn ethanol. Most of the remaining 21 billion gallons would come from cellulosic ethanol. Domestic politics in large consuming countries play a major role in pushing for expanded biofuels use. Often, three drivers are cited when public-sector support for biofuels is called for. These are: supply security, climate change and local development. However, what needs to be recognized is that these potential benefits are very much country- or region-specific.

In individual countries, first-generation biofuels based on domestic feedstock can only marginally enhance energy security. For example, corn-based ethanol is estimated to have a maximum production potential of close to $1 \mathrm{mb} / \mathrm{d}$ in the US, roughly equivalent to 10 per cent of the current motor gasoline consumption. Increasing corn-ethanol production to this amount, however, will require using roughly half the total US cropland currently planted with corn.

The environmental benefits of biofuels depend greatly on where they are produced and what feedstock is used. In Brazil, where conditions are favourable for growing the feedstock (sugarcane) and where production processes have had the opportunity to mature over a longer period of time than in any other country, ethanol production is estimated to reduce greenhouse gas emissions by 80-90 per cent, compared with gasoline. Ethanol produced from wheat in Europe could either increase emissions by 25 per cent, or decrease them by 65 per cent, depending on whether lignite or wheat straw is used as a heat source in the production process. ${ }^{5}$ Elsewhere, in the US, corn ethanol production is, at best, in the range of $10-30$ per cent ${ }^{22}$. According to the $\mathrm{GSI}^{1}$, in the US, the minimum possible subsidy cost per tonne of $\mathrm{CO}_{2}$ equivalent avoided is estimated at $\$ 295$ for corn ethanol, \$239 for biodiesel and \$109 for a hypothetical cellulosic ethanol case.

The most crucial subject in the debate over the sustainability of biofuels is the impact on the food supply of the large-scale use and trade of biomass for energy purposes. The ambitious biofuels targets initially contributed to extremely optimistic assessments for biofuels profitability. This in turn led to more crops being used as feedstock in biofuels production. Many believe that the expansion of biofuels did contribute to competition with food supplies and to high food prices, which were on an upward spiral by 2007. Others believe, however, some of the rapid rise in food prices could also be partly explained by rising energy costs, escalating fertilizer costs, underlain by expanding world incomes and increasing food demand. ${ }^{23}$

\section{References:}

Charlotte de Fraiture et al, "Biofuels: implications for agricultural water use," International Water Management Institute, 2007

\footnotetext{
${ }^{22}$ CONCAWE, EUCAR, EU-JRC, 2006

23 A Note on Rising Food Prices. World Bank Policy Research Working Paper Series, 2008, Donald Mitchell (July, 2008).
} 
CONCAWE, EUCAR, EU-JRC, "Well-to-Wheels analysis of future automotive fuels and powertrains in the European context," 2006

Donald Mitchell, “A Note on Rising Food Prices," World Bank Policy Research Working Paper Series, July 2008

Global Subsidies Initiative, "Biofuels - At What Cost? Government support for ethanol and biodiesel in the United States - 2007 Update," October 2007

IEF, “Assessment of Biofuels Potential and Limitations," A Report commissioned by the IEF, February 2010.

IMF, World Economic Outlook, “Globalization and Inequality,” October 2007

OPEC Fund for International Development (OFID), 2009, "Biofuels and Food Security,"

OPEC, “World Oil Outlook 2007”, OPEC, Vienna

OPEC, "World Oil Outlook 2008" OPEC, Vienna

OPEC, "World Oil Outlook 2009" OPEC, Vienna

UN-Energy, "Sustainable Bioenergy: A Framework for Decision Makers," United Nations, 2007 
Annex 2: Subsidies on electricity, LPG \& kerosene in countries with low levels of modern energy access (prepared by the IEA)

\begin{tabular}{|c|c|c|c|c|c|c|c|c|}
\hline \multirow[b]{2}{*}{ Country $^{1}$} & \multicolumn{4}{|c|}{ Poverty indicators } & \multicolumn{3}{|c|}{ Presence of subsidies ${ }^{2}$} & \multirow{2}{*}{$\begin{array}{l}\text { Electricity, LPG \& } \\
\text { kerosene subsidies as } \\
\text { a share of total } \\
\text { subsidies }\end{array}$} \\
\hline & Electrification rate & $\begin{array}{c}\text { Population } \\
\text { without } \\
\text { electricity }\end{array}$ & $\begin{array}{l}\text { Modern } \\
\text { fuels access }\end{array}$ & $\begin{array}{c}\text { Reliance on } \\
\text { biomass for } \\
\text { cooking }\end{array}$ & Electricity & LPG & Kerosene & \\
\hline & $\%$ & million & $\%$ & $\%$ & & & & $\%$ \\
\hline South Africa & 75 & 12 & 83 & 17 & yes & yes & no & 16 \\
\hline China & 99 & 8 & 42 & 58 & yes & yes & no & 38 \\
\hline Indonesia & 65 & 81 & 46 & 54 & yes & yes & yes & 58 \\
\hline Philippines & 86 & 13 & 49 & 51 & no & yes & no & 94 \\
\hline Thailand & 99 & 0 & 63 & 37 & yes & yes & no & 47 \\
\hline Vietnam & 89 & 9 & 34 & 66 & yes & no & no & 39 \\
\hline Bangladesh & 41 & 95 & 9 & 91 & yes & no & yes & 29 \\
\hline India & 65 & 405 & 29 & 71 & yes & yes & yes & 50 \\
\hline Pakistan & 58 & 70 & 32 & 68 & yes & yes & yes & 18 \\
\hline Sri Lanka & 77 & 5 & 20 & 81 & yes & yes & no & 23 \\
\hline $\begin{array}{l}\text { Peru } \\
\text { Other countries in IEA }\end{array}$ & 77 & 7 & 61 & 39 & no & yes & yes & 30 \\
\hline dataset & 48 & 95 & 32 & 68 & yes & yes & yes & 36 \\
\hline \multicolumn{8}{|c|}{ Value of subsidies on electricity, LPG and kerosene in above countries as a share of global fossil fuel consumption subsidies in 2008} & 11 \\
\hline
\end{tabular}

Notes

1. Countries have been selected from the IEA subsidies dataset on the basis of their low levels of modern energy access (ie. electrification rate lower than $95 \%$ or modern fuels access lower than $85 \%$ )

2. Kerosene, LPG and electricity have been selected as they support the basic needs of the poor and can be more easily targeted than subsidies on other energy forms.

3. Currently 1.5 billion people - or $22 \%$ of the world's population - lack access to electricity and 2.5 billion people rely on biomass as their primary fuel for cooking. Sources: IEA (2009a), IEA (2010) 


\section{Annex 3 - Selected case studies of subsidy reform in OECD and non- OECD countries (prepared by the OECD)}

This Annex provides details of selected case studies of fossil-fuel subsidy reform in selected OECD and non-OECD countries. They have been drawn from existing literature and represent subsidy reforms in both consumer and producer sectors. Depending on the information available, each case study focuses on identifying: the type of subsidy and the proposed reform; the drivers of subsidy reform; the results and key factors affecting the outcome; and key lessons from the subsidy reform

\section{Case Studies of Consumer Subsidy Reforms}

Reform of Poland's reduced VAT for energy products

Type of subsidy and proposed reform

The VAT rate for energy products (7\%) was less than one third of the basic national VAT rate (22\%) in Poland in the early 1990s. The reform proposed to gradually increase the VAT for energy products to bring it into line with the basic rate of VAT. This was planned to be carried out over three years from an initial base of $7 \%$ in 1995 , to $12 \%$ in 1996, $17 \%$ in 1997, and finally up to $22 \%$ in 1998.

\section{Drivers of subsidy reform}

The reform was carried out for economic and budgetary reasons, to increase revenue to the budget. The reform was reinforced by external actors, e.g. international financial institutions such as the IMF and the World Bank.

\section{Results and key factors affecting the outcome}

The VAT increase from 1995 to 1998 was successful and took place as scheduled. However, a previous proposal that would have seen VAT on electricity increase to 22\% in 1995 was dropped at the end of 1994 as part of a package of measures to curb inflation.

Protests and strikes against higher energy prices and consumer price increases in general were widespread in Poland during the 1990s. Trade unions did not object to the raises in VAT, but sought compensation for energy price increases. The Polish government assured unions that excessive price hikes would not be allowed. Compensatory measures were taken for poor families and pensioners that were hit hardest by the higher energy prices. These measures included direct allowances as well as cheap credit to finance the modernisation of local heating sources. The amounts budgeted for direct compensation payments were generally modest and pertained only to $1 \%$ of all households.

A favourable circumstance creating the policy space for the reform was that the fact that inflation in Poland was falling continuously from 586\% in 1990 to $7 \%$ in 1999, while real disposable household income was increasing rapidly. As a result, the share of expenditure on energy in household consumption did not increase significantly over the 1990s despite the real 
energy price increases. The share amounted to $6.7 \%$ in $1991,9.5 \%$ in 1993, and was estimated at $7.2 \%$ in 2005 .

\section{Key lessons from the subsidy reform}

Market fluctuations and the relaxation of price controls were more important determinants of consumer prices for energy than an increasing VAT rate in Poland during the 1990s. This is a key lesson for a number of other EC Member States which still have reduced VAT rates for energy products. This case study shows that increasing VAT rates for energy products to basic VAT rates can be achieved relatively expediently with a limited need for compensatory payments, even in a country where, at the time, household income was much lower than in most EU Member States. However this of course should be tempered with the economic background of falling inflation rates and growing household incomes.

\section{Reform of direct subsidies for petroleum products in Indonesia}

\section{Type of subsidy and proposed reform}

The Government of Indonesia provided direct subsidies to keep the price of petroleum products low. It is estimated that the fuel subsidy provided by the Indonesian government was $3.4 \%$ of GDP in 2005 and 2\% in 2006 (Baig et al., 2007). The reform involved the removal of subsidies to certain petroleum products in 2005 and the reduction of subsidies on other products over time. The fuels that continued to be subsidised were kerosene, automotive diesel oil (ADO) and 88 octane gasoline (IEA, 2008).

\section{Drivers of subsidy reform}

In May 2008 Indonesia's Finance Minister estimated that the combined subsidies for fuel and electricity would total around USD 20.5 billion in 2008, making up about $4.5 \%$ of GDP and $20 \%$ of total government spending, outstripping spending on housing, law and order, health and education combined (IEA, 2008; IEA, 2009b).

Despite the original purpose of the subsidies to support low income households, only a small amount of the subsidies to oil products reaches the poor (defined as the population living under USD 2 a day) in Indonesia, who represent 20\% of the population. The near poor (those living on between USD 2 - 3 per day) represent another $10 \%$ to $12 \%$ of the population, but together the poor and near poor consume only about 10 million barrels of kerosene out of about 65 million barrels consumed each year. About 20 million barrels were used in the non-household sector in 1998, and the remaining 35 million were consumed by middle and high-income households. In 1999, only about USD 260 million, or roughly 15\% of the total kerosene subsidy of about USD 1.75 billion reached the poorest $30 \%$ of the population. In aggregate terms then, removing subsidies would affect high-income households more than the poor. Experience in other countries has shown that the poor suffer more in relative terms since a greater proportion of their budget is spent on fuel and therefore some sort of safety net is essential when subsidies are removed. However, the cost of this safety net will generally be significantly less than the current cost of oil subsidies (United Nations Foundation, 2003).

\section{Results and key factors affecting the outcome}

In early 2005 the Energy and Mineral Resources Minister announced that the government will gradually liberalise the domestic fuel market from 2005 to 2010, with the aim of completely 
eliminating fuel subsidies by 2010 (IEA, 2008). Initial exceptions to this included kerosene for household use, automotive diesel oil (AD) and gasoline for transportation (IEA, 2008). In October 2005 , the government raised subsidised prices by an average of $125 \%$. However, as energy pricing is a Presidential decision, it was decided that further price increases in the subsidised fuels should be put on hold until after the Presidential election in 2009. The international crude oil increase of 2007-08 made this price fix untenable and the government increased subsidised fuel prices in May 2008 by an average of $28.7 \%$ (IEA, 2008; IEA, 2009c).

Alongside these price increases, the Government undertook a cash transfer programme to 16 million poor families, providing them with 300,000 rupiah (about EUR 23) every three months. The full annual cost of the programme is estimated at nearly $0.7 \%$ of GDP (Baig et al., 2007).

Initially, the subsidy on kerosene was not substantially reduced, and its price remained at twothirds of the world price. However, the kerosene subsidy has been reduced significantly subsequent to the implementation of the transfer programme in May 2008 (Baig et al., 2007). The subsequent price rises led to a short-term fall in demand for kerosene, however this did not last long and demand returned to normal levels (IEA, 2008). In addition, in December 2009 Indonesia awarded a contract to Petronas, the Malaysian oil and gas company to supply fuel in Indonesia, progressing the liberalisation of the petroleum products sector and providing competition to Pertamina, Indonesia's state-owned oil firm (Ali, 2009).

The Ministry of Energy and Mineral Resources (MEMR) is pursuing alternative means to reducing the subsidy by focusing on reducing the volumes of subsidised fuels sales and encouraging the establishment of a competitive market and fuel price competition in the market. The government instituted a programme to reduce the use of kerosene by replacing it with liquefied petroleum gas (LPG), which is non-subsidised. This programme relied on the free distribution of LPG bottles and stoves (approximately 4.03 million stoves were distributed for free in 2007) as an incentive for households to switch from kerosene to LPG (IEA, 2008).

\section{Key lessons from the subsidy reform}

The Indonesian experience highlighted the importance of ensuring a suitable compensation strategy for poorer sections of the community in implementing reform, and that this can be a reduced impact on government expenditures and as a proportion of GDP. At the same time, it was important to provide a stepped approach to the reform, with some fuels being tackled later in the reform process, and taking a comprehensive approach to the policy problem (for example, focussing on changing household behaviour with support to switch from kerosene to LPG).

\section{Reform of electricity price subsidy in Indonesia}

\section{Type of subsidy and proposed reform}

Indonesia has maintained an energy tariff that creates artificially low prices of electricity. It is estimated that the average revenue received by the state-owned electricity company, PT Perusahan Listrik Negara (PT PLN) is equivalent to about USD 0.06 per kilowatt hour, while the average cost of production is USD 0.12 per kilowatt hour. The difference between PT PLN costs and revenue is made up by the government. In 2005 this was IDR 10-15 trillion (USD 1.6 billion). The 2008 National Budget estimate for electricity subsidy was IDR 29.8 trillion (USD 3.2 billion) to account for a sharply increasing global oil price, but was revised upwards to IDR 60.3 trillion (USD 6.4 
billion) in early 2008 as petroleum prices continued to climb. A further subsidy is provided for the express purpose of increasing grid connections to the poor (IEA, 2009b; IEA, 2008).

In early April 2008, The Ministry of Energy and Mineral Resources (MEMR) announced that the government would cease paying subsidies from May 2008 to larger industrial electricity consumers. This was an area where the government is able to make subsidy reductions without causing direct economic hardship for Indonesia's poor. MEMR estimated that this subsidy cut could save the government up to USD 270 million annually (IEA, 2008).

\section{Drivers of subsidy reform}

Rapid economic expansion and extensions to Indonesia's electricity grid between 1990 and 1997 led to a growth in electricity consumption at an annual average rate of $13 \%$. Investment in new generation capacity kept pace with the growth in demand until 1997, when the Asian Financial Crisis of 1997/98 had a profound impact on the Indonesian economy, leading to a fourfold depreciation of the Indonesian Rupiah against the US dollar and the sharp decline of economic activity. The growth in electricity demand slowed briefly but recovered quickly, reflecting the strong underlying demand. Electricity consumption grew at an average annual growth rate of $7 \%$ between 1997 and 2005. Indonesia depends heavily on oil for electricity generation, and in 2004 moved from a net exporter of oil to a net importer. The MEMR has forecast Indonesia's electricity demand to triple over the next two decades, equivalent to an average annual increase of $7 \%$ (IEA, 2008; IEA, 2009b).

The depreciation of the Rupiah and the subsequent higher costs that the state-owned electricity company, PT Perusahan Listrik Negara (PT PLN) faced, was only partially accounted for by the Government when adjusting the maximum retail price of electricity by PT PLN (IEA, 2008; IEA, 2009b). However, while the Indonesian government appreciated the need to make adjustments to the electricity tariffs, large one-off adjustments made in the past were strongly opposed at the community level and triggered violent public demonstrations (IEA, 2008).

Negative cash flows prevented PT PLN from undertaking much needed investment in the electricity sector; not only in installing new generation capacity but also normal repair and maintenance schedules. This has contributed to the increasing frequency of significant power supply disruptions due to the breakdown of generation plants and the transmission and distribution systems. Consequently, the rate at which PT PLN has added new customers to the grid has slowed considerably since the Asian economic crisis in 1997/98 (IEA, 2008). ${ }^{24}$

The distributional impact of the subsidy was also a key driver of the reform. In May 2008, the Co-ordinating Ministry of Economic Affairs of Indonesia advised that the top $40 \%$ of high income families benefit from $70 \%$ of the subsidies while the bottom $40 \%$ of low income families benefit from only $15 \%$ of the subsidies. In essence, the subsidies are benefitting the rich more than the poor (IEA, 2008). The relatively widespread acceptance of subsidy reductions in October 2005 and May 2008 highlighted the growing awareness of Indonesian communities of the need for some level of reform (IEA, 2008).

24. The Indonesian Government has set an ambitious electrification target of 93\% and PT PLN its own target of $100 \%$ of the population connected to the grid by 2020 (IEA, 2008). 


\section{Results and key factors affecting the outcome}

In August 1998, the government outlined key proposed reforms in the electricity industry. The intended reforms included industry restructuring, introducing competition and introducing a tariff regime based on full cost recovery. These reforms were introduced under a new Electricity Law in 2002. However, this was annulled by the Constitutional Court in December 2004. The provisions for a competitive electricity market and unbundling of PT PLN were ruled as unconstitutional by the court (IEA, 2008).

The removal of electricity subsidies to larger industrial electricity consumers has been implemented successfully (IEA, 2008). The price of electricity for other industry and households have not seen an increase since 2003 and remains at USD 0.07 per $\mathrm{kWh}$. A 20-30\% increase in price was planned for January 2010; however the increase has been postponed as the government continued to study the impact on the budget deficit (Suharmoko, 2010).

\section{Reform of price caps on prices of electricity and petroleum products in Malaysia}

\section{Type of subsidy and proposed reform}

Malaysia has had a cap on the price of electricity and petroleum products in place for some years. The difference between world market prices and the caps have been subsidised by the government.

In 2008 the government introduced a broad package of reforms to their energy subsidies, which were creating a mounting fiscal burden. The package included subsidy reductions, cash rebates, windfall taxation on certain sectors and an expansion of the social safety net (IEA, 2009c).

In August 2008 the price of natural gas for power generation was raised by $124 \%$ in Peninsular Malaysia, and the average electricity tariff for all sectors of the economy was increased by $24 \%$ (from USD $0.075 / \mathrm{kWh}$ to USD $0.093 / \mathrm{kWh}$ ) in line with the increase in its gas price (IEA, 2009c). Malaysia increased petrol prices by $41 \%$ and diesel prices by $63 \%$ in June 2008 (IEA, 2009c; Hamid, 2008). To offset the increased prices, the Malaysian government offered cash rebates in the form of lower annual road taxes (The Star, 2008).

\section{Drivers of subsidy reform}

Rising oil prices in 2007 and 2008 substantially increased subsidies as the gap between world market prices and the price caps on electricity and petroleum products widened, putting pressure on the Budget and prompting the Malaysian government to review their subsidy policies. Subsidies were reported to have cost the Malaysian government USD 14 billion in 2008, or about $4 \%$ of GDP (IEA, 2009c).

\section{Results and key factors affecting the outcome}

The price rises were successfully implemented despite widespread protests (IEA, 2009c; Hamid, 2008). 


\section{Reform of consumer price subsidy for natural gas in the United States}

\section{Type of subsidy and type of reform}

Prices of natural gas transported across state lines were regulated in the United States from the mid-1950s through to 1978, resulting in a consumer subsidy for natural gas through price regulation. In 1954, the U.S. Supreme Court ruled that natural gas producers that sold natural gas into interstate pipelines were subject to regulatory oversight by the Federal Power Commission (FPC). The decision had a far-reaching effect on the natural gas industry. In regulating well-head prices, the FPC instituted a rate-making determination based on the cost of providing the service, rather than the market value of that service. Prices were set to allow companies to charge prices high enough to cover the actual costs of producing natural gas, plus a 'fair' profit.

In 1978, the government decided to end the subsidy through the de-regulation of federal government price controls on natural gas sold in interstate markets.

\section{Drivers of subsidy reform}

Regulating prices charged by the large number of different natural gas producers created an extreme administrative burden for the FPC. Prices were kept artificially low for the next 20 years, fueling a large increase in consumption. However, producers had little incentive to explore for and develop new natural gas supplies at the regulated price. And, eventually, as oil prices started to rise in the 1970s, less and less natural gas was exported from the producing states and more was kept in-state, where prices were not regulated. In 1965, one-third of the United States' proved reserves were earmarked for intrastate consumers; by 1975 , the share had increased to almost $50 \%{ }^{25}$ Wellhead price control eventually culminated in the natural-gas shortages, beginning in the 1970s.

In response, the federal regulators established a curtailment schedule, placing interruptible consumers (i.e., those with the capability to use another fuel) at the bottom of the list. After the oil price shocks of the mid-1970s, natural gas for power generators and heavy industrial consumers outside of the producing states became scarce, and electricity prices doubled or even trebled. In winters of 1976 and 1977, shortages of natural gas forced the closing of many schools and factories in the U.S. Midwest.

\section{Results and key factors affecting the outcome}

In response, the U.S. Congress enacted the Natural Gas Policy Act (NGPA) in November 1978, at the peak of the natural gas supply shortages. Although the NGPA did not immediately deregulate prices, it started the process. However, it required passage of the Natural Gas Wellhead Decontrol Act (NGWDA) in 1989 to complete the process of deregulation. As of 1 January 1993, all remaining regulations applying to the well-head price of natural gas were eliminated, allowing the market to completely determine the price of natural gas at the wellhead. Well-head price deregulation had two major effects: it spurred production, and it encouraged a more rational use of natural gas. Whereas in the 1960s large industrial and power-plant facilities using natural gas burned it in rather simple steam generators, higher prices (combined with developments in technology) spurred the replacement of these inefficient technologies with combined-heat and power and combined-cycle gas turbines. 
Consumers accepted the inevitability of higher gas prices after petroleum prices had also risen dramatically in the mid-1970s.

\section{Key lessons from the subsidy reform}

The effects of price regulation were foreseen by economists before the shortfalls in deliveries started to become acute, but it took a crisis to spur policy makers into action. The process of deregulation took many years. But once it was completed, new domestic supplies became available, in response to higher prices.

\section{Case Studies of Producer Subsidy Reform}

\section{Reform of partial exemptions from ecotaxes in Germany}

\section{Type of subsidy and proposed reform}

When the ecotax (fuel excise duties and electricity tax) was implemented in 1999, it contained partial exemptions for enterprises in the manufacturing sector and in agriculture and forestry. The exemptions allowed qualifying businesses to pay only $20 \%$ of the standard rate and also provided a peak equalisation scheme, guaranteeing enterprises in the manufacturing sector a refund of $95 \%$ of the remaining eco tax payments that exceed the relief on pension scheme contributions. (IEEP et al., 2007). ${ }^{26}$

The proposed reform reduced the ecotax exemptions (i.e. raising the amount of ecotax the affected businesses pay) with the result that affected businesses will pay more of the ecotax (IEEP et al., 2007).

\section{Drivers of subsidy reform}

The drivers for this reform were both environmental and political. Environmental groups, including Germany's Green Party and environmental NGOs, were major promoters of reform for environmental reasons. The European Commission was a main promoter of reform on competition grounds because ecotax exemptions potentially distort competition. The Commission allowed reduced industry ecotax rates to be continued until 2012, but approved the tax cap only under the condition that the German industry meets its voluntary commitment targets. These targets were committed to by industry in order to obtain ecotax exemptions and involve the mandatory reduction of 20 million tonnes of $\mathrm{CO}_{2}$ emissions (IEEP et al., 2007).

\section{Results and key factors affecting the outcome}

The reform was carried out successfully in 2003, with the reduced ecotax rates for businesses increased from $20 \%$ to $60 \%$ of the full rate and the tax-cap provision modified upwards. However, this seems to have been a temporary success, as the reform has faced a setback in 2006, with new exemptions having been created with the 2006 Energy Taxation Law, including total exemptions of certain energy-intensive processes from energy taxation. In addition the reduced ecotax rates have applied to the entire energy tax rates for heating fuels, i.e. including the petroleum excise duty that already existed before 1999. For electricity (which before 1999 was not taxed at all) and for

26. Ecotaxes are the taxing of environmental 'bads' as opposed to taxing conventional goods or labour. Ecological tax reform (ETR) was designed as a revenue-neutral reform that simultaneously increased energy taxes and lowered payroll taxes (IEEP et al., 2007). 
natural gas and liquefied gas, this continues to mean a reduction of $40 \%$; for heating oil - owing to the objections by the European Commission - it means a reduction of $26.7 \%$. But because of the broadening of the calculation base to include all standard tax rates, both the tax burden and tax revenue are falling. Furthermore at the end of June 2007 the peak equalisation scheme was renewed virtually unchanged until 2012 with retroactive effect from the beginning of 2007.

The short period from the introduction of the ecotax to the reform ( 3 years) provides an insufficient time span and data to tell what the impact of reform is on energy use. The change of the tax rates by the reform for enterprises in the manufacturing sector was not very great (e.g. for electricity and natural gas below ten percent of the consumer prices). Moreover this small difference was absorbed for many enterprises in the manufacturing sector by the peak equalisation scheme. Therefore the reform could not affect the energy prices of these enterprises in a strong way. Other factors, especially the changes of the crude oil price, could change the energy prices even more significantly. This is why the results of the reform cannot be really estimated.

Concerns about competitiveness in the world markets continue to be a popular argument against applying ecotaxes on industry and increased energy prices contribute to the perception that there is already a heavy burden on industry (IEEP et al., 2007).

\section{Key lessons from the subsidy reform}

Ecotax reform is politically difficult to defend to the public and stakeholders. Worldwide differences in energy taxation provided the rationale for granting ecotax exemptions to domestic industries and contribute to the difficulties in reforming the ecotax (IEEP et al., 2007). A key outcome of the reform, however, was the chance of moving towards a harmonised energy taxation with a harmonised reduction of subsidies.

\section{Reform of subsidies to hard coal mining in Germany}

\section{Type of subsidy and proposed reform}

Direct subsidies from the German Federal Government and the Federal State of North RhineWestphalia to cover the difference between the production cost and the world market price of coal exports, and to provide social adjustment support related to the closure of mines (IEEP et al., 2007).

The reform aims for a gradual reduction of the subsidies to a complete removal of subsidies by 2018. This is achieved by reducing the subsidies from EUR 4.73 billion to EUR 2.71 billion between 1998 to 2005, reducing further to EUR 2.5 billion in 2006 and EUR 2.38 billion in 2008, with a complete phase-out of coal production by 2018. A review of the reform is planned to take place in 2012 (IEEP et al., 2007).

\section{Drivers of subsidy reform}

In Germany, hard coal mining has been subsidies for almost half a century (Frondel et al, 2007). The original subsidies were provided by a surcharge on the price of electricity, i.e. the socalled 'Kohle-Pfennig' (coal penny). This was considered unconstitutional by the German Constitutional Court in 1994 and required the subsidy to be shifted to the budget. This shift of the source of subsidies from the German energy consumer to the budget led to domestic budgetary and environmental considerations becoming the main drivers of subsidy reform. European competition 
legislation and a new government in the federal state of North-Rhine Westphalia were other drivers of the reform (IEEP et al., 2007, IEA, 2007).

\section{Results and key factors affecting the outcome}

The subsidies have been reduced and this has led to a reduction in the number of operating mines (from 19 to 8), with three additional closures envisaged before 2012. Coal production has declined from 53.1 million tons in 1995 to 24.7 million tons in 2005 (IEEP et al., 2007; Europe Economics et al., 2006). However, in 2006 the coal mining industry continued to be the biggest receiver of direct financial subsidy from the German government with EUR 1.7 billion in grants (Berg et al., 2008).

The share of hard coal in primary energy consumption has decreased slightly (from 14.1\% in 1997 to $12.7 \%$ in 2008), however not as quickly as the share of hard coal in primary energy production (from 34\% in 1997 to $12.6 \%$ in 2008), implying that domestic coal has mainly been replaced with imported coal to some extent (IEA, 2009). Nevertheless the primary energy consumption of hard coal has significantly decreased in these years, as well in absolute as in relative terms, and is still decreasing (a share of $11.1 \%$ of total primary energy consumption in 2009).

The number of employees in the hard coal mining industry declined from 92600 to 38500 between 1995 and 2005 while labour productivity increased slightly, from 574 tonnes to 641 tonnes per head per year (Europe Economics et al., 2006).

The average unemployment in the North Rhine Westphalia (11\%) is only slightly higher than the national average (10.5\%). However certain mining regions of North Rhine Westphalia such as the Ruhr region have relatively high rates (14\%). Within the Ruhr region in particular, Gelsenkirchen and Duisburg have relatively high unemployment rates (23\% and 16\% respectively) (Europe Economics et al., 2006).

The decline in coal production is part of a long-term development caused by other factors which in general has led to the deterioration of economic conditions for German coal mining in relation to international competitors, even with the heavy subsidisation enjoyed by the coal mining sector prior to the beginning of the reform in 1997 (IEEP et al., 2007).

Therefore there is a widespread public awareness that coal subsidies run counter to economic sense. However, subsidies are defended as a vehicle to maintain jobs and domestic energy supply. Other energy supplies in Germany's energy mix are natural gas, $80 \%$ of which is imported and nuclear energy, which is powered by uranium that is $100 \%$ imported (IEEP et al., 2007).

\section{Key lessons from the subsidy reform}

Shifts in political power open up new opportunities for subsidy reform and EU legislation and policies have played a critical role in helping to overcome domestic lock-in of coal subsidies in Germany. But even more importantly, growing public concern about the financial and environmental effects of the subsidies can support the process of reforms. 


\section{Reform of subsidies to hard coal mining in Poland}

\section{Type of subsidy and proposed reform}

Prior to 1990, the coal mining sector in Poland was state owned and was operated to provide high employment and cheap energy, rather than to generate profits. Local policies kept coal prices below international levels, with economic and environmental consequences. This was achieved through low end-user prices, market barriers, and direct subsidies to the state-owned enterprises (IEEP et al., 2007; Suwala, 2010).

The reform of the coal-mining industry in Poland led to the restructuring of the mining sector from centralised planning to separate independent enterprises. In 1990, centralised planning was abolished and 70 individual coal mines were established as independent enterprises with the right to market their output independently, both domestically and abroad.

\section{Drivers of subsidy reform}

Political and economic change in 1989 from Communism to a market economy allowed changes to the mining sector and the reform of government subsidies to the sector. A key objective of the government was to liberalise coal prices so that they could be determined by market forces (IEEP, 2007).

\section{Results and key factors affecting outcome}

The initial restructuring in the early 1990s failed due to stiff competition and falling prices, which threatened the financial viability of the enterprises (Suwala, 2010). Further restructuring then took place and the current system groups the remaining 54 mines into a number of stock companies that are owned or partly owned by the State, but are operating as independent enterprises. Three stock companies are wholly owned by the State: Kompania Węglowa S.A. (with 15 coal mines, it is the biggest steam coal producer in Europe); Jastrzębska Spółka Węglowa S.A. (which owns 6 coal mines and is the biggest cocking coal producer in Europe); and Katowicki Holding Węglowy S.A. (6 coal mines producing steam coal). Two further companies are partly owned by the State: Lubelski Węgiel „Bogdanka S.A. (which is a steam coal producer and was privatized in 2009 - 2010 with $4.5 \%$ shares being owned by the State); and Poludniowy Koncern Węglowy S.A. (which owns one coal mine and is 52\% owned by Poludniowy Koncern Energetyczny S.A., which in turn is part of the State-owned TAURON Polska Energia S.A.). ${ }^{27}$ A liquidation company, Spółka Restrukturyzacji Kopalń S.A., was to be established to take over mines that are to be closed. Finally, Węglokoks S.A. is a State-owned company that is Poland's biggest coal exporter.

Employment in the sector has fallen from 434,100 employees as at 1990 to 119,000 employees as at 2009. The impact of mine closures on unemployment rates seems to be diverse between regions in Poland, with the Silesa region, seen as the most important mining area in Poland, has been experiencing a constant reduction in unemployment between 2000 and 2006 and Katovice seeing an increase from $1.6 \%$ to $2.3 \%$ from the beginning to the end of 2005 (Europe Economics et al., 2006).

27. There is one private steam coal producer, KWK, „Siltech” Sp. z o.o. 
Restructuring of the industry continues and public funding will be dedicated to restructuring of employment and reducing production capacities (IEEP et al., 2007; Suwala, 2010). After the entry of Poland into the European Union, the State aid was granted in accordance with the Council Regulation (EC) No 1407/2002 of 23 July 2002 on State aid to the coal industry. In 2009 total value of aid granted to coal industry come to approximately PLN 360 million. More than $67 \%$ of this amount was given to Spółka Restrukturyzacji Kopalń S.A., the state owned company established as a liquidation company responsible for coal mines liquidation, managing of property of closed mines, and creation of new job for miners who lost their job as a result of the restructuring processes. Another $32 \%$ of the total value of state aid was given to pensioners from liquidated coal mines as a coal equivalent, paid by National Insurance Institution. Poland does not provide state aid to cover the current production losses.

The international price of hard coal has increased in recent years, improving the economic situation of some coal mines. This has raised questions about the rationale for maintenance of state support for profitable companies, and there is intense discussion on the efficiency of the sector. However, potential plans to withdraw financial support for selected mines face strong resistance from industry (IEEP et al., 2007).

\section{Key lessons from the subsidy reform}

Reforming heavily subsidised sectors can weigh heavily on state budgets. Usually, however, such costs are experienced in the short to medium term until the completion of the reform, while allowing subsidies to continue would lead to greater costs over the long term and the continuation of distorted markets (IEEP et al., 2007).

It is easier to implement a reform when there is more confidence in the markets and from the public in new economic activities. The rationale for the maintenance of inefficient subsidies and industries becomes weak when the economic outlook is bright (IEEP et al., 2007).

\section{Reform of coal subsidies in the United Kingdom}

\section{Type of subsidy and proposed reform}

From 1957, British electricity generators were required to purchase a given quantity of British coal at set prices, but were allowed to pass the costs onto consumers (Steenblik and Coroyamakis, 1995; IEEP et al., 2007). In 1990 the UK government renegotiated the agreement with British Coal to introduce a gradual decline over three years in guaranteed price and quantity purchased of British coal (IEEP et al., 2007).

\section{Drivers of subsidy reform}

Reforms had been attempted throughout the 1960s and 1970s however a lack of commitment and political turnover rendered these efforts unsuccessful. By the 1990s the British coal industry had become very inefficient by world standards. The privatisation of state-owned companies by the Thatcher government, starting in the late 1970s, allowed progress to reformation. The government found reforming coal subsidies, coupled with the failure of the Miner's Strikes in the mid-1980s, to be an effective way of reducing the power of the broader British trade unions, which had strong political power at the time (IEEP et al., 2007). 


\section{Results and key factors affecting the outcome}

Subsidies were removed in the mid-1980s, there were extensive mine closures, and the UK has since maintained a 'more or less' competitive coal industry (IEEP et al., 2007). In 1999, however, the UK government imposed a moratorium on the construction of new gas-fired power stations in order to protect the domestic coal industry. This moratorium was replaced in 2000 with a direct subsidy to the coal industry of GBP 100 million per annum for the next two years, allowing the elements of the coal industry with a viable future without aid to ride out temporary market problems. In 2002, the government agreed to an investment aid package for the remaining coal mines in a bid to allow the British coal industry to compete in the reformed electricity market and to create or safeguard jobs within socially and economically disadvantaged areas (Europe Economics et al., 2006).

In 2005, the rate of total unemployment was higher than the national average in seven of the ten local authority areas in which coal pits had been shut down between 1995 and 2005. But the gaps were narrow; in none of these cases were the total or male unemployment rate was more than $1 \%$ above the national average (Europe Economics et al., 2006).

The miner's strike of 1984-85 weakened the British trade union movement, as it was not effective at stopping the government plan to reform the sector. Strong political will managed to drive the reform through (IEEP et al., 2007).

The negative local and national economic situation was not a positive factor in the reforms. Coal-mining jobs in the coalfields of England and Wales accounted for about a quarter of all male jobs located in these areas. A 1981 census reported that there were 160000 unemployed within these areas, before the main pit closures began. Nationally, the UK underwent two recessions in 1980 and the early 1990s, particularly affecting the inefficient and unproductive manufacturing sector (IEEP et al., 2007).

Government aid to those entering unemployment from the coal-mining sector was focused on creating an enabling environment for the development of alternative economic activities in mining areas, rather than a severance package. This helped increase support to the reform and maintain economic growth in otherwise disadvantaged areas (IEEP et al., 2007).

\section{Key lessons from the subsidy reform}

A key lesson from the UK experience is that coupling the reform with measures to stimulate economic development, and therefore create new job opportunities in areas where industrial activities are to be scaled down or closed, can increase support to the reform and foster economic growth (IEEP et al., 2007).

Economically, although the local mining areas had been initially affected badly by the mine closures, by 2004, some $60 \%$ of jobs lost from the coal industry in the early 1980 s had been replaced by new non-coal jobs for men within the same area. Further, the pace of non-coal male jobs appears to be accelerating, with the number of non-coal jobs held by men increasing in the three years between 2001 and 2004 by almost as much as in either of the previous two decades (IEEP et al., 2007). 


\section{Reform of subsidies to coal mining in Spain}

Type of subsidy and proposed reform

In the 1980s the Spanish coal industry was heavily dependent on the energy supply industry and contracts it had made with governments. This enabled its expansion when the rest of the European coal industry was in decline (Europe Economics et al., 2006). Between 1994 and 2005 the EU authorised EUR 12.9 billion in aid to Spain in order to provide operating aid to maintain access to coal reserves and support for reducing coal mining activity (Europe Economics et al., 2006).

The energy market was liberalised in 1998 with the introduction of a long-term restructuring plan. Minimum quotas for Spanish coal continued, but power companies were allowed to contract directly with mining companies for the amount and price under their quota, leading to competition between the individual companies (Europe Economics et al., 2006). Power companies continue to have an obligation to purchase fixed quantities of domestic coal until the year 2012 as part of a subsidy agreement (IEA, 2009a).

\section{Results and key factors affecting the outcome}

While the private sector dominates domestic coal production (over 2 million tonnes a year), the state-owned sector is still significant and employs about one-third of those working in the industry (Europe Economics et al., 2006). In 2008, coal provided around one-quarter of total electricity generation in Spain, with domestic coal making up 8\% of the mix (IEA, 2009).

Employment in the coal mining sector fell nationally from 26000 in 1995 to 8200 in 2005, with certain areas being affected more than others. Notably, the region of Asturias saw over 10000 job losses in the coal industry and, in the region of Castilla y Leon, nearly 6000 jobs were lost. The proportion of unemployed who have been out of work for over twelve months is much higher in these areas than the national average. Elsewhere the rate of male unemployment and the proportion of unemployed who have been out of work for over twelve months is generally close to the national average, with unemployment in Aragon even being well below the national average (Europe Economics et al., 2006).

The Spanish hard coal sector is still dependent on subsidies to be competitive with imported coal. In 2004, the average cost per tonne of Spanish coal varied from EUR 82 to EUR 519, depending on the quality and source of the coal, while in the same year imported coal cost just USD 56 per tonne, including transport costs (Europe Economics et al., 2006; IEA, 2009). Since then, the imported price of steam coal has more than doubled, reaching almost USD 130 per tonne in 2008 (IEA, 2009).

Operating aid to coal mines is gradually declining from EUR 503 million in 2005 to EUR 450 million in 2007, but these figures remain considerable for an industry with less than 7000 miners (IEA, 2009a).

Coal made up 34\% of the fuel mix for electricity generation in 2002 but by 2005 the development of Gas Combined Cycles plants had reduced this mix to $28 \%$. Domestic coal also fell from $28 \%$ of the mix to just $9 \%$ (Europe Economics et al., 2006). 


\section{Reform of subsidies to hard coal mining in France}

\section{Type of subsidy and proposed reform}

Subsidies were given from the French Government, partly via the special fund SOFIREM (Société Financière pour favoriser l'Industrialisation des Régions Minières) to promote investment in the mining regions, retrain workers and encourage entrepreneurship, and to support the establishment of new businesses, industrial zones and entities responsible for local economic development. Between 1971 and 2000, the state spent around EUR 35 billion on restructuring the coal sector and $\mathrm{CdF}$ (Charbonnages de France) accumulated EUR 5.5 billion of debt to which could be added EUR 7.7 billion of "special agreements" for its staff, such as free housing and transportation (Laan, Beaton and Presta, 2010).

Preliminary OECD estimates, based on IEA data and French budget documents, indicate that total government funding to the sector amounted to EUR 975 million in 2000 and EUR 972 million in 2005. While aid to cover operating losses represented $34 \%$ of the total in 2000 , this share had decreased to $3 \%$ in 2005. In 2007, the CdF fund was liquidated and subsidies to the sector were largely stopped. (IEA, 2001 and 2002; CdF, 2006; French Senate, undated.)

After a gradual reduction ${ }^{28}$ of coal production starting in the early 1960s, an agreement (pacte charbonniere) was reached in 1994 to close all remaining coal mines. This was combined with extensive measures to promote alternative economic activity in the affected regions and longlasting measures to protect the interests of the former miners. According to the agreement, former miners were guaranteed employment with $\mathrm{CdF}$ until the age of 45 , when those with at least 25 years of service became eligible for a "leave", during which they would receive $80 \%$ of their final working salary until retirement (Laan, Beaton and Presta, 2010)

\section{Drivers of subsidy reform}

In addition to European competition legislation, the major drivers of the reform were budgetary considerations and a reduced perceived "need" to secure "energy independence" via coal mining due to an expansion of nuclear energy capacity.

\section{Results and key factors affecting the outcome}

While coal was still a crucial source of energy at the start of the reform, the last French coal mine was closed in 2004. However, after a reform lasting many decades, the ANGDM, the Agence Nationale pour la Garantie des Droits des Mineurs, still provides social support to over 200000 people. Its activities require state support of around EUR 700 million a year, an amount that will decline over time as former miners pass away (Laan, Beaton and Presta, 2010).

The (costly) expansion of nuclear-based electricity generating capacity and the generous provisions offered to the former miners helped making the closure of all the coal mines possible. 


\section{References}

Asian Development Bank (2009), Energy Policy, Asian Development Bank, June.

Baig T., A. Mati, D. Coady and J. Ntamatungiro (2007), Domestic Petroleum Product Prices and Subsidies: Recent Developments and Reform Strategies, IMF Working Paper WP/07/71, Washington DC.

Berg, H., Burger, A., \& Thiele, K. (2008), Environmentally Harmful Subsidies in Germany Dessau, Dessau-Roßlau.

CdF (Charbonnages de France) (2006), Rapport d'activité 2005, Charbonnages de France, available at www.charbonnagesdefrance.fr/IMG/pdf/ra_activite_2005.pdf.

Europe Economics (2006), Evaluation of State aid for the Coal Industry, A report by Europe Economics and Fraunhofer ISI with BSR Sustainability and the Krakow Institute for Sustainable Energy for the European Commission DG for Energy and Transport, http://ec.europa.eu/energy/coal/studies/coal_en.htm

French Senate (undated), Web-site of the French Senate, available at www.senat.fr/rap/104-074311/104-074-3115.html.

Hale, T. N. (2008), “Transparency, accountability and global governance”. Global Governance, 14.

Hamid, Jalil (2008), Malaysia PM faces bigger protest, dissent over fuel, 12 June, Reuters.

IEA (2001), Coal information, 2000 edition, IEA/OECD, Paris.

IEA (2002), Coal information, 2001 edition, IEA/OECD, Paris.

IEA (2007), Energy Policies of IEA Countries Germany 2007 Review, OECD/IEA, Paris.

IEA (2008), Energy Policy Review of Indonesia Paris, France.

IEA (2009a), Energy Policies of IEA Countries Spain 2009 Review, OECD/IEA, Paris.

IEA (2009b), Energy Prices and Taxes: Quarterly Statistics, OECD Publishing, 2001.

IEEP et al. (2007), Reforming Environmentally Harmful Subsidies, Final report to the European Commission's Environment Directorate, March 2007, UK/Belgium.

Laan, Tara, Christopher Beaton and Bertille Presta (2010), Strategies for Reforming Fossil-Fuel Subsidies: Practical lessons from Ghana, France and Senegal, Global Subsidies Initiative of the International Institute for Sustainable Development, Geneva, available at www.globalsubsidies.org/files/assets/strategies_ffs.pdf. 
OECD (2009), The Economics of Climate Change Mitigation: Policies and Options for Global Action Beyond 2012, OECD, Paris.

Suharmoko, Aditya (2010), Fitch ups RI ratings as economy strengthens, 26 January, The Jakarta Post.

Suwala (2010), Lessons Learned from the Restructuring of Poland's Coal-Mining Industry, Global Subsidies Initiative (GSI) of the International Institute for Sustainable Development (IISD), Geneva, Switzerland.

United Nations Foundation (2003), Energy Subsidies: Lessons Learned in Assessing their Impact and Designing Policy Reforms Geneva.

UNEP (2008), Reforming Energy Subsidies, Division of Technology, Industry and Economics. Paris. 


\section{Annex 3: General Equilibrium Analysis: An Egyptian case study (prepared by OPEC)}

An illustration of a general equilibrium analysis exercise can be viewed in a recent paper by Abouleinein et al. (2009), which examines the hypothetical impact of phasing out subsidies of energy products in Egypt over the short- to medium-term. The study uses a Computable General Equilibrium (CGE) model; a macroeconomic framework that takes account of dynamic effects and one that represents the standard tool of empirical economic analysis used by policy analysts.

The model allows for an assessment of both the direct impacts on the economy that are likely to occur through factors such as changes in the price level and the government budget, as well as what can be described as the 'second-round' indirect effects that are likely to spread through other economic variables such as investment and the sectoral composition of production. Households are also disaggregated according to expenditure level, so the impact of subsidy removal on poor households can be analyzed.

\section{Background}

From 1991-2004, domestic Egyptian petroleum product prices were kept almost constant, after when the government increased the prices of some products. However, the paper stresses that energy pricing policies are not clearly documented in Egypt and there is no officially published data on the cost structure of petroleum. Based on the unofficial estimates of the actual domestic cost of petroleum products, it is estimated that subsidies on energy petroleum products in Egypt increased from around LE40bn (US\$7bn) in 2005/06 to LE 60bn (US\$10.8bn) in 2007/08. These estimates are based upon domestic costs rather than world prices. The paper argues that using the latter produces unstable estimates and ignores the different social and economic circumstances between countries. In support of this approach, a report by the World Energy Council (2001) is cited, which highlights the limitations of the opportunity cost methodology. However, the paper does note that the correlation coefficients between domestic costs and world prices are more than 99 per cent for all petroleum products.

A breakdown of the shares of domestic price and subsidy for different petroleum products in Egypt are shown in Chart 1. Comparing these estimates with data on consumption patterns, the paper finds that diesel oil receives the highest share of subsidies at 39.1 per cent, although it accounts for only 19.2 per cent of total consumption. Natural gas has the highest share in consumption at 42.6 per cent, but receives only 20 per cent of subsidies. Liquefied petroleum gas (LPG) is very heavily subsidized at 21.8 per cent, but in terms of consumption it only represents 8.1 per cent. Fuel oil accounts for 24 per cent of consumption and 10 per cent of subsidies. Gasoline receives the smallest share of subsidies at nine per cent, being the least consumed petroleum product at six per cent of total consumption. Based on these estimates, subsidies are assigned to each petroleum product within the CGE model. 


\section{Chart 1: Ratios of domestic prices and subsidies to actual costs}

of petroleum products in $2007 / 08$

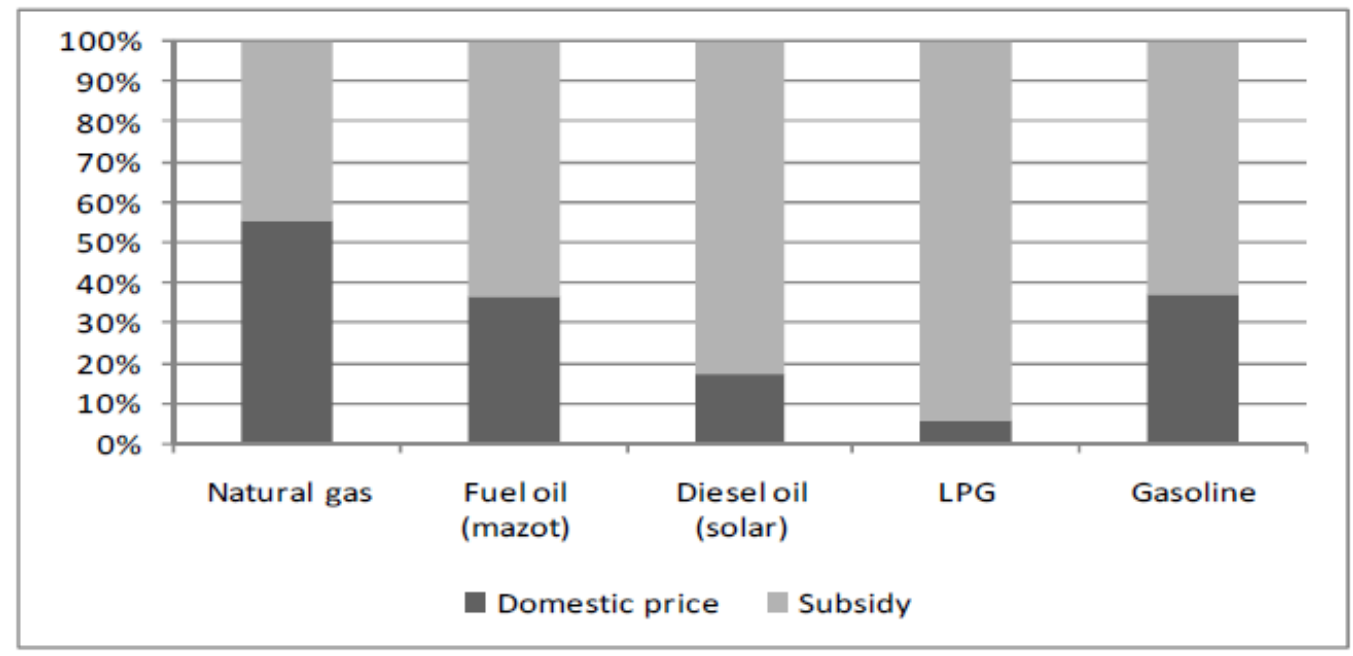

Source: Abouleinein et al. (2009)

It is calculated that the immediate removal of all subsidies would result in a sudden 36.9 per cent jump in consumer prices. This is shown in Chart 2. On a sectoral basis, electricity experiences the sharpest price increase of 59.6 per cent, although the sector's contribution to the overall increase in the Consumer Price Index (CPI) is just 1.4 percentage points. In fact, the aggregated sector of 'energy intensive industries' contributes the largest increase to the CPI, amounting to 12.9 percentage points. The paper also underscores that increasing the price of natural gas and/or fuel oil alone would affect lower expenditure groups more significantly.

Chart 2: Percentage increase in price index resulting from subsidy removal

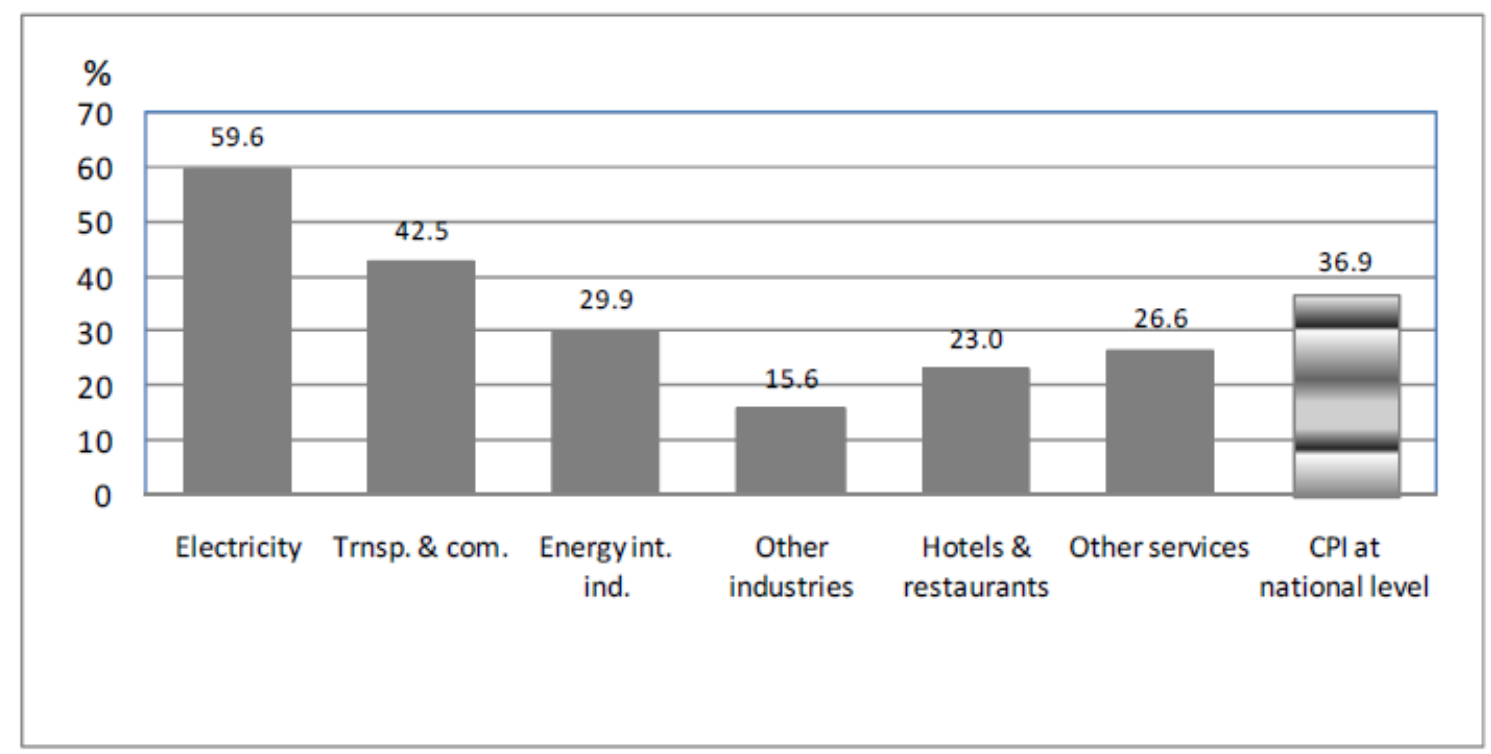

Source: Abouleinein et al. (2009) 
It is worth noting the very low estimates of the price elasticities of Egypt's petroleum products, with natural gas, LPG and gasoline at $0.078,-0.174$ and -0.294 respectively. These figures indicate rigidity in the consumption response to changes in the prices of these products.

\section{Simulation results}

The paper uses the CGE model to conduct a number of policy-related simulation experiments involving the gradual elimination of petroleum subsidies to equal actual costs. Subsidies are phased out gradually - over a five-year period - to avoid drastic consumer price increases. Impacts are assessed, with and without offsetting policy actions, which involves the use of some of the savings from subsidy removal to fund government cash transfer schemes. The results are then compared with a baseline path that assumes a continuation of current economic policies.

The elimination of energy subsidies, without any offsetting policy actions, would reduce average annual GDP growth by 1.4 percentage points over the reference period. This is of major importance as economic growth is a main pillar in reducing unemployment and poverty within the framework of sustainable development. All sectors experience a slower growth rate, but the negative affect on energy-intensive industries, electricity, services and the petroleum sectors is particularly acute. Household welfare levels across all income distributions are depressed, but rural households suffer the largest impact as LPG and diesel are their main energy sources. The prices of these two energy products witness the highest increase of around $50 \%$ and $18 \%$ per annum respectively. Overall, however, inequality is reduced, which reflects the larger welfare impact on households in the richest quintile of the distribution.

The authors also examine alternative scenarios involving either targeted or untargeted transfers that redistribute 50 per cent of the energy subsidy savings. Untargeted transfers of this magnitude still result in income losses to households at all levels of the income distribution. However, transfers targeted to the poorest two quintiles of the income distribution increase their welfare relative to what it would have been in the presence of energy subsidies. This generates a large improvement in income distribution measures. Economic growth is higher with targeted transfers compared to untargeted transfers, as a greater portion of the funds are recycled into higher consumption. While theoretically the transfer of funds to the targeted income groups is the desirable recommendation, its implementation might turn out to be very difficult, if not impossible, at least in the short-term. Particularly taking into account the inflationary effect of this policy change, this is being calculated to rise to almost $37 \% \mathrm{CPI}$, which in itself has a negative impact on the income distribution. Overall economic growth is still lower than what it would have been in the absence of the reforms.

\section{Possible policy implications}

The report underlines the importance of integrating energy policies with other policies of economic development. They should not be viewed separately. Furthermore, it stresses that adjusting energy prices and removing subsidies should not be considered as a once-and-for-all reform measure. If and when subsidies are phased out, it should be implemented gradually to avoid drastic price increases. Mitigating measures in the form of cash transfers to households to avoid a drop in their social well-being should also be considered. 


\section{References}

Abouleinein, El-Laithy and Kheir-El-Din (2009), “The impact of phasing out subsidies of petroleum energy products in Egypt", The Egyptian Center for Economic Studies.

World Energy Council (2001). "Pricing energy in developing countries", available online at http://www.regulationbodyofknowledge.org/documents/163.pdf 


\section{Annex 3: A Senegal case study (prepared by OPEC)}

The advantages of reducing and preventing deforestation are widely recognized. It is a fact that as trees grow they absorb carbon, thus maintaining forests will help limit $\mathrm{CO}_{2}$ emissions.

Limiting deforestation can help protect flora and fauna, as well as local livelihoods. And in developing countries, where many still use biomass from forests for their basic energy needs, providing options for the local population to move away from the burning of wood has major environmental, social and health benefits. ${ }^{29}$

In a United Nations Environment Programme (UNEP) report first published in 2003, a case study from Senegal underscores a number of these benefits. In the 1970s, against the background of the country's constantly rising population, as well as much concern about declining forest cover, soil erosion, local pollution and other social issues, there was much talk about the need to reduce fuelwood consumption. The report states that by the end of the 1970s this type of fuel amounted to more than 60 percent of the country's total energy consumption and about 90 per cent of household-energy needs. ${ }^{30}$

The use of fuelwood for the most basic energy needs clearly has a number of downsides. Cooking and heating with such solid fuels on open fires or stoves without chimneys leads to indoor air pollution. This places a major burden on the health of poor families in developing countries. ${ }^{31}$ Those involved in the collection of biomass - usually women and children - do so at high opportunity cost, as this process can often be very time consuming. It would clearly be more beneficial if they could use this time in education or paid employment. ${ }^{32}$ And of course the cutting down of forests has impacts both locally, for example, in regards to land degradation and potentially reducing the amount of available clean water, and globally, in terms of $\mathrm{CO}_{2}$ emissions.

It has previously been noted that households choose which energy sources to use in accordance with changes in the relative prices of different fuels. Households are traditionally depicted as moving up an 'energy ladder' as they become wealthier: on the bottom rung is biomass; then liquefied petroleum gas (LPG) and kerosene; and, at the top, is electricity. Rather than a continuous movement 'upward', most households engage in 'fuel stacking', mixing various different energy sources, often for particular services, and increasing and decreasing their use of more modern fuels as prices and household welfare dictate. The key is giving households the options to progress up the 'energy ladder'. ${ }^{33}$

In Senegal in the 1970s, the Government devised strategies aimed at reducing the impact of biomass use through inter-fuel substitution, as well as with the improved efficiency of wood stoves and charcoal kilns, and enhanced woodland management. The Country Study: Senegal ${ }^{34}$ says the authorities devoted particular attention and priority to measures favouring the intensification of domestic consumption of modern energy sources, particularly of liquefied petroleum gas (LPG), in urban areas. The study adds that Government support initially involved exemptions from customs duties on equipment connected with butane. ${ }^{35}$ In 1987, fuel subsidies were introduced on the fuel itself. And as the programme developed, cooking equipment was then subsidized.

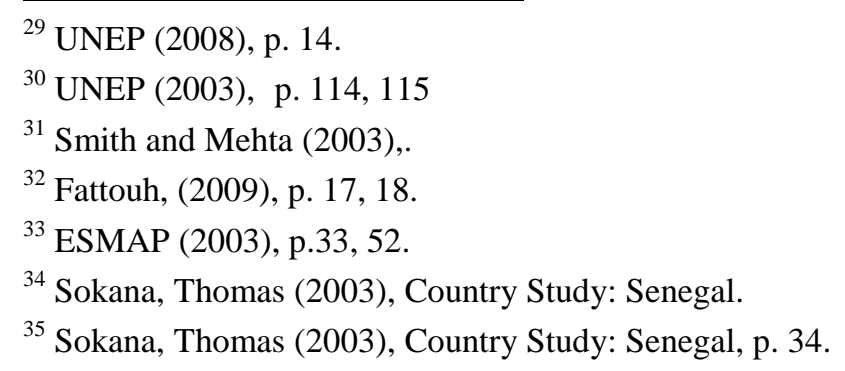


The UNEP Report and the Country Study underscore the main results: ${ }^{36}$

- Subsidies led to a significant boom in LPG consumption, which grew from less than 3,000 tonnes in 1974, to 15,000 tonnes in 1987 and nearly 100,000 tonnes by 2003.

- It noted, however, that $80 \%$ of all LPG sold in Senegal in 2003 was consumed in the capital city, Dakar. In Dakar, there was a visible decline in the deliveries of fuelwood as LPG deliveries rose. Outside of the capital, however, fuelwood consumption remained high;

- While it suggests that it is very difficult to estimate how much the growth in LPG use affected the consumption of traditional fuels, according to estimates provided by Senegal's Ministry of Energy in 2000, the growth in LPG use resulted in annual savings of about 70,000 tonnes of fuelwood and 90,000 tonnes of charcoal;

- By 2003, nearly 85 per cent of households in the capital city, Dakar, and 66 per cent of those in the other main urban areas owned LPG stoves;

- Over the years, the LPG programme, although it did not succeed in fully replacing other fuels, clearly modified household energy-use patterns in urban areas;

- From the viewpoint of the local population, subsidies improved household comfort standards and safety, and enhanced incomes; and

- From an environmental perspective, it helped relieve deforestation pressures and reduced pollution;

- The programme, however, did represent a significant financial cost.

While the results of the programme are clearly not conclusive, it is evident there are significant health, social and environmental benefits in switching away from traditional biomass towards more modern energy services. It can help reduce local pollution, enhance the standards of living of the local population and reduce deforestation.

\section{References}

ESMAP (2003), Household Fuel and Energy Use in Developing Countries - A Multicountry Study, Washington D.C.Fattouh, Bassam (2009), Fossil Fuel Subsidies: Issues, Impacts and Options for Reform

Smith R. Kirk, Sumi Mehta (2003), The burden of disease from indoor air pollution in developing countries: comparison of estimates.

Sokana, Thomas (2003), Country Study: Senegal

UNEP (2003), Energy Subsidies: Lessons learned in assessing their impact and designing policy reforms, Division of Technology, Industry and Economics, Paris.

UNEP (2008), Reforming Energy Subsidies, Division of Technology, Industry and Economics, Paris.

${ }^{36}$ UNEP (2003), p. 113-120, Sokana, Thomas (2003), Country Study: Senegal.. 


\section{Annex 3: Case Studies evidence from Developing Countries (prepared by the World Bank)}

In a forthcoming publication the World Bank (2010) a selected a representative sample of case studies, based on a number of criteria, including the country level of development (and energy consumption), developing country region, energy security (net import/export of energy and subsidized fuel (kerosene, gasoline, diesel, electricity, natural gas, LPG), as reported in Table 1 below.

Table 1 Sample Selection of Case Studies

\begin{tabular}{|c|c|c|c|c|c|c|}
\hline & AFR & ECA & EAP & LAC & MENA & SAR \\
\hline $\begin{array}{l}\text { Low } \\
\text { Income }\end{array}$ & $\begin{array}{l}\text { Ghana } \\
\text { Nigeria }\end{array}$ & & & & Yemen & \\
\hline $\begin{array}{l}\text { Lower- } \\
\text { Middle } \\
\text { Income }\end{array}$ & & $\begin{array}{c}\text { Armenia } \\
\text { Azerbaijan } \\
\text { Moldova }\end{array}$ & Indonesia & & $\begin{array}{l}\text { Egypt } \\
\text { Iran } \\
\text { Morocco } \\
\text { Jordan }\end{array}$ & $\begin{array}{c}\text { India, } \\
\text { Pakistan }\end{array}$ \\
\hline $\begin{array}{l}\text { Upper- } \\
\text { Middle } \\
\text { Income }\end{array}$ & & $\begin{array}{c}\text { BiH } \\
\text { Turkey }\end{array}$ & Malaysia & $\begin{array}{c}\text { Argentina } \\
\text { Dominican Rep. } \\
\text { Peru } \\
\text { Mexico }\end{array}$ & & \\
\hline $\begin{array}{l}\text { High } \\
\text { Income } \\
\text { non OECD }\end{array}$ & & & & Chile & & \\
\hline
\end{tabular}

Source: World Bank (2010)

Note: Selected sample based on income, region, energy net export (in red)

Selected lessons from this set of case studies (for more details see World Bank, 2010) are reported below. Lessons are drawn on cases where subsidies have been used to increase access, to switch towards cleaner fossil fuels. Finally, cases where inefficient fossil fuel subsidies were removed supported by social safety net schemes are also included.

- Off grid electrification subsidies, as those used in Chile and Peru, can be justified to extend access and address the problem of affordability. Operating costs for isolated mini grid connection are much higher than those for grid electrification. If the true costs were reflected in the tariffs people living in remote rural areas would pay much more than those in urban areas.

- In the case of first time connection to natural gas or electricity or switch towards cleaner fossil fuels such as LPG, a one off subsidies can be considered acceptable. In the case of Morocco such subsidies were used as an incentive for consumer to switch from biomass to cleaner sources of energy. Several lessons emerge also in the case of LPG subsidies. Once in place, removal of subsidies may prove politically challenging and give rise to social 
unrest, as in the case of Morocco. Also in the case of India recommendations of a panel led by former Planning Commission member Kirit Parikh in 2008, including the increase in retail prices of kerosene and liquefied petroleum gas by Rs6 per litre and Rs100 per cylinder were not followed. Collusion between distributors can also occur, as in the case of Argentina, where the subsidies is captured by the fuel distributors rather than the households. In the latter case a cap on retail prices or monitoring on the fuel distributors may be used to mitigate risks of collusion.

- Geographic subsidies have been less effective that subsidies based on proxy means testing. In the case of Dominican Republic which has been using geographic subsidies since 2001 industries and households were all receiving the same rate of subsidization, resulting in energy excessive consumption and also providing perverse incentives for business to move towards areas with subsidies. Proxy means testing has been successfully used in the Chilean case of Ficha CAS, which has proved to be particularly cost effective with the administrative costs amounting for just $1.2 \%$ of the total benefits distributed through the system, as it allowed to spread fixed administrative cost of the needed social database system across several programs beyond energy. Proxy means have also been also recently used in the case of the Benazir Income Support Program in Pakistan to mitigate the impact of oil, natural gas and diesel price increases since 2008. More sophisticated targeting, including the use of unconditional cash transfers proved to be successful in Indonesia, with the poorest decile receiving $21 \%$ of the benefits. 


\section{Annex 4: The impact of energy subsidies removal on the poor (prepared by the World Bank)}

A number of empirical studies have used computable general equilibrium models (CGE) to model the welfare impact of removal of energy subsidies. The benchmark dataset needed for a CGE model is generally specified in the form of a "social accounting matrix" or SAM. The construction of an accurate SAM is challenging. The raw materials take the form of the National Accounts, input-output tables, household surveys, and a variety of other data. A number of cautionary remarks need to be made. Concepts and definitions differ between data sources. And even after adjustments have been made to make definitions consistent, the estimates for what are conceptually the same totals coming from different sources will generally differ.

- ESMAP (2004) uses a CGE model to simulate the effects of the removal of electricity subsidies in Mexico over the period 2000-2015. The overall effects at the macroeconomic level were small-with GDP, exports, imports, and employment all experiencing small declines. Welfare decreased for all income classes, but the poor were affected most because electricity subsidies were more important in proportionate terms for the lowerincome households.

- Oktaviani et al. (2007) use a CGE model to analyze the elimination of fuel subsidies in Indonesia, which occurred in three stages over the period 2000-05 (prices were increased by $12 \%$ in $2000,30 \%$ in 2001 and $29 \%$ in 2005). They conclude that the short to mediumterm macroeconomic performance of the economy was impaired by the removal of the subsidies, due to a reduction in household incomes and increase in domestic prices. Furthermore, the reduction of fuel subsidies increased the overall incidence of poverty in the Indonesian economy from $8.9 \%$ to $12.9 \%$ of the population, with rural areas worst affected. On the other hand, the authors note that there is little difference in terms of inequality over the period; declines in household incomes were fairly uniform across income groups. The authors conclude that the government should offset the impact of subsidy removal with measures to compensate households, but they question whether the means exist to distribute these funds effectively.

- Manzoor et al. (2009) uses a CGE/MPSGE based on the specific modeling of the energy sector in Iran. The specific modeling of the implicit subsidies is based on the assumption of an implicit rent payment to the specific government ownership of mineral resources in oil extraction and gas. Their study shows that removing energy subsidies results in shrinking of output, the reduction in urban and rural welfare respectively by $13 \%$ and $12 \%$ and also hyperinflation.

- Abouleinein et al. (2009) studied the impact of phasing out fuel subsidies in Egypt over a five-year period. Using a CGE model, it shows that the elimination of energy subsidies, without any offsetting policy actions, would reduce average annual GDP growth by 1.4 percentage points over the reference period and depress the welfare levels of households at all levels of the income distribution. Inequality is reduced, however, reflecting the larger welfare impact on households in the richest quintile of the distribution (see also Annex 3).

It should be noted that some CGE models, do not account for the impact of the redistribution of the amount of money coming from subsidy removal to the poor. If subsidies are better targeted or the money of is used directly through cash transfer, the poor may gain from subsidy removals.

Table 1 summarized the analysis based on Poverty and Social Impact Analysis that has been implemented by the Bank and other authors to simulate the impact of subsidies removal on increase in energy expenditure. For countries where household surveys were used to simulate the 
impact of subsidy removal on the bottom and top quintiles are also reported. The results bear important consideration as overall the impact of subsidies removal was more important for the poorest household (bottom quintile income group) than for the top quintile income group).

Table 1

\begin{tabular}{|l|l|l|l|}
\hline Country & Energy Subsector & $\begin{array}{l}\text { Effect on bottom quintile } \\
\text { income group }\end{array}$ & $\begin{array}{l}\text { Effect on top } \\
\text { quintile income } \\
\text { group }\end{array}$ \\
\hline Armenia & Utilities & $9 \%$ increase in expenditure & $\begin{array}{l}3 \% \text { increase in } \\
\text { expenditure }\end{array}$ \\
\hline Bolivia & Hydrocarbon derivatives & $\begin{array}{l}5.4 \% \text { reduction in real } \\
\text { income }\end{array}$ & $\begin{array}{l}4.7 \% \text { reduction in } \\
\text { real income }\end{array}$ \\
\hline $\begin{array}{l}\text { Egypt, Arab } \\
\text { Rep. of }\end{array}$ & Fuel, Kerosene, Gas, LPG & $7.7 \%$ reduction in income & $\begin{array}{l}4.1 \% \text { reduction in } \\
\text { income }\end{array}$ \\
\hline Ghana & Petrol, Kerosene, LPG & $9.1 \%$ reduction in income & $\begin{array}{l}8.2 \% \text { reduction in } \\
\text { income }\end{array}$ \\
\hline Jordan & Fuel & $\begin{array}{l}5.4 \% \text { reduction in real } \\
\text { income }\end{array}$ & $\begin{array}{l}4.1 \% \text { reduction in } \\
\text { real income }\end{array}$ \\
\hline Madagascar & $\begin{array}{l}\text { electricity, gasoline, diesel, } \\
\text { and kerosene }\end{array}$ & $\begin{array}{l}3.2 \% \text { increase in } \\
\text { expenditure }\end{array}$ & $\begin{array}{l}2.3 \% \text { increase in } \\
\text { expenditure }\end{array}$ \\
\hline Mali & $\begin{array}{l}\text { Gasoline, Diesel and } \\
\text { Kerosene }\end{array}$ & $\begin{array}{l}1.8 \% \text { increase in } \\
\text { expenditure }\end{array}$ & $\begin{array}{l}1.9 \% \text { increase in } \\
\text { expenditure }\end{array}$ \\
\hline Moldova & $\begin{array}{l}\text { Electricity, Central Heat, } \\
\text { Central Gas, LPG }\end{array}$ & $\begin{array}{l}2.2-6.9 \% \text { increase in } \\
\text { expenditure }\end{array}$ & $\begin{array}{l}2.6-7.7 \% \text { increase in } \\
\text { expenditure }\end{array}$ \\
\hline Sri Lanka & Fuel & $\begin{array}{l}2.9 \% \text { reduction in real } \\
\text { income }\end{array}$ & $\begin{array}{l}2.2 \% \text { reduction in } \\
\text { real income }\end{array}$ \\
\hline Tajikistan & Electricity & $\begin{array}{l}16 \% \text { increase in } \\
\text { expenditure }\end{array}$ & \begin{tabular}{l}
- \\
\hline
\end{tabular} \\
\hline
\end{tabular}

\section{References}

Abouleinein, El-Laithy and Kheir-El-Din (2009), "The impact of phasing out subsidies of petroleum energy products in Egypt", The Egyptian Center for Economic Studies.

Andriamihaja, N. and G. Vecchi. 2007. "An Evaluation of the Welfare Impact of Higher Energy Prices in Madagascar." Africa Region Working Paper Series 106, World Bank, Washington, DC.

Coady, D., M. El-Said, R. Gillingham, K. Kpodar, P. Menas, and D. Newhouse. 2006. "The Magnitude and Distribution of Fuel Subsidies: Evidence from Bolivia, Ghana, Jordan, Mali, and Sri Lanka." IMF Working Paper WP/06/247. International Monetary Fund, Washington, DC.

ESMAP. 2004. Energy Policies and the Mexican Economy. Technical Paper 047, January 2004. Washington, DC: World Bank.

Kpodar, Kangni. 2006. "Distributional Effects of Oil Price changes on Household Expenditures: Evidence from Mali." Working Paper WP/06/91, International Monetary Fund, Washington, DC. 
Manzoor, Davood Asghar Shahmoradi, Iman Haqiqi. 2009 An analysis of Energy Price Reform: A CGE Approach, Imam Sadiq University and Ministry of Energy, Iran

Oktaviani, R, Hakim, D.B, Siregar, Sahara. 2007. Impact of a Lower Subsidy on Indonesian Macroeconomic Performance, Agricultural Sector and Poverty Incidences: A Recursive Dynamic Computable General Equilibrium Analysis. MPIA Working Paper 2007-2008 